\title{
Arbor
}

\section{La más alta ocasión (Relatos)}

\author{
José Ignacio de Arana Amurrio
}

Arbor CLXXVIII, 703 (Julio 2004), 481-570 pp.

\section{La más alta ocasión}

(Primer Premio IX Concurso «TRIBUNA MÉDICA» de cuentos)

A pesar de que ya era de noche y soplaba un vientecillo terrano, el aire seguía oliendo a pólvora y a madera quemada. Quizá no fuese cierto; quizá es que esos olores había impregnado de tal forma la nariz de los hombres que éstos seguían percibiéndolos con claridad cuando ya hacía muchas horas que había terminado la batalla. Allí en Petala, la pequeña isla al norte del golfo de Lepanto, dispuso Don Juan que se desembarcara a los heridos y enfermos de su Armada para recibir la asistencia de los médicos y de los cirujanos. Y Don Dionisio Daza Chacón, cirujano mayor de las galeras de España, llevaba ya casi tres días sin dormir, mojándose de vez en cuando la cara y la cabeza con agua fría para mantenerse, aun así a duras penas, despejado. Corrían voces por el improvisado campamento de tullidos y dolientes que hablaban de ocho mil cristianos muertos en la jornada y que los turcos habrían perdido en proporción de tres a uno de sus hombres: una matanza extraordinaria. Como extraordinario era el número de los que ahora estaban tendidos en yacijas de campaña, cuando no en el puro suelo, o de los que iban de un lado a otro apoyados en improvisadas muletas hechas con astiles rotos de picas y alabardas o con las horquillas de los mosquetes. La nariz de Don Dionisio ya no distinguía entre los mil olores del ambiente: al relente de la noche parecía, sí, oler a pólvora y a humo de incendios, pero en el interior de los tenduchos de lona y velas desgarradas, olía a carne chamuscada por las cauterizaciones y a podredumbre de miseria humana en su más extrema condición. 
Más de cincuenta cirujanos se afanaban de acá para allá atendiendo a los hombres; otros tantos clérigos consolaban a unos, daban la unción a los moribundos y procuraban hacer oídos sordos a los exabruptos y blasfemias que salían de la sala donde se amputaban miembros, se quemaban muñones y se cosían heridas espeluznantes. Los que caían en manos de Don Dionisio tenían más suerte. El Doctor Daza hacía mucho tiempo que abandonó esas prácticas y utilizaba una técnica de su invención para amputar los miembros: «primero contenía la sangre con ligaduras y cauterizando sólo las bocas de las arterias, después de hecha la amputación, limpiamente, con un cuchillo muy bien afilado, el hueso lo cortaba con una sierra de hacer peines muy finos. La cura final la hacía con una mezcla de clara de huevo, sangre de drago, bol arménico y acíbar». Esto le ocasionó quebraderos de cabeza y más de un disgusto con sus colegas que seguían propugnando la cura ígnea; otro tanto le ocurrió cuando defendió públicamente que las balas no tenían efectos ponzoñosos y que, por tanto, no era necesario someter al paciente a arriesgadas intervenciones para extraérselas, sino que valía más la pena dejarlas alojadas en el cuerpo siempre que no fuera en un lugar de riesgo vital. Todas aquellas ideas suyas no las había aprendido durante sus años de estudio en Salamanca; fue después, en sus años de práctica guerrera junto al Emperador Carlos de feliz memoria y luego en las tropas de su hijo Don Felipe el Prudente; ahora seguía actuando así pero no lograba que ningún otro cirujano le secundara. Algún día, se consolaba a sí mismo en los ratos de abatimiento, habría de escribir sobre todas esas cosas y quizá entonces alguien le hiciera caso, algún estudiante de su Salamanca o de Valencia o de aquellos hospitales de Guadalupe a donde iban a hacer sus primeras armas quirúrgicas los cirujanos recién licenciados y sin posibles para ejercer a la sombra de los maestros consagrados. Pero por el momento se conformaba con el íntimo regusto de ver cómo los heridos que él asistía mejoraban más deprisa que los otros y morían menos y quedaban con menores invalideces.

Si bien la máxima de toda su vida médica había sido, y seguía siendo, «cura del mismo modo a los pobres que a los ricos y a los esclavos como a los libres», allí en Petala tenía por fuerza que atender sólo a unos cuantos y el mismo Don Juan de Austria le había encomendado desde el primer momento el cuidado de los nobles y de los oficiales. Aun así no daba a basto, tantos eran los heridos de una y otra condición. El Capitán General en persona solía aparecer varias veces al día por el campamento, acompañado de sus generales y almirantes, destacando su extrema juventud entre Bazán, Doria o Requeséns. En la cara de Don Juan, atezada de sol y de humo, resaltaban los azules ojos que brillaban como estrellas, saliendo por ellos toda la fuerza que animaba su espíritu en aquellas 
jornadas de gloria. Para todos tenía palabras de consuelo y de alabanza; se agachaba a besar la frente de algunos soldados que sirvieron en su galera capitana y sus manos estrechaban las que se le ofrecían, temblorosas de fiebre unas, otras entablilladas, tímidas algunas, firmes y orgullosas las más. Especial afecto demostraba con los galeotes cristianos liberados del remo turco y les prometía una parte en el botín alcanzado del enemigo que los había subyugado.

Don Dionisio Daza Chacón asistía a todo aquello desde su cansancio infinito, resistiendo el dolor de todos y cada uno de sus huesos y la terrible pesadez de los párpados que pugnaban por cerrarse en busca de un reposo que parecía no iba a llegar nunca. Pero el hermano del Rey, aquel jovencísimo general en quien parecía resucitar el ímpetu de su padre el César Carlos, no permitía el sosiego a quienes tenían una misión que cumplir. De continuo preguntaba por unos y otros, se interesaba por la gravedad de una herida y por el pronóstico y repetía a cada paso:

- Cuidádmelos bien, Don Dionisio, que hombres como éstos no ha de volver a conocer la Historia.

Y Don Dionisio volvía a la tarea. Emplastos, sajaduras, tisanas y, cuando no había otra cosa que hacer, buenas palabras, un gesto cariñoso, sentarse unos minutos junto al hombre que sufre y delira, rezar con ellos y, si llegaba el final, cerrar los ojos del que ya descansaba -ifeliz él!para siempre. ¿Cuándo terminaría aquel guirigay de lamentos y de gritos, de manifestaciones de dolor humano que apenas sí se atenuaban con las entrecortadas voces de júbilo con que los heridos saludaban el paso del Generalísimo Don Juan? Para él, cirujano de guerra que tuvo su bautismo de pólvora en el sitio de Landresi a las órdenes de Don Pedro de Guzmán y que había recorrido, con su caja de instrumentos quirúrgicos, desde la vega granadina ardorosa de morisma levantisca hasta los confines del Mediterráneo como médico de laśgaleras reales, apenas existiría, si acaso, una breve pausa de paz. Los reinos de Don Felipe eran tan extensos que siempre habría ocasión de pelear con sus enemigos y trabajo para el cirujano. Echaba de menos una temporada en la tierra firme de España tras tanto tiempo de navegar en sus barcos; quizá en su Valladolid natal o, por qué no, en la corte de Madrid, donde se daban cita los más prestigiosos médicos del reino. Pero no; tendría que esperar a que sus ojos no pudieran ya seguir el curso de una herida ni sus manos empuñar el cuchillete o la sonda; sólo entonces se daría un descanso a sí mismo, porque su vocación fue siempre estar en primera línea de lucha contra el dolor y el sufrimiento físico de sus semejantes. 
En estas meditaciones andaba el Doctor Daza, sin atreverse ya ni siquiera a sentarse para no caer dormido, cuando una voz tronante a su espalda le espabiló con brusquedad.

- ¡Dionisio! ¡Dionisio Daza, amigo mío!

Se volvió con más rapidez de la que esperaba él mismo y se encontró de bruces con una figura que, a la luz vacilante de las antorchas, parecía la de un gigante.

- ¡Gonzalo Gil! ¡Válgame Santa María! ¿Qué hacéis vos por aquí, viejo matasanos?

A los dos hombres, compañeros de estudios en la universidad salmantina y pupilos ambos del mismo dómine en el barrio estudiantil de la ciudad castellana, se les llenaron a la vez los ojos de lágrimas.

- He estado embarcado en las galeras venecianas del almirante Barbarigo, a quien Dios tenga en su seno. Luché, pues, en Lepanto hace dos días como hicisteis vos. ¡Dios mío, cuántos años, Dionisio!

- Me parece que casi veinte que os perdí la pista.

- Yo a vos no os la perdí, que siempre sabía por alguien de vuestras andanzas con las tropas del Emperador y luego del Rey. Supe también que estabais en esta memorable jornada y desde que pusimos pie en tierra ando buscándoos cuando el trabajo me lo permite. Este encuentro colma mi felicidad.

Gonzalo Gil descolgó de su hombro un mediano pellejo, renegrido de años y manoseos, y ofreció del contenido a su amigo. Era un vinillo aloque, de áspero sabor y fácil tragar que serviría de nexo, en su vaivén de mano en mano, a la conversación de los dos médicos. Los temas surgían como torrentes y arrebataban ora risotadas, ora lágrimas, o las dos cosas a la vez de aquellos hombres que, de pronto, por la magia del encuentro y los recuerdos, habían olvidado el cansancio sobrehumano que poco antes les hacía arrastrarse por entre sus pacientes. En una de las revueltas de la bota, Gil dijo a su amigo

- Quisiera pediros un favor que, como os conozco, sé que no habréis de negarme.

- ¿Qué es ello? Si está a mi alcance, está hecho.

- Esto es. Se trata de un herido de mi galera, La Marquesa. No es noble ni oficial sino soldado de a pie aunque muy bravo. Os hablo de él porque a poco de embarcarme vino a verme a mi estancia; se trata, yo no le reconocí, del hijo de un Rodrigo Cervantes, cirujano de medio pelo en Alcalá de Henares, que me ayudó un tiempo cuando 
paré en esa ciudad en mi peregrinar por las tierras españolas. Él sí se acordaba de mí como de quien en sus pocos años veía cual un hombre de lustre junto a su padre. El caso es que durante la pasada batalla sufrió dos heridas, una en el pecho que es poca cosa, y otra en el brazo izquierdo, la cual se me antoja de peor cariz; a todo esto se suma una calentura que, teniéndole durante la travesía tendido en cama, no le impidió subir a la cubierta para luchar como el primero, pero que ahora le acongoja por demás. Vos, Dionisio, sois, que así me consta, el mejor cirujano de esta campaña y quisièra que le atendieseis porque mi ciencia no alcanza y es hombre en quien quiero honrar la grata memoria que guardo de su padre y de mis años mozos.

- Juntos aprendimos esta ciencia, amigo Gonzalo, y tanto sabréis vos como yo. Pero, jea!, llevadme a él y veamos qué se puede hacer.

Atravesaron un par de círculos de hogueras donde algunos hombres jugaban al naipe y bebía a morro de grandes odres colgados de alabardas. A poco llegaron a un cobertizo de adobes y cañas al que tuvieron que entrar doblando cerviz y espaldas por lo menguado de la puerta, que descubría su prístina dedicación a majada de ganados. Dentro, a la temblorosa llama de dos teas, se adivinaba el bulto de varios jergones. Al lado opuesto de la puerta, en un trozo del recinto sin techo y sin apenas muro, derruidos los dos cualquier invierno, un hombre enjuto y barbicerrado se sentaba a la morisca sobre unos trapos viejos, quizá una capa irreconocible de puro astrada. Sus ojos reflejaban el brillo de las antorchas que parecían arder dentro de sus órbitas.

- Ojos febriles -pensó al instante el avezado Don Dionisio-. Este debe de ser el hombre.

- Mirad, Miguel -dijo Don Gonzalo agachándose hacia el personaje arrinconado-, éste es Don Dionisio Daza Chacón de quien os hablé ayer mañana. Enseñadle vuestras heridas.

- ¿Cómo estáis, caballero? -preguntó el médico de las galeras que se había puesto en cuclillas junto al herido-.

- Pues, señor -dijo Miguel con una voz que temblaba por la fiebre-, si me miro a mí mismo me veo y me encuentro como para dar el último aliento; mas si miro en derredor, pienso que esto mío es nonada.

- No es mala esa conformidad, pero ahora descubríos para que pueda examinaros. $Y$ vos, Gonzalo, acercadme esa antorcha.

El oficio de muchos años y muchos lances como aquél permitió al Doctor Daza examinar al herido en breves momentos. Sus hábiles manos palparon y percutieron, su olfato olió las laceraciones; sus ojos saltaban a 
cada instante de la zona herida a los ojos de su paciente que estaba fijos en él pero sin manifestar angustia, sólo un interés de observador que contemplara una escena ajena a su propia persona. Al acabar, el médico adoptó la postura sentada en un extremo de la capa del soldado y se dirigió a éste con lenguaje contenido y lento, como tenía por costumbre hacer con todos sus enfermos.

- Escuchad, Don Miguel. Mi opinión coincide con la de Don Gonzalo Gil. Esa herida del pecho no tiene maldad y curará en pocos días con algún apósito y sin más dolor que el propio de la encarnadura. Lo de vuestro brazo es ya otra cosa. El arcabuzazo que en mala hora os alcanzó ha hecho mella en las partes blandas y sin duda ha roto, con la carne y los tendones, las nervosidades que le dan su natural movimiento y vida. En resolución: no podréis volver a serviros de ese brazo.

La tiritera febril de Miguel, que no había cesado en ningún momento, no permitía saber si el dictamen del médico había sacudido su ánimo. La mirada de Don Dionisio escrutó nuevamente los ojos brilladores del soldado. Las primeras palabras de éste dejaron atónitos a los dos médicos.

- Decidme, señores, ¿cuánto tardarán en España en conocer los hechos de esta jornada de Lepanto? ¿Creéis que ya sabrán en Castilla de nuestra victoria?

El Doctor Daza miró con gesto de perplejidad a Gil, pero enseguida se repuso.

- No, aún no es posible. El Generalísimo Don Juan envió, al poco de concluir la batalla, varios barcos con emisarios: a su hermano el Rey, al Papa y a las Señorías de Génova y Venecia, pero aún navegarán hacia allí. Considerad que no hace tres días de los hechos. Mas, perdonadme Don Miguel. ¿Habéis comprendido lo que antes os dije de vuestra situación?

- Claro, maese Daza. Me dijisteis que seré manco de por vida. Bien está si Dios así lo dispuso. Otros muchos saldrán peor librados de la ocasión y pienso que la gloria de ésta ennoblecerá nuestras heridas y menguas ante el mundo que nos contemple mañana. Una cicatriz de Lepanto ha de valer, estad seguro buen doctor, tanto como una Encomienda en Indias. Esos barcos de que habláis navegarán aún lejos de la tierra cristiana, pero yo estoy cierto de que los hechos que aquí han sucedido no caben en los papeles de un mensajero. También sé que su noticia ha de haber volado como las aves del mar hacia tierra firme. Más o digo; el mismo sol que alumbró la 
pelea y contempló la victoria habrá llevado el mensaje en su camino a occidente y ha dos días que lo habrá gritado en España. Alguien allí lo habrá sabido entender sin esperar a que las campanas redoblen a la llegada de los mensajeros. ¿Qué decís vos?

Don Dionisio iba a contestar. Iba a decirle a aquel pobre soldado manco que no se ocupara de esos sueños sino de acomodar su vida para en adelante; le daría algún consejo y palabras de ánimo. Pero no pudo hacerlo. En ese momento alguien entró en el ruinoso edificio en su busca.

- ¡Don Dionisio! Don Juan os reclama en su Real. Acudid presto.

Se incorporó con cierta dificultad de su postura; puso su mano sobre la cabeza de Miguel y salió sin despedirse. De nuevo pasó por las hogueras de campamento donde seguía el juego y el trasiego de vino. De las tiendas salían algunos gemidos, menos que hacía un rato; sin duda el sueño reparador estaba ayudando a los médicos en su tarea. Al Doctor Don Dionisio Daza Chacón, veterano de cien batallas, harto de bregar entre hombres curtidos por la pelea, oidor de dicterios y voces ásperas, le bullía una idea en la cabeza.

- Entre este horror de guerras, dolor y muerte, aún tiene cabida un poeta. ¡Alabado sea Dios!

P.S. El relato anterior es apenas una licencia literaria sobre unos hechos que, si no sucedieron exactamente así, bien pudieron hacerlo. Los personajes -casi todos ellos- son reales; los lugares y los sucesos que los condicionan, también. Marañón en su obra La vida en las galeras en tiempos de Felipe II nos relata algo de la vida de Dionisio Daza Chacón. El encuentro entre éste y Cervantes lo da por sucedido el historiador de la Medicina Anastasio Chinchilla en la Memoria histórico-filosófica sobre las ventajas de la reunión de la Medicina y Cirugía en un solo individuo, especialmente en el ejército (1839). Cervantes, que nos dejó en el prólogo a la segunda parte de $E l$ Quijote la mejor definición de la batalla de Lepanto - «La más alta ocasión que vieron los siglos pasados, presentes y esperan ver los venideros»- $y$ que en varias de sus obras utiliza sus recuerdos de esa época, nada nos dice de quién le atendió de sus heridas; bien pudo ser Daza Chacón. En cualquier caso, estos dos hombres estaban allí en Petala al mismo tiempo y la Historia, tan amiga de estas travesuras, pudo cruzar sus caminos. 


\section{La justicia del arte}

(Primer Premio XIV Concurso «TRIBUNA MÉDICA» de cuentos)

El oficial de los carabinieri, inclinando la cabeza, echó una ojeada por encima de las gafas al sujeto que estaba en pie al otro lado de la mesa. Visto de abajo a arriba era una sucesión de despropósitos vestuarios: unas alpargatas de color indefinible en una de las cuales pugnaba por asomarse el extremo del dedo gordo; unos pantalones que jamás debieron sufrir el peso de la plancha, con bolsillos hinchados por un contenido insondable; camisa floreada, con grandes cercos negruzcos en las sobaqueras y abierta hasta medio pecho en amplio escaparate de una abigarrada colección de cadenas y colgantes sobre fondo peludo. Y coronándolo todo una cabeza como de león desmelenado, con unas greñas revueltas alrededor de un rostro que declaraba en sus rasgos desencajados la intensa y desasosegadora emoción de su propietario.

El oficial se quitó las gafas, las dejó sobre los papeles que cubrían el escritorio y echándose hacia delante extendió los brazos con las palmas abiertas en ademán de pedir calma a su interlocutor.

- A ver, a ver. Tranquilícese y hable despacio para que pueda entenderle. Dice usted que a su amigo...

- Antonio, sí. Lo ha asesinado él -y con todo el cuerpo tembloroso señalaba con un dedo a la espalda del policía.

Éste se volvió y sus ojos se encontraron sólo con la pared de la habitación sin más adorno, entre los chanfarrinones de humedad y polvo, que un calendario en el que se anunciaba un negocio de imprenta bajo una foto algo desvaída de la estatua del David de Miguel Ángel.

- Haga el favor de sentarse y empiece de nuevo toda la historia. -El policía se secó el sudor del cuello con un pañuelo e hizo un gesto a uno de los carabinieri presentes para que acercase un silla.

Sólo hacía veinticuatro horas que el capitán había sido requerido para acudir a la orilla derecha del Arno, un poco aguas abajo del Ponte Vecchio en donde unos turistas madrugadores habían descubierto un cadáver enredado entre las plantas del río. Una vez recuperado el cuerpo comprobó que se trataba de un hombre de mediana edad, vestido con ropas que ahora le recordaban las del visitante de esta mañana. El cadáver mostraba un fuerte golpe en el entrecejo provocado seguramente por un objeto romo, los ojos desorbitadamente abiertos, la boca crispada al igual que los puños, y todo en él permitía reconocer un sentimiento de espanto que debió preceder a la muerte. Seguramente los resultados de la au- 
topsia podrían aclarar algo, pero hasta ese momento la policía y los carabinieri no hubieran sido capaces de establecer ninguna conclusión. Todo pudo ser un accidente; el turista que duerme poco y bebe quizá mucho y acaba una noche por dar un tropezón, o se le vence el cuerpo al asomarse demasiado a los pretiles del puente y en cualquier caso se golpea con una de las piedras del fondo ahora que en verano el río lleva escaso caudal. No era, desde luego, la primera vez ni sería la última.

El muerto se llamaba Antonio con un par de apellidos españoles; era natural de Madrid y tenía cincuenta años. En la documentación encontrada en sus bolsillos no figuraba la profesión, pero por los numerosos papeles con bocetos y apuntes de obras de arte hechos a lápiz que cargaba en una especie de macuto colgado al cuello, se le podía suponer no sólo afición sino un grado alto de dedicación a tareas artísticas. En esos papeles algunos de los dibujos que representaban obras de Miguel Ángel, perfectamente hechos, estaban cruzados por unos trazos que parecían querer emborronarlos aunque sin conseguirlo.

Y ahora, de pronto, con el calor que hacía esa mañana y el rimero de expedientes que había que dejar al menos medio resueltos antes de las ya próximas vacaciones; ahora, se presentaba allí aquel sujeto diciendo no sé qué de un asesinato y señalando a los asesinos en las paredes de la comisaría.

- Antonio y yo somos artistas, escultores, aunque ninguno de los dos vivimos de eso habiendo estudiado Bellas Artes. Antonio trabaja -una sacudida recorrió el cuerpo del hombre-, trabajaba en un ministerio y yo en una compañía de seguros. Pero sentimos la misma afición por la escultura y nos conocimos durante una exposición colectiva que conseguimos celebrar hace unos diez años en Madrid. Nuestra obra es de la que se denomina vanguardista, no figurativa, ya sabe usted a lo que me refiero.

El policía hizo un gesto apenas perceptible arrugando los párpados y la nariz. Eso de vanguardista le hacía imaginar amasijos de hierros retorcidos, objetos inservibles soldados unos con otros, bloques de piedra con un agujero en medio, mil formas absurdas en lo que algunos dicen arte y otros hasta lo elogian y lo ponen sobre los cuernos de la luna. Él por su parte no tenía ningún estudio académico, pero era italiano y además florentino desde hacía veinte generaciones y eso, se quiera o no, marca a una persona con una especial sensibilidad, verdaderamente innata, para apreciar cualquier manifestación artística.

El otro hombre parecía irse tranquilizando a medida que hablaba. Había encendido un cigarrillo y le daba largas y profundas chupadas que 
a veces le provocaban golpes de tos; se restregaba la pernera del pantalón o la pechera de la camisa para enjugar el sudor que le mantenía las manos pringosas. Siguió relatando su historia.

- Allí nos hicimos amigos y desde entonces hemos hecho varias exposiciones juntos. Cada cual tiene su estilo, claro, su personalidad, pero nos compenetramos bien.

- Y ¿vendían ustedes muchas esculturas? -interrumpió el oficial.

- Algunas, sí. No muchas, esa es la verdad; e incluso hubo quien compró una obra y aún no la ha pagado; en realidad de éstos ha habido varios. Pero al menos de una forma u otra, vendiendo, fiando o regalando, hemos dado salida a buena parte de nuestra creación.

"En muchas ocasiones Antonio, yo y otros escultores y pintores de nuestro círculo de amigos hemos charlado y discutido sobre el llamado arte figurativo y el realismo que ahora se han puesto de moda. Ya se puede imaginar que aunque había distintas opiniones la norma general entre nosotros era de rechazo. Antonio, sobre todo, decía que ese tipo de pintura y de escultura están al alcance de cualquiera y que sólo gustan a los nuevos ricos y a gente mediocre. Era tal el entusiasmo que ponía en sus palabras que terminaba por convencer a los que aún mantenían alguna reserva sobre la evidente superioridad de nuestro arte. Solía decir como argumento definitivo que el mejor realismo es la fotografía y que ésta se reduce a un mecanismo de óptica y a un elemental sentido de la oportunidad para hacer esta $u$ otra foto.

El policía estaba empezando a impacientarse. No estaba allí para oír un manifiesto del arte contemporáneo. Se revolvió en el asiento, dio unos golpecitos sobre el tablero de la mesa e interrumpió.

- Bueno, pero vamos al fondo de la cuestión. ¿Qué cree usted que le ha sucedido a su amigo?

- A eso voy. Es que lo que le estoy diciendo es muy importante para que usted comprenda lo que viene después.

- Siga entonces - dijo, con un ademán de resignación.

- El caso es que hace unas semanas surgió una oportunidad para visitar Italia con motivo de un viaje turístico organizado por mi empresa para sus trabajadores y en el que a última hora pudo incluirse Antonio. Al llegar a Roma comenzó la maratón que suelen representar este tipo de viajes. No parábamos de ir de un lado a otro en la pretensión de ver lo más posible durante los dos días de estancia en la ciudad. Allí Antonio todavía estaba normal. Si acaso, al visitar San Pedro y los Museos Vaticanos le noté algo nervioso y le oí murmurar varias veces algo así como "no puede ser, no 
puede ser"; pero lo achaqué al trote al que nos sometían los guías turísticos. Antonio llevaba un cuaderno y en él garabateaba apuntes de muchas obras que íbamos viendo. Siempre dibujó maravillosamente con el lápiz y la plumilla.

"Pero fue al llegar aquí a Florencia cuando se transformó. La visita iba a durar escasamente un día y medio pero me dijo que teníamos que quedarnos. Nunca le había visto tan agitado; tenía un fuego en la mirada que llegó a asustarme. Le recordé que el viaje organizado no admitía demoras y entonces me dijo que renunciaba al resto, que hablaría con la persona responsable del grupo y que él se quedaba en Florencia. Ya ve usted, capitán, le noté tan extraño que decidí quedarme yo también; no podía dejarle solo; no hasta que averiguase lo que le estaba trastornando.

Hizo una pausa para encender otro cigarrillo. El policía, que ahora comenzaba a sentirse interesado por el relato, le instó a continuar.

- Y ¿lo averiguó?

- Aún tardé unos días. Yo le preguntaba, claro, pero sólo respondía con un vago "estoy nervioso, ya se me pasará". Esos días los pasamos casi sin comer; permanecíamos horas y horas en la Capilla Médici viendo los sepulcros que labró Miguel Ángel; en el Museo del Duomo, sentados frente a la Piedad que éste hizo para su propia sepultura, con ese increíble José de Arimatea que es un autorretrato del Buonarroti ia los ochenta años!; y en la Galería de la Academia, sobrecogidos con los Esclavos a medio acabar y, sobre todo, con el David. Antonio copiaba una y otra vez en sus cuadernos todas estas obras con trazos rápidos pero exactos y luego los tachaba con brusquedad.

- Sí, me he dado cuenta de ese detalle, pero no lo acabo de entender.

- Yo tampoco al principio. Si le interrogaba no me decía nada; estaba absorto en su labor de dibujar y dibujar. A veces se quedaba un rato suspenso, mirando fijamente a los ojos de algún personaje esculpido, sobre todo del David que parecía mantenerle la mirada con esa suya de fiereza.

El carabinieri se volvió a mirar de nuevo el calendario que colgaba de la pared a su espalda hacia el que también dirigía su vista el otro hombre. Se sorprendió a sí mismo al descubrir por primera vez que, en efecto, el rostro de David, con toda su increíble belleza, es el de un hombre desafiante, con un punto amenazador en sus ojos y en el gesto de sujetar el extremo de la honda que reposa sobre su hombro. 
- Por fin, anteayer pareció derrumbarse. Estábamos nuevamente frente a la Piedad del autorretrato. Antonio sudaba profusamente; estaba muy pálido y una especie de tic nervioso le sacudía continuamente la boca de la que parecían querer salir palabras. Le dije que saliéramos a la calle a tomar algo porque supuse que eran las muchas horas de ayuno que llevábamos encima lo que le había puesto de esa manera. Entonces se volvió muy despacio hacia mí y me dijo casi tartamudeando: "No es posible, no se puede crear tanta belleza con las manos de un hombre. Esto no puede ser real. Este maldito Miguel Ángel me ha convertido en una piltrafa. Esto no es arte, no es arte, no puede ser arte. Pero entonces, maldita sea, ¿qué es?, y ¿qué soy yo ahora, quieres decírmelo tú? Mi vida entera, todo lo que he defendido se hunde y se aniquila ante estas piedras".

La emoción había hecho de nuevo presa en aquel hombre que se había puesto de pie y se apoyaba ahora con los puños cerrados en la mesa del policía. Éste detuvo con un gesto a los carabinieri que se abalanzaban ya sobre el interrogado temerosos de que se cayera redondo al suelo, tal era el temblor que le sacudía como a un cascabel.

- Antonio se guardó los últimos dibujos y salió corriendo del museo. Yo le seguí cada vez más asustado. Llegamos casi a la carrera hasta la iglesia de Santa Croce. Antonio primero y yo en persecución suya cruzamos la nave del templo y mi amigo se detuvo como si hubiera chocado con algo frente a la tumba de Miguel Ángel. Si antes estaba pálido ahora estaba encendido como si le ardieran las entrañas y todo su fuego interior pugnara por salir a través de los ojos. Alzó los puños crispados y gritó: “iMiguel Ángel, maldito seas mil veces; yo te maldigo y te desafío! iSal de ahí y demuéstrame que un hombre, sólo un hombre, puede crear lo que tú has hecho! ¡Maldito, maldito!". Y cayó de rodillas sollozando primero para luego romper a llorar como un chiquillo en pleno desamparo. Al agacharme para sujetarlo se abrazó a mí sin dejar de mirar al mausoleo y le oí decir entre gemidos: "¡Dame tu arte, maldito; dámelo o te juro que te destruiré!".

El policía, que notaba cómo todo su cuerpo se iba poniendo tenso al compás de aquel relato tan vívidamente expuesto, creyó llegado el momento de serenar los ánimos y para ello adoptó un aire profesional.

- Una actitud rara, en efecto; en cualquier caso, exagerada. Pero creo que todo esto que me cuenta de su amigo puede encajarse dentro de lo que los médicos llaman «síndrome de Stendhal». Se trata de una reacción curiosa que se produce en algunos visi- 
tantes de ciudades como esta Florencia u otras tan cargadas como ella de arte. Los médicos dicen que se debe a una saturación en poco tiempo de la capacidad humana para recibir impresiones de belleza; según ellos, se manifiesta en forma de mareos, depresión o excitación y trastornos del comportamiento. Es, desde luego, benigna, se pasa en pocas horas o días nada más que con reposo. Parece ser que la describió el propio Stendhal en sí mismo cuando en el siglo pasado visitó las ciudades italianas y que la sintió precisamente aquí en Florencia.

- Pero Antonio no es un turista cualquiera. A lo largo de su vida ha visto infinidad de obras de arte. No iba a saturársele la cabeza por cuatro días en Florencia ni en ningún otro lado. Y además Antonio podía estar nervioso, pero no ha muerto por eso. Lo ha matado él -y volvió a señalar con el dedo la fotografía del David.

- Ya empezamos otra vez. Dígame claramente qué tontería es esta del calendario. $\mathrm{O}$, si lo prefiere, venga mañana cuando se haya serenado un poco y sacaré un rato para charlar con usted.

- No, señor. Le digo que a Antonio lo ha matado David. Yo lo vi; bueno, lo entreví, o creo haberlo visto, ya no estoy seguro de casi nada. Pero tengo que contárselo ahora mismo. La otra noche, cuando Antonio ya parecía más calmado después de la escena de Santa Croce, fuimos a pasear por el Ponte Vecchio y por la orilla del río. Le hice comer un buen plato de pasta y otro de carne porque todavía seguía creyendo que el motivo de todo era el hambre. Pues bien, en un momento mi amigo se adelantó unos metros y de pronto le oí gritar: "iNo, por favor, no!, jno lo haré, he mentido, estaba obcecado, perdón, perdón!". Y entonces vi una silueta mal definida reflejada en el agua. Era la de un hombre grande, eso sí lo sé. Movía un brazo y a su extremo giraba a gran velocidad un objeto alargado. Luego oí un zumbido que cruzaba el aire muy cerca de mí y un golpe seco que ahogó el último grito de Antonio. Se lo juro, capitán, me entró pánico y en vez de correr hacia donde debía de estar mi amigo lo hice en dirección contraria. He estado deambulando por las calles desde entonces; he maldormido sobre la escalinata de Santa María del Fiore rodeado de una docena de hippies que pasaban la noche allí. $Y$ he venido a verle en cuanto se me ha pasado un poco el miedo. Eso es todo.

- Está bien -el policía se puso en pie y cruzó al otro lado del escritorio para echarle un brazo por los hombros a aquel sujeto 
que ahora parecía un globo desinflado-. Ahora debe usted ir a un albergue que le proporcionaremos. No se mueva de allí en un par de días por si le necesito. Cualquier cosa que sepamos se la comunicaré de inmediato. Muchas gracias por su ayuda; ha sido muy valiosa, de verdad.

Unas horas después el capitán estaba en una cafetería próxima al cuartelillo tomando un capuchino con su amigo el médico forense. Hablaban del español muerto en el río.

- Ya te daré los resultados completos -decía el médico-, pero puedo adelantarte que llevaba en su cuerpo una buena cantidad de alcohol, probablemente chianti o algo parecido; se conoce que regó con generosidad los spaghettis y la carne que cenó. Debió caerse desde lo alto del puente como tú suponías, porque tenía en la frente una gran herida sin duda provocada por una piedra de regular tamaño del fondo del río; vamos, como una pedrada entre los dos ojos; ¡mala suerte!

$\mathrm{Al}$ otro lado del mostrador, fijado con cuatro chinchetas, estaba un gran cartel de la oficina turística de Florencia. Una vez más se reproducía en él la figura, esta vez completa, del David miguelangelesco. El capitán, mientras esbozaba una sonrisa al mirar aquella imagen de la que tanto había oído hablar esa mañana, dijo a su compañero de café.

- Oye, si un tipo tan grande como ése anduviera por las calles, aunque fuese de noche, alguien lo tendría que ver ¿no?

El médico forense, entretenido en ojear las enormes páginas del periódico, no oyó la pregunta.

\section{El amor de una lumbre}

(Primer Premio I Concurso Literario para Médicos, Fundación Sanitas)

Cuando el mendigo harapiento y sucio arrancó del suelo aquellas tablas que formaban una tosca cruz, ignoraba de quién era la tumba que estaba profanando. De saberlo, tampoco se hubiera detenido en su macabro expolio. Hacía un frío que helaba la sangre y, desde luego, el raciocinio y la conciencia; un frío que hacía difícil mover las manos endurecidas por la humedad congelada; la única energía disponible era la desesperación y de ésa el mendigo tenía aún suficiente acopio. Metió las maderas en un mugriento saco de tela que llevaba colgado por una cuerda de la cintura, se echó el aliento sobre las puntas de los dedos y anduvo unos pasos escarbando con 
los pies entre los matojos blancos de escarcha a la busca de algo combustible que añadir a su menguado botín de esa mañana.

Aquella huesa profanada hacía mucho tiempo que no era visitada por nadie. Hasta unos años antes solía recibir sobre la tierra el leve peso de unas flores recién cortadas y también unas lágrimas de mujer. Pero ya pasó todo. Con la mujer y su humilde ofrenda se perdió hasta la memoria del que yacía en lo que fue calvero de un bosque y después páramo inhóspito abierto al resoplar del viento helador y al monótono, incansable caer de la nieve. Unos pocos meses, durante la estación cálida, un tímido verdor cubría la paramera como negándose a aceptar la muerte de la tierra; y hasta algún pájaro perdido en sus caminos de aire llegaba a posarse sobre los brazos de la cruz para reemprender enseguida el vuelo, sin ni siquiera entretenerse en emitir un gorjeo que rompiera el abrumador silencio que pesaba como una roca colosal puesta por el Creador en aquel lugar olvidado de los hombres.

Juan hizo de la ecología su vida y la ecología marcó su muerte. Desde muy niño se integró en uno de los grupos defensores a ultranza de lo natural y con la juventud radicalizó al extremo su postura. Fue cabecilla indiscutible de sus primeros compañeros y más tarde líder mundial del movimiento ecologista. Su nombre era el más respetado por todos los medios de comunicación y con él se bautizaron miles de niños en todo el mundo, como fervoroso homenaje a quien venía a representar el nacimiento de una nueva humanidad, más sana, más limpia, más respetuosa con el ambiente natural, más libre de la opresión sufrida hasta entonces por culpa de una industrialización sin freno. Juan Ecólogo fue, más que un hombre, el símbolo vivo del naturalismo triunfante.

Cuando Juan comenzó su actividad el mundo había cambiado ya mucho en comparación con el que les tocó vivir a sus padres y más aún a sus abuelos. La lucha ecologista no era nueva y llevaba mucho camino avanzado. Numerosas fábricas en todos los países acomodaron sus procesos industriales a normas tendentes a proteger de vertidos y humos a la naturaleza. Millones de hectáreas permanecían en secano porque se detuvo la construcción de embalses que hubieran anegado amplias zonas de monte. Ciertamente con esta misma falta de embalses se había resentido la producción de energía eléctrica, ya de por sí aminorada por la estricta prohibición de las centrales nucleares y las térmicas, tan contaminantes y peligrosas unas como otras. Pero, a menos electricidad, más energía natural con fuegos de carbón y leña; claro que pronto hubo que suprimir la leña porque los pueblos se deforestaban con las talas incontroladas.

La sociedad condenó primero al desprecio y luego a la cárcel a quienes utilizasen pieles de animales en su vestuario; un abrigo de astracán, 
y no digamos uno de zorros o de visón 'eran motivo de proscripción pública; la lana y el algodón se convirtieron en las únicas fibras textiles toleradas toda vez que las sintéticas provenían de un proceso de fabricación tenido por vituperable y la seda obligaba a matar a millones de indefensas mariposas.

Asimismo se habían proscrito, después de muy arduos debates entre los miembros de los distintos gobiernos, los abonos artificiales para la agricultura; aquí la rama macrobiótica del movimiento ecologista llevó la voz cantante y obtuvo uno de sus mayores éxitos; sólo abonos naturales, buen estiércol y un poco de nitrato de Chile que al fin y al cabo es el excremento de unos pájaros; estos abonos tenían el inconveniente, siempre subsanable con buena voluntad, de su alto precio y de que hubiera que ir a buscarlos en explotaciones ganaderas algunas de las cuales llegaron a especular miserablemente con los restos digestivos de sus vacas y ovejas.

Juan no se sentía satisfecho con lo conseguido hasta su época. Él quería llevar la realización de sus convicciones hasta el extremo, y que cayera quien hubiese de caer. La más innovadora de sus ideas fue la creación de un ejército ecologista cuya misión sería la de imponer por la fuerza los principios ecológicos ya que, a su juicio, la extensión de los mismos al mundo entero mediante la propaganda o el debate en los foros políticos y económicos, era demasiado lenta y dejaba tras de sí numerosas lagunas que los hacían ineficaces. Juan recordaba la historia de la Revolución Francesa y cómo aquellos principios de la Razón y del Liberalismo se habían extendido fecundamente por Europa no con misiones diplomáticas o con el ejemplo de sus promotores, sino aupados sobre las bayonetas de Napoleón. En este asunto de salvar a la naturaleza el tiempo es un factor decisivo que siempre corre en su contra. Era necesario, pues, acortar plazos, saltarse convencionalismos, derrumbar murallas de incomprensión o cerrazones mentales. Y así se fundó el Ejército Verde que muy pronto recibió el apoyo incondicional de los partidos políticos ecologistas que poco a poco habían alcanzado las mayorías parlamentarias en varias naciones europeas. Un ejército cuyo primer general en jefe fue el mismo Juan, poco amigo de delegar en otros las responsabilidades y los riesgos que su misión trascendental exigía.

El primer objetivo fueron unas fábricas de productos químicos para el teñido de telas que, con carácter poco menos que artesanal, se mantenían clandestinamente en varios pueblos de la serranía. El Ejército Verde contaba, a buen precio, con una amplísima red de confidentes que hizo saber a su Estado Mayor la existencia de aquellas industrias. Al poco de salir el sol, una mañana de primavera, los edificios fueron incendiados y sus restos derribados piedra a piedra. Los dueños y sus pocos trabajadores, 
casi todos de la familia, conducidos en una vieja tartana de caballos hasta la ciudad y allí sometidos a juicio sumarísimo y encarcelados.

Se multiplicaron las acciones de combate y castigo. Las hubieron de sufrir en sus bienes y en las costillas de sus gentes centenares de pequeñas empresas tenidas por vitandas y que hasta entonces habían podido soslayar, mal que bien, las sucesivas legislaciones.

Otro día se desató una campaña contra los insecticidas. Primero fueron los utilizados en los campos de labor y en los plantíos de frutales. No sólo eran perjudiciales para la salud, como enseguida manifestaron los macrobióticos, sino que además alteraban muy seriamente el ecosistema: morían aves y otros animales envenenados y se mataba a miríadas de insectos que tenían el mismo derecho que cualquier otro ser vivo, incluido el hombre, por supuesto, a la existencia. Luego les tocó el turno a los hogareños que pecaban del mismo defecto de destruir la vida de moscas, mosquitos, polillas y cucarachas, deseables copartícipes con nosotros de un mundo sano y limpio.

Juan y sus colaboradores más íntimos en la planificación de ese mundo buscaban, al igual que los grandes estrategas de la Historia, una acción con suficiente espectacularidad como para asombrar al pueblo que representaban y, a la vez, capaz de sobrecoger de espanto al enemigo y a cuantos siquiera pensasen por un instante en enfrentarse a ellos y a su verdad absoluta. Se hacía preciso una Cruzada de gran magnitud y de inusitada dureza; algo como jamás vieron los tiempos. El objetivo a batir se les apareció enseguida con meridiana claridad: el tabaco y los malhadados fumadores.

Hombres y mujeres que tenían el vicio nefando de fumar fueron perseguidos, acosados, cazados como animales dañinos ahora que se había declarado a todos los demás animales como poseedores del derecho inalienable a la vida libre. Esos miserables fumadores lesionaban con sus humos el bienestar y la salud del resto de los ciudadanos, contaminaban con los detritus de su vicio el medio ambiente, y eso no se podía tolerar. Bien estaba que se liberalizase el uso de las drogas psicotropas, porque tales sustancias, como había manifestado de forma reiterada y convincente muchos miembros de los partidos ecologistas, no sólo no perjudicaban al prójimo sino que eran altamente beneficiosas para el bienestar individual de sus usuarios que no tenían por qué ser marginados de la sociedad; pero de eso a permitir el consumo de tabaco había un abismo.

La ejemplaridad de la Cruzada antitabaco requería un castigo de tal naturaleza que el encarcelamiento y las sanciones pecuniarias con que por lo común se solventaban otros delitos ecológicos eran un regalo. De este modo se decidió que todo fumador cogido in fraganti o en posesión de 


\section{José Ignacio de Arana Amurrio}

la más pequeña cantidad de tabaco, sería empalado en la orilla de los caminos y carreteras. A pesar de que campañas anteriores de concienciación ciudadana habían conseguido disminuir drásticamente el número de personas ligadas a tan horrible vicio, aún quedaban muchos recalcitrantes y no pocos contumaces, de esos que habiendo dejado por un tiempo la mala costumbre de fumar cayeron de nuevo en la sima de la perdición. En la cacería participaron con notable éxito, siendo muy felicitados públicamente por ello, antiguos fumadores y fumadoras, especialmente hábiles por el resabio de su pasada lacra en detectar el olor del tabaco en el aliento y en los dedos de los acusados, por más que éstos hubieran intentado camuflarlo con enjabonamientos y perfumes.

La red viaria se jalonó de estacas con sus reos espetados para público escarmiento; cada cincuenta metros, un ramillete; cada miliario, un centenar. Los sembradíos de tabaco fueron arrasados y su terreno se cubrió de sal. Se utilizaron voluntarios para expurgar las librerías y las hemerotecas tachando o arrancando cualquier dibujo o fotografía en la que apareciese una persona fumando o una marginal referencia al tabaco; esto se llevó a cabo tan a conciencia que de algunas figuras históricas como Winston Churchill hubieron de improvisarse retratos imaginarios para los libros de texto porque todos los reales quedaron destruidos al estar siempre el sujeto unido íntimamente a un cigarro puro.

Ya puestos a ello, la imaginación de los hombres no tiene límite. Fueron abolidas las Fallas de Valencia y las Hogueras de San Juan por la contaminación aérea de sus humos y ambiental de sus ruidos de cohetes y triquitraques. La mal llamada fiesta de los toros fue, como es natural, suprimida bajo pena de muerte en el desolladero para los transgresores, fueran éstos toreros o simples espectadores de tan brutal como inadmisible orgía de sangre y sufrimiento de unos pobres animales.

Las cosas fueron un poco más complicadas cuando se quiso llevar a efecto otra de las ideas luminosas de aquellos adalides del naturismo. Se trataba de impedir la tala de millones de árboles utilizados en la fabricación de papel, sobre todo de papel prensa, pero también para otros usos. Algunos parlamentarios, anclados sin duda en la obsoleta mentalidad que por fortuna iba siendo derrotada por los nuevos tiempos, objetaron que con esa medida se iba en detrimento de toda la cultura escrita. Con gran espíritu de condescendencia se accedió a debatir sus objeciones, pero claro, para eso están las mayorías, faltaría más, fueron derrotados en la votación y se les amonestó severamente para que en adelante no mareasen más.

Los medios de comunicación, de información y educativos quedaron, pues, limitados a la televisión y, en mucha menor medida, a la radio. 
Apenas tres o cuatro publicaciones utilizaban papel reciclado que terminó por agotarse al cabo de poco tiempo. La televisión, durante las cinco horas diarias de programación que permitían las restricciones eléctricas vigentes, se ocupaba de manera fundamental en concursos donde el premio mayor era un coche movido por energía solar, monoplaza, de líneas atrevidas ya que no estéticas, capaz de circular a treinta kilómetros por hora con una autonomía, en días soleados, de más de tres horas: una maravilla de los nuevos tiempos, no demasiado útil, esa es la verdad, pero una maravilla.

Llegó el día en que el Ejército Verde había alcanzado sus últimos objetivos. De grado -la mayoría - o por fuerza, todos ahorraban agua; comían unas hortalizas entecas y picoteadas por el gorgojo, pero muy sabrosas y nutritivas; cocinaban con leña recogida en el suelo de los bosques; curaban sus enfermedades, o las aliviaban cuando menos, con emplastos y tisanas; vestían gruesas prendas de lana al exterior y de algodón en contacto con las carnes; o se divertían con apasionantes concursos televisivos en los que una pareja de novios competía con otra en responder acertadamente, entre mohines de ellas y gestos pícaros de sus compañeros, a las preguntas que se les planteaba sobre cómo organizar su futuro hogar de acuerdo con los principios de la ecología. Desde luego, no existía el paro laboral ya que todos los brazos eran necesarios como fuente energética para cualquier labor cotidiana, desde lavar las sábanas a moler el trigo o arrastrar por las calles un carretón de leña para la cocina o de humeante estiércol para la huertecilla familiar.

Pero ni el mayor y mejor pertrechado ejército ha sido nunca capaz de someter hasta la anulación las más íntimas pasiones y necesidades de los hombres. Así sucedió también con el Ejército Verde. No es que se creara un movimiento de resistencia entre la población al igual que otros que recoge la Historia; la cosa sucedió más espontáneamente, sin nadie que la dirigiera o se colocase a su cabeza; aquí o allá brotó como esos jaramagos que de pronto, sin que nadie se lo explique ni lo espere, nacen en medio del asfalto o entre las invisibles rendijas de un roquedal; alguien o algo, animal o viento, puso allí la semilla, o quizá estaba de siempre y los fríos y los hielos y las máquinas no la supieron conocer para destruirla.

En muchos puntos a la vez alguien pensó que aquella vida tan sana, tan pura, tan en íntimo contacto con la naturaleza, era una vida de hambre y de frío; que seguramente no valía la pena estar tan sano con la gazuza rugiendo en el propio estómago y en el de los hijos, y el frío traspasando los huesos mineralizados y vitaminados; y también pensó que el hombre es el amo de la naturaleza y no una pieza más de la misma, aun- 


\section{José Ignacio de Arana Amurrio}

que tenga que cuidar su dominio como lo hace cualquier buen amo con sus bienes.

El miedo atenazaba los ánimos que así pensaban, y las vigilantes patrullas del Ejército Verde se encargaban de que ese miedo estuviera siempre presente. Mas, con todo y eso, el movimiento fue tomando envergadura. Al principio no pasó de ser una corriente de opinión que apenas traspasaba el recato de las conversaciones con los más íntimos y podía traslucirse en que sus adeptos se negaban a permanecer ni siquiera un rato frente al televisor desde donde se impartían las consignas del poder vigente. Luego fueron pasando a la acción.

Hasta las necesidades y apremios más elementales tienen una jerarquía, de modo que lo primero fue lograr una dieta más sabrosa y que saciase más las ganas de comer. Unos huevos fritos con chorizo o con torreznos, antaño plato de dioses, pero ahora vituperable amasijo de colesterol por el que entran en el cuerpo más de una docena de enfermedades conocidas, llegó a convertirse en el centro de algunos conciliábulos secretísimos, reuniones de catacumba con olor a fritanga. En público había que seguir comiendo y bebiendo alimentos sin grasas, bajos en calorías, con el azúcar reducido a la mínima expresión, por supuesto que sin alcohol y, por mucho que se empeñaran sus promotores, también sin sabor y sin gracia. Pero cabía el consuelo de ser invitado alguna vez a una de esas otras comidas en las que se sacaba el cuerpo de penas para una larga temporada.

Renació un olvidado estraperlo de tabaco y de café, complementos casi imprescindibles de las otras transgresiones a las normas. Nadie sabía la procedencia de aquellos artículos tan severamente perseguidos y de consumo tan castigado. Se oían rumores, que más parecían leyendas para encarecer el precio, sobre plantaciones clandestinas en algunos países atrasados de Hispanoamérica y el sudeste asiático; de caravanas que se jugaban la vida para traerlos desde tan lejanos lugares; y de mafias que se enriquecían a costa de los vicios y la debilidad humanos. En algunas ocasiones las patrullas verdes llegaron a decomisar algún cargamento oculto entre la marihuana y la cocaína destinadas a los estancos y a los colegios.

Si con unas cosas y otras se conseguía que a veces el cuerpo entrase en calor por dentro, había que buscar también con qué calentarlo por fuera. De modo que se volvió a la tala de árboles y a las leñeras camufladas en algún rincón oscuro de la casa. Las familias reencontraron el placer de reunirse alrededor de un fuego en animada conversación o con cada cual ensimismado en sus pensamientos o en sus sueños.

Viejos sótanos se convirtieron en talleres y fábricas artesanales al amparo del secreto cómplice de unos pocos iniciados. Allí se elaboraban, 
según fórmulas rescatadas del olvido y la prohibición, jabones de olor; pilas eléctricas con cobre viejo y ácido buscado en algún recóndito almacén; extrañas mezclas combustibles que permitieran a un vehículo ir tirando un poco más aunque fuese a trompicones; piensos para los animales con desechos de basurero y alcantarilla; y cualquier cosa que pudiera hacer más llevadera, más humana la existencia aun a costa de perturbar en algo el equilibrio natural.

Los científicos preecologistas habían predicho para el futuro algo que llamaron "efecto invernadero». La Tierra, cubierta por una espesa capa de humos industriales, con su atmósfera recalentada por tanta energía dilapidada y sin capa de ozono protectora, habría de perecer bajo las aguas de los hielos polares derretidos; un nuevo diluvio, pero esta vez no caído del cielo sino surgido de los mares; y quizá, aunque esto nadie lo decía, un nuevo Noé salvando in extremis la humanidad y la vida animal a bordo de un arca. No fue así. Lo que cubrió la Tierra fue el frío. Un frío que primero heló el suelo para luego introducirse en los cuerpos y finalmente en los corazones, en las almas de los hombres. Alguien avisó tímidamente recordando que lo más característico, quizá, de los tiempos preindustriales, de aquellos milenios en que la humanidad anduvo por necesidad más apegada a la naturaleza, fue precisamente el frío que lo mismo atenazaba a los moradores de los palacios que torturaba a los que lo sufrían en las chozas o en las casonas destempladas. Pero no se le hizo caso; es más, su advertencia fue tomada por la exageración de alguien que no sabía adaptarse a los nuevos tiempos y, por lo tanto, condenada al desprecio y al anatema.

Los bosques fueron cayendo uno tras otro; furtivamente al principio, salvajemente después. La búsqueda de calor se convirtió en la primera necesidad para gran parte de los hombres; en muchos casos anterior incluso a la de comer. Aquellos antecesores nuestros que habitaban en las cavernas -más ecologistas que nadie, ja ver qué remedio!-- debieron sentir otro tanto mientras pintaban caballos y bisontes en las rocosas paredes de sus viviendas y se aplicaban con entusiasmo al siempre enardecedor ejercicio de la caza y al no menos cálido de la fornicación.

Juan Ecólogo tardó en darse cuenta de la situación, del rumbo que tomaban los acontecimientos. En un principio, apoyado aún por la mayoría de sus seguidores de primera hora, trató de combatirla intensificando la propaganda de los ideales ecológicos, de los maravillosos resultados esperables a corto plazo con la vigencia y puesta en práctica de esos ideales; utilizó exhaustivamente su Ejército Verde, pero tuvo que contemplar con ira, con resignación, con profundo desencanto, según pasaba el tiempo, las deserciones de los suyos. Ella, la compañera desde 


\section{José Ignacio de Arana Amurrio}

siempre, seguía a su lado; era su continuo acicate y llegó a ser su único consuelo.

El mundo quería cambiar, pero le iba a ser difícil si no imposible. Ya era demasiado tarde. Si el desenfrenado uso de la naturaleza amenazaba seriamente con destruirla hasta el advenimiento de la era ecológica, la llegada de ésta vino a segar de raíz las posibilidades de un desarrollo humano. Se había pasado de un extremo al otro en un sobrecogedor bandazo al modo de estar el hombre en el mundo. Se había perdido la oportunidad de modificar muchas conductas, sin suprimirlas por completo, para alcanzar una armoniosas relación entre las necesidades humanas y su progreso por una parte y la conservación por otra de un bien tan perecedero como la naturaleza. Una vez más todo exceso se demostraba inconveniente y preñado del riesgo de no permitir la vuelta atrás; el arrepentimiento en estos asuntos no puede ser constante; llega un día en que hay que apechugar para siempre con las consecuencias.

Juan se fue quedando solo; solo con ella que le seguiría a cualquier parte. Y decidió irse al calvero de un bosque donde tiempo atrás se hizo una choza con cortezas de robles y techumbre de junquera. Allí serían felices; allí la naturaleza y ellos serían una misma cosa; allí tendrían la visita de los fieles y desde allí conseguirían otra vez proclamar y expandir su evangelio ecologista.

Aquel invierno se debió de helar hasta el sol porque cada mañana parecía más remiso a asomarse por la línea ondulada de los montes y luego sus rayos se quedaban yertos antes de alcanzar la piel del hombre y la mujer que salían a buscarlos a la puerta de su cabaña. Los siempre cantarines pájaros de la arboleda y los zumbadores insectos habían enmudecido; los únicos ruidos que acompañaban la decaída conversación de los dos seres humanos eran el viento entre la enramada y el crepitar mortecino de un puñado de tamuja y otro de cascabillo que ardían en el improvisado hogar de la casucha regalando más humo que calorías. Uno al otro se daban calor en la yacija y el cariño tomó la forma casi única de un contacto tibio que consolaba cada noche los helores de cada día.

Un hombre hecho desde la niñez a la acción soporta mal la inactividad. Juan no se resignaba a la quietud de su nueva vida, ni siquiera a cambio de gozar por primera vez en tantos años de tiempo para amar y sentirse amado en singular; porque hasta entonces gozó del amor de las multitudes y él entregó el suyo a la humanidad entera, pero sólo ahora empezaba a intuir que existían dos clases muy diferentes de amor y que la filantropía tiene muy poco que ver con ese extraño flujo que brota del encuentro entre un hombre y una mujer. Aun así un amargo rescoldo le desazonaba en lo más profundo de su ser. 
Una mañana, con los primeros albores del día, llegaron hasta el improvisado hogar de la pareja cinco o seis hombres. Juan los reconoció a distancia como algunos de sus más fieles oficiales en el Ejército Verde y les salió al encuentro con los brazos abiertos adelantando el abrazo en que terminaron por fundirse todos ellos. Se les veía animosos, o mejor sería decir enardecidos; gesticulaban y hacían mil ademanes por los que se podía adivinar que eran portadores de noticias importantes y urgentes.

La cosa no era, en realidad, para menos. Las fuerzas ecologistas se estaban reagrupando dispuestas a tomar la iniciativa. Pero necesitaban a su jefe natural, a Juan Ecólogo. Sin él nada se podría conseguir pues su sola presencia enardecería de tal modo a sus seguidores que superarían, siendo ahora menos, a cualquier enemigo. A Juan se le iluminó en el cerebro el recuerdo de Elba; Napoleón regresando de su destierro para hacerse de nuevo señor de Europa; sus enemigos huyendo ante el solo rumor de su retorno o corriendo a ponerse bajo sus banderas otra vez triunfantes. Claro que al final estaba Waterloo, pero los recuerdos tienen la ventaja sobre la realidad de que se pueden modificar al antojo de quien los revive, y se pueden cortar aquí o allá como quien lee un libro y lo cierra por la página que no le gusta o se la salta.

Juan y su Estado Mayor contemplaron a los pocos días el grueso de sus fuerzas. Eran bastante menos numerosas de lo que habían supuesto: un disculpable error de optimismo o de prever cómo serán los hechos por cómo nos gustaría que fuesen. Era igual. Y el ánimo y el esfuerzo y la seguridad en sí mismo ¿no valen nada?; claro que sí. Lo iban a demostrar bien pronto en su primera acción. Luego se les unirían muchos más: todos los que ahora estaban indecisos; y también los que siempre esperan a ver de qué lado se inclina una balanza para subirse al platillo ganador, que es otra forma distinta de indecisión con la que deben contar los ganadores de cualquier batalla.

En un pueblo pirenaico sus habitantes habían organizado un próspero negocio alrededor de los ganados que pastaban en su alfoz durante los meses cálidos. Un matadero, un taller de curtidos y una tenería completaban la utilización de los animales, con gran aceptación de sus productos alimenticios y vestuarios aun a costa de transgredir una docena de normas ecológicas. También la primera vez que el Ejército Verde, recién fundado por Juan, actuó por el bien común lo hizo contra una industria parecida; sin duda se trataba de un buen augurio.

El pueblo se encontraba a mitad de altura entre el valle y la cima de una de las montañas que forman la cordillera. Era invierno y la nieve cubría casi por completo el paisaje hasta donde alcanzaba la vista. Ape- 
nas algún tejado de pizarra dejaba entrever un poco su color entre la uniforme blancura señalando la posición de las casas. Las ramas cimeras de los árboles, de un verde casi negro, mojonaban las laderas durante un trecho para luego perderse. El camino que condujera allí arriba desde la llanada se había perdido y la subida no se presentaba fácil para los atacantes. Juan miró tras de sí y vio cómo algunos de sus hombres se volvían atrás iniciando el regreso a sus hogares; lo hacían sin aparente prisa ni tampoco ocultándose; no como quien huye sino como quien da por fracasado de antemano el logro de un objetivo y prefiere no perder más el tiempo en seguir adelante. Juan quiso gritar, insultarlos, amenazarlos, pero la voz no salió de su garganta.

En los primeros pasos, con la nieve hasta las rodillas, Juan sintió frío y creyó percibir en la nariz el consolador aroma de aquel fuego que él y ella mantenían encendido en su choza. Fue sólo un instante; se sobrepuso de inmediato y le quedó en el ánimo una punzada de vergüenza, como de haber faltado a su destino por aquella brevísima concesión a la añoranza. Continuó ascendiendo; al principio oía a su espalda las voces de los que le seguían; eran voces de estímulo y alguna de reniego; después dejó de oírlas y únicamente el crepitar de la nieve bajo sus botas rompía el silencio. Si hubiese vuelto la cabeza entonces se habría encontrado solo, pero no lo hizo.

Un alud no se anuncia; se desencadena de improviso y sólo durante una fracción de segundo es posible recibir la intuición más que el sonido de la montaña que cruje y se despereza. Luego ya no hay escapatoria y el derrumbe se lleva consigo todo cuanto encuentra en su camino hacia la hondura. Y allí, en ese camino insoslayable, estaba Juan y la naturaleza lo arrastró sin que se diera cuenta de que estaba solo. Al ver la nieve en avalancha se agarró a lo primero que tuvo a mano; era un plantón reciente de árbol y la fuerza de la caída hizo que se desarraigara como una brizna de hierba y acompañase en su último viaje a Juan, sujeto en su puño crispado.

Unos pocos de los hombres que habían ido a buscar a su jefe a la choza del calvero fueron testigos lejanos y seguros de la desgracia. Rescataron el cuerpo cavando en la nieve con sus manos y las culatas de las armas. Al ver que aún tenía entre los dedos el delgado tronco del arbolillo, uno se permitió comentar: "Parece mentira que Juan haya sido capaz de destruir un árbol, iquién lo hubiera dicho!». Los otros miraron con desprecio al que hablaba, envolvieron a su jefe y amigo entre dos mantas e iniciaron la vuelta hacia el mismo lugar donde apenas unos días antes se encontraron todos con los ánimos exaltados por la ilusión del triunfo. Napoleón sobrevivió a Waterloo, pero quizá ésa fue su mayor desgracia por- 
que le obligó a sufrir dos veces la derrota. Juan, en esto, fue más afortunado que su ídolo histórico.

Ella lo enterró en el mismo calvero con ayuda de aquellos hombres. Puso sobre el hoyo una cruz de palo y se quedó llorando a su lado. En los días siguientes vinieron gentes de muchos lugares a darle consuelo queriendo llevársela a la ciudad donde, decían, la vida sigue. No quiso ir con nadie porque todo lo suyo estaba en aquel trozo de tierra removida sobre la que plantó unas flores que también se helaron y en la que más tarde depositaba día a día un ramillete de jaramagos o de amapolas o de clavellinas y de violetas.

Pasó el tiempo y el calvero, apenas un minúsculo claro en la espesura de aquel bosque según lo hubieran visto la golondrina o el milano que a veces surcaban el trozo de cielo que lo cubría, oyó los golpes secos, rítmicos, de las hachas que talaban cada vez más cerca los árboles y luego vio los rostros fieros, curtidos, de los leñadores que hacían su labor como movidos por un espíritu demoníaco que los impulsara a la destrucción. Llegó a faltar el bosque y la choza y la tumba se encontraron solas en mitad del páramo, como único testimonio, a la vez, de vida y muerte en muchos kilómetros a la redonda.

Ella terminó cediendo y buscó cobijo en casa de unos familiares de una ciudad en la que las gentes se agrupaban porque ya no sabían vivir de otro modo. Aquello del contacto con la naturaleza libre y pura estaba muy bien para un desahogo de fin de semana o de vacación, pero cuando esa naturaleza libre se demostró también salvaje y enseñó los dientes, la ciudad apareció como un refugio; se estaban descubriendo, como en una revuelta de la espiral de los tiempos, las ventajas de la civilización.

Aun así no dejó de acudir casi a diario hasta la paramera. La mujer se quedaba un largo rato junto a la tumba, pero luego corría a refugiarse al amor de una lumbre que terminaba venciendo al otro amor, el del héroe muerto.

\section{La mirada de la reina}

(Accésit XI Premio «TRIBUNA MÉDICA» de Cuentos)

- ¿Qué pesada es María Agustina! Pero si yo ahora no quiero beber agua; y ella empeñada en darme el búcaro; isi al menos fuese de chocolate!; pero ¡qué va!, eso sólo lo toman los mayores, con las ganas que yo tengo de tomarme una jícara de las que se almuerzan ellos, con ese olorcillo tan gustoso. ¿Que no, María Agustina, déjame ahora tranquila! ¡Qué guapa está mi madre con esas ropas nue- 
vas y el aderezo que le regaló el Condestable! Pues, ¿y mi padre? Siempre oigo decir que el rey es muy serio, y doña Isabel Velasco le llamó triste la otra tarde. Yo creo que es el hombre más simpático y cariñoso del mundo, y el más guapo y el más... ¡Cuánto les quiero a los dos! Me gustaría estar más veces con ellos y darles besos, y subirme al regazo de mamá o a los hombros de papá sin que vengan corriendo mis meninas o doña Marcela para regañarme. A ellos también les gusta, sobre todo a papá; y me hace cosquillas con el bigote y simula el trotar de un caballo con sus rodillas y el ruido de los cascos chasqueando la lengua... ¡Que no, María Agustina, que no quiero agua!

- Menguado oficio es este mío. Pero, en fin, ¡cómo ha de ser! Mientras haya damas en el mundo -que no se han de acabar-tendrán necesidad los palacios de servidores como yo. Por más que tampoco me agobia la faena, siendo como es lo peor de ella el aguantar a esta doña Marcela de Ulloa, que no parece sino que si se calla se muere. El mayordomo quiso sin duda compensar a un guardadamas taciturno con una dueña de lengua imparable. Me pone dolor de cabeza tanto oír minucias de la casa, tanto murmurar de unos y de otros; que si la infanta juega más de lo que se debe a su condición y con impropia desenvoltura; que si habrá que hablar a sus majestades de la conveniencia de cambiar las meninas porque éstas empiezan a pensar más en sus asuntos que en el solaz y acompañamiento de doña Margarita; que si éste dice y aquél deja de decir... Si el mayordomo atendiera a mis ruegos y, de acuerdo a mis méritos, me nombrase camarero... Pero me parece que antes atenderá a Miguel de Molina que le trajo una esquela de su tío el canónigo. Y el caso es que llevo yo en este oficio de celar el gallinero más de veinte años y sería tiempo de mudarlo. En la cámara del rey siempre se hisopan prebendas y malo sería que no me cayese alguna sin buscarla. ¿Callará esta mujer? No me he de olvidar, así se recoja la infanta, de buscar al mayordomo y hablarle otra vez de lo mío; tendrá, como siempre, buenas palabras, «se proveerá lo que mejor acomode al servicio del rey nuestro señor, sosegáos, tengo vuestra petición en la memoria, si sólo de mí dependiera...» En cualquier caso, no dejaré de rogarle, aunque sea importuno, que yo no tengo familiar en ningún cabildo y sólo mi insistencia tiene que lidiar contra los Molina.

- ¡Vaya aburrimiento! A ver si nos vamos a pasar aquí todo el día. Además me va a entrar la risa viendo al rey y la reina tan serios y tan quietos que parece que ni pestañean. Y lo que ha tardado el 
maestro Velázquez en colocarles, con palabras que sólo al pintor de cámara se consienten: "ese mentón más alto, majestad", "mirad hacia aquel espejo, señora, y juntáos más a vuestro esposo», «ivoto a tal, que os han peinado hoy sin gracia!» $\mathrm{Y}$ sus majestades venga a cumplir las indicaciones de don Diego como los soldados de una parada a la voz de su sargento. Ha querido doña Margarita venir a ver a sus padres y aquí estamos todos como pasmarotes. ¡Nicolás, para quieto y deja en paz al perro que no te está haciendo nada! Si le sigues pisando ladrará y nos van a reprender a los dos. Siempre eres tú el que anda haciendo barrabasadas, que tienes el seso tan de niño como tu cuerpo y no como tus años. Luego me llevo yo parte del capítulo: «iMaribárbola, Maribárbola, estate quieta, que no es hora de chanzas!» Hace una mañana espléndida y mejor estaríamos en el jardín del alcázar que no en el estudio del maestro Velázquez; claro que tampoco ahora estaríamos allí sino en la lección de latines de la infanta, que ella, al fin, algo aprende, pero a mí me parece, tanto "temporis» y "vobiscum», tanto "nuncupo» y "elicio» que es segunda misa diaria pero sin capellán ni comunión, ¡Dios me perdone! Hoy están los reyes con ganas de posar, ique también son ganas! A mí no han de hacerme nunca un retrato, ¡quiá!, pero si don Diego, que anda pintando bufones en palacio y ha retratado a Pablo de Valladolid y al pobre tonto de Calabacillas, me pidiese un día que posara para él, le diría que yo no aguanto quieta más de un rato y que no iba a estar las horas muertas sin rascarme la cabeza o la nariz si me picaran y sin moverme de acá para allá. Pero bueno, a santo de qué me iba a querer pintar a mí nadie; buena compañía soy para la infanta y hasta los reyes gustan de mi presencia y dicen que soy despierta y enseño a doña Margarita más que algunos de sus preceptores; pero no quiso Dios darme presencia que merezca ser expuesta colgada de una pared; no se reiría poco mi buen padre si un día le dijera que el pintor de sus majestades me iba a poner en un lienzo; al honrado Juan Bárbola le faltaría tiempo para correr al figón y contárselo entre risotadas a sus cofrades. Vaya, ahora se ha movido la reina; a ver, lo que yo digo, quién puede hacer de estatua si no es de mármol. Bueno, ya recuperó la postura, la tiene bien aprendida.

- Me parece que el maestro Velázquez no tiene hoy la inspiración a su lado. Hace un buen rato que está como suspenso, dudoso en qué color mojar el pincel. Por lo que veo desde aquí, ni siquiera ha abocetado el cuadro. Mucho se lo piensa hoy; y para eso tiene a los reyes detenidos mientras la antesala de audiencias rebosa de gentes 
que han de ver sin demora al rey. Y la reina; nunca la han pintado junto a su esposo y sin duda que le alegra esta ocasión, pero como no se dé prisa el maestro este cuadro se queda sin nacer. Luego quizá me echen a mí la culpa: «don José, me dirá Velázquez, estoy quejoso de vos; sois el aposentador y no habéis dispuesto el recinto como os indiqué, aquella cortina sobraba, ese lienzo no es el adecuado, aquel otro ¡qué color!» No es cierto; si la inspiración no le faltase, todo estaría a su gusto, pero un artista no va a negar su capacidad de una hora habiendo quien pueda cargar sus culpas. Voy a mis cosas y luego volveré. Para mí que lo mejor que podía hacer don Diego es dejar la sesión para otra jornada; hoy no creo que le salga bien ni un trazo.

- La reina me mira, ¿querrá indicarme algo? No, no; está mirando a la infanta. Está bellísima su majestad. ¡Qué gran suerte ser menina de doña Margarita! No cambiaba yo mi posición por la de ninguna de las muchachas de mi familia. Bien es cierto que ser un Velasco en la corte no es poca cosa, pero de nuestro apellido gozan los hombres y lo llevan como plumas en sus chambergos. Las mujeres entrarán por matrimonio en otras casas y serán lo que sean sus esposos, y allí se va el Velasco con la dote. ¿Me mira ahora la reina? Ahora sí. ¿Quién puede presumir de estar más cerca de la reina, excepción de sus damas y camareras, que nosotras, que por estar junto a su hija preferida entramos y salimos por los aposentos reales con más soltura que por los de nuestros padres? Menina de la infanta tengo por más título que el solo de mi apellido. Otra vez parece que se fija en mí; sin duda quiere algo y no lo dice por no descomponer la postura.

- Pintor de cámara soy y pinto de encargo y por tanto alzado, pero a fe mía que no me apetece ni poco ni mucho retratar hoy a sus majestades. Otras veces lo he hecho y más aún lo haré en lo venidero, no tendrán queja. Pero siempre ante un lienzo en blanco he visto dibujado aquello que luego plasmaré para que lo vean todos. Hoy no. No consigo que se me aparezca la composición. El rey y la reina, juntos, irradiando señorío y majestad, y sin embargo... Sí, ahora estoy seguro; es la mirada de la reina lo que me desconcierta. Don Felipe está como otras veces, como siempre, hierático y un tanto ido de lo que le rodea; podría copiar su rostro de algún otro retrato y nadie sino yo conocería que es imitación y no toma del natural. Pero doña Mariana... ¿Es la reina quien tengo delante o es una mujer que mira con dulzura a su hija? Esa mirada, jay si yo pudiera captar con mis pinceles esa mirada!, si supiera dar a su re- 
trato el inapreciable toque de color o de sombra y luz que señalara esa sutil diferencia entre la mirada de una reina y la de una madre. Habría de mover mi mano el espíritu divino y aun así fuera difícil. ¿Qué verán sus ojos y, sobre todo, cómo nos verán a los que aquí estamos pues somos a quienes mira? Si yo pudiera aprehender la imagen que se refleja en su pupila... Y ¿por qué no he de poder? ¡Ea!, he de pintar en un cuadro ya que no la virtud de una mirada, sí la visión que la provoca. Entremos todos en él y piérdase la noción de espacio; el aquí y el allá se han de confundir; ¿quién mira a quién?, ¿cuál es el color de una mirada? Mire la reina, mire el rey $\mathrm{y}$ mirémosles nosotros; todo es uno y quien mira es visto y a quien se ve nos ve; he de hacer una obra en la que no importe tanto lo que aparece ante los ojos como el que un mundo entero existe porque hay ojos que lo ven. Empiezo, pues, y Dios con todos.

\title{
Soñé que tú me llevabas
}

\author{
«Soñé que tú me llevabas \\ por una blanca vereda, \\ en medio del campo verde, \\ hacia el azul de las sierras, \\ hacia los montes azules, \\ una mañana serena.»
}

En la ciudad donde vivo, vieja, pequeña, episcopal, cargada de historia hasta la pesadumbre, hay tiempo de sobra para hablar con el vecino y el amigo y también para ocuparlo en ensoñaciones si el natural de cada uno es de los proclives a perderse en el mundo de la fantasía. Se encuentra, por añadidura, enclavada en una tierra, Galicia, donde las consejas de aparecidos y el relato de viajes fabulosos están en la memoria y en la conversación habitual de sus habitantes hasta el punto de que llega a borrarse el límite siempre tenue entre lo que es recuerdo de vigilia y evocación de sueño. Quiero que estos apuntes geográficos sirvan para que quien me lea no me tenga por alucinado sino por hijo de mi tierra, con la fantasía embebida en la sangre de muchas generaciones como un fluido más que corre por las venas sin que puedan separarse una de otra so pena de sufrir una grave anemia incompatible con la vida.

En mi ciudad cae el orballo durante meses como ejemplo de eternidades, pero también sabe lucir el sol y entonces la brisa trae hasta sus calles laberínticas el aroma de otro agua, el olor del mar que no está muy 
lejos, apenas al otro lado de las montañas que la vigilan por el norte. En cualquier caso, el ambiente es siempre húmedo y de vez en vez el cuerpo pide escaparse a tierras de secarral o cuando menos pasar unas jornadas en otro lugar donde el sol sea más complaciente y seque los huesos que también se pueden oxidar como las rejerías de la ciudad y hasta las de su imponente catedral. Cuenta también en esta vocación mía andariega, estoy seguro, el que en mi ciudad se tenga especial devoción a dos figuras de santos peregrinos. Uno es san Roque, que tiene asiento numerario en el canon hagiográfico y cuya imagen con bordón, esclavina y vieiras, se saca en solemne procesión en su festividad de agosto por las calles empinadas y serpenteantes que ascienden desde la plaza de la catedral hasta los barrios altos, para seguir luego el camino contrario, siempre entre dos filas de fervorosos vecinos. La otra se conoce allá como el Conde Santo, don Osorio, un hombre que vivió en la Edad Media con fama de santidad entre sus gentes, que guerreó contra invasores moros y normandos y que luego marchó de palmero a Jerusalén para fundar a su vuelta un gran monasterio al que se va de romería primaveral desde todos los rincones de Galicia.

Por eso un par de veces al año, como si fuese una medicina, suelo bajar a los caminos de Castilla o Andalucía y aprovecho entonces para hacer rutas que llamo yo literarias porque me gusta proyectarlas según las lecturas que haya acumulado en los meses anteriores. Una manía como otra cualquiera pero que a mí me permite disfrutar del viaje desde mucho antes de realizarlo físicamente.

Hace poco me decidí por Soria. Era primavera y durante el mojado invierno transcurrido había manoseado mis viejos libros de Machado; con los buenos libros sucede que la relectura siempre consigue mejorarlos y que no hay ocasión en que no salte ante nuestros ojos una nueva perla que en la anterior nos quedó a trasmano o se soslayó porque teníamos la atención puesta en otros derroteros. Así fue también ahora. Entre los cientos de versos que componen la edición que manejo de las Poesías completas machadianas -un volumen de Austral desencuadernado por el uso- unos atraparon mi ánimo hasta convertirse en obsesión el volver una vez tras otra sobre ellos; son aquellos que comienzan con las palabras «Soñé que tú me llevabas».

Nació, pues, el deseo, que se fue transformando paulatinamente en necesidad, de buscar por las tierras sorianas esa blanca vereda, esas sierras y montes azules y aquel verde campo por el que anduvo el bueno de don Antonio soñando compañías ya perdidas para siempre. En Soria habré estado veinte veces, pero en esto los paisajes se asemejan a los libros -páginas del libro de la naturaleza los llamó alguien, poeta también 
aun cuando ni él lo sospechara-: en que siendo iguales a sí mismos los vemos diferentes según sean los ojos con que los miramos, y así nos pueden parecer siempre nuevos y nunca se acaba el placer de su contemplación por más que repitamos la visita. Esto ya lo descubrieron con sus pinceles los impresionistas y con sus palabras nuestros escritores del noventa y ocho.

Mi alma gallega, a la que no puedo sustraerme, me llevó para comenzar mi camino a las estribaciones del Monte de las Ánimas y desde allí, a un paso, al sobrecogedor claustro de san Juan de Duero, un lugar donde, debí suponerlo, toda aparición sobrenatural es posible y hasta esperable. Con mi mochila al hombro «ligero de equipaje»-deambulé por sus cuatro naves destechadas, por su centro abierto al cielo castellano de un azul que parece hablar a los hombres para recordarles su nimiedad al mismo tiempo que abrirles sus ansias de infinitud, y me senté en la base de la columnata occidental, con el monte frente a mí y el rumor del río a mis espaldas. Era uno de esos días largos y luminosos de la primavera corrida y las primeras horas de la tarde llenaban de claridad todo el recinto. Muy cerca, el Duero bajaba crecido por el deshielo de Urbión y parecía lamer como con rabia los tajamares del puente. Si no fuera demasiado tópico diría que luz y sonido se acordaban en un relajante concierto que hacía al viajero perder por momentos la noción de realidad. Así pasó lo que pasó.

Por entre la arquería románica entreví cinco figuras. Con esa omnisciencia de la que todos gozamos en los sueños, los identifiqué sin titubeos. Eran Ramón, Miguel, José, Pío y Antonio. En otras circunstancias y habiendo sido yo de otra nación me hubiese sobresaltado. Pero en Galicia cualquiera sabe desde chiquillo de la existencia de la Santa Compaña y la teme a la par que la espera en cada encrucijada. Y también tenemos allí, en el cabo de Ortigueira, el santuario de san Andrés de Teixido a donde acuden con su cuerpo metamorfoseado las almas de quienes no hicieron la romería de vivos. De modo que sin el menor aspaviento del ánimo me dije: estos cinco seguro que vienen de promesa o a pagar una deuda y a algún sitio habrán de ir; voy tras ellos, y Dios me asista.

Los cinco aparecidos llegaban ciertamente desde lugares distintos y alejados entre sí, pero no intercambiaron ningún saludo y tampoco, a lo que pude observar, se percataron de mi presencia como intruso en tan peculiar cofradía. La cita debía de estar muy concertada y aquellos personajes de figura tan dispar apenas se entretuvieron unos instantes en mirarse los unos a los otros y en hacer cada cual un gesto de asentimiento con la cabeza, como quien dice sin palabras que todo está en orden. Pensé yo que quizá fueran espíritus mudos porque, al fin y al cabo, para qué ne- 
cesitan los trasgos ejercitar la lengua si podrían entenderse en un idioma sin vocablos y hasta sin sonido. Pero meditando en ello caí en la cuenta de que nunca oí contar un relato de espectros en el que éstos no hicieran uso de palabras humanas e inteligibles, aunque quizá cargadas de misterio, para comunicarse entre sí y con los mortales. Así pues, lo que tenía que hacer era aguzar los oídos y estar atento al más sutil movimiento del aire porque sin duda en él iría prendido el lenguaje de quienes ya tenía por compañeros de aventura.

Y, en efecto, hablaron; o con más precisión, hablaban casi siempre cuatro, y el quinto, Antonio, escuchaba lo que los otros tenían que decir. A Ramón era a quien con más facilidad se le identificaba, tanto por el tono más alto y casi declamatorio que se gastaba como por el peculiar ceceo tan chocante con la solemnidad de su parlamento. Su figura, además, era inconfundible, como extraída o recortada de una de esas antiguas fotografías con que se ilustran las sobrecubiertas de sus obras: una pelambrera alucinada y una larga y fosca barba que apenas dejan entrever unos ojillos inquietos y vivarachos asomados al cristal de unas antiparras; el resto, un cuerpo larguirucho y que se adivina con pocas carnes embutido en un traje negro lleno de brillos y con hilachas en cada costura y en cada borde; y la manga izquierda de la chaqueta plegada sobre sí misma pero de tal modo que más que signo de manquera parece condecoración de combatiente. En ese punto me cupo una duda y es la de si los fantasmas humanos conservan sus invalideces cuando regresan al mundo para ocuparse de algún asunto que dejaron aquí pendiente. Pero debe de ser así por cuanto en el libro Almas en pena y visión que tienen de ellas los mortales, del sabio morabito Omar al Haif, que es para estas cuestiones de aparecidos como el evangelio, se nos narra un sinfín de casos en los que seres que vienen del más allá, de encargo o por deudas sin pagar, lo hacen no sólo con su indumentaria habitual y sus menguas físicas si las tuvieron antes del tránsito, sino hasta con los más pequeños detalles de su anatomía como cicatrices o verrugas; y todo ello precisamente para poder ser reconocidos sin lugar a dudas. Menciona por ejemplo el autor árabe el caso de un hijo bastardo del caíd de Alejandría que habiendo muerto decapitado en Bagdad acudió sin cabeza a su ciudad natal para satisfacer una deuda de juego y fue reconocido por su padre y por su acreedor porque conservaba un lunar estrellado y piloso sobre la clavícula derecha que era muy popular en los baños alejandrinos.

Decía Ramón: «A mí no me duelen prendas y admito mi falta como he admitido antes tantas otras. Lo cierto es que fui cayendo de error en error y apenas me levantaba de uno cuando ya estaba metido de hoz y coz en el siguiente." 
Miguel parecía refunfuñar y movía la cabeza de un lado a otro. Llevaba el pelo cano muy corto y por su vestimenta se le podría confundir con un clérigo, algo que a él en el fondo no le hubiera disgustado aunque fuera capaz de rebatirle sus argumentos al mismísimo diablo si éste le mencionase tal parecido. «Yo-iba diciendo- siempre la puse en un lugar de privilegio pero, eso también es verdad, casi nunca la concedí demasiado protagonismo. Ella detrás, en el fortín del hogar, cuidando la casa y la prole y siendo el símbolo de lo permanente y lo fructífero. Pero no escatimé los elogios y muchos de mis personajes más recios son ellas.»

La comitiva espectral, con su clandestino escudero, había llegado a la altura de san Polo, el viejo recinto templario que monta guardia desde hace siglos a uno de los paisajes más sugestivos de la vetusta ciudad castellana. Hace mucho tiempo que sólo queda en pie una mínima parte de lo que hubo de ser una gran construcción de los frailes militares, pero entre ese poco está un arco con la piedra semioculta por la hiedra enredadera que parece puesto allí como una escenografía medieval o romántica; cruzarlo se convierte en un rito de paso y así debieron entenderlo los cinco hombres porque se detuvieron en su umbral por unos instantes y echaron la mirada atrás, hacia el camino que ya habían hecho, de forma tan penetrante y rápida que apenas tuve tiempo de ocultarme con el tronco de un grueso olmo, aunque seguramente no me hubiesen descubierto porque para mí que sus ojos no buscaban la insignificancia de un ser como yo sino que escrutaban la invisibilidad del pasado.

$\mathrm{Al}$ otro lado del arco de san Polo, ya se sabe, comienza el paseo de san Saturio, antaño lugar de recogimiento peripatético y hoy punto de cita de un buen número de sorianos y de la mayoría de los visitantes ocasionales de la ciudad. Lugar cargado de resonancias machadianas como pocos que está ahora jalonado con estelas de piedra en las que figuran escritos algunos de los versos más conocidos del poeta, aquellos que se saben de corrido hasta los niños de escuela.

Mis personajes eligieron el lado del paseo que se desploma hacia el río y cada poco rato se detenían en el antepecho dejando ir la vista hasta las aguas que un suave vientecillo rizaba como un remedo del mar. Demostraban bien a las claras no tener ninguna prisa por llegar a su destino cualquiera que fuese éste, algo que aún era para mí una incógnita.

Antonio, el más encorvado de los cinco, como si le pesara un mundo sobre los hombros, se apoyó en el murete cuyas piedras de granito están suaves y brillantes de tanto y tanto roce de manos y cuerpos de paseantes. No hablaba para los demás sino para sí; desgranaba sus propios versos:

«Sentí tu mano en la mía,

tu mano de compañera, 
tu voz de niña en mi oido

como una campana nueva, como una campana virgen

de un alba de primavera.

¡Eran tu voz y tu mano,

en sueños tan verdaderas!...»

A su lado, José y Pío parecían estar a otra cosa. Los dos distraían sus miradas en el entorno como tomando apunte mental para llevar luego a un papel la descripción minuciosa de cada detalle. Sin embargo, sí escuchaban a su compañero porque cuando éste calló se volvieron hacia él al unísono esperando quizá que continuase con su evocación de aquel soñado paseo tomando de la mano a una mujer.

José fue el primero en romper el silencio que se había establecido: «Cae la tarde; sigamos.»

Para mi sorpresa y sobresalto los cinco no siguieron hacia la ermita de san Saturio que estaba ya a la vista y ni siquiera hacia el nuevo puente que salva el Duero a aquella altura de la carretera, sino que bajaron directamente hacia el río con la inequívoca intención de cruzarlo en dirección a la ciudad que baja a buscar la orilla opuesta. Me lancé, pues, a la carrera para alcanzar yo el puente y no perderlos habiendo llegado hasta allí en tan mágica vecindad. Los vi aproximarse a la ribera y, como si tal cosa, empezar a discurrir sobre las aguas. La brisa, viniéndoles de frente, deshacía una parte de sus figuras en retazos vaporosos, como lo hace cuando sopla sobre la niebla que cubre un río en las horas del amanecer. Conformaban una extraña y sobrecogedora procesión fluvial que tenía algo de esos cuadros en que los pintores del romanticismo han querido plasmar los relatos de sus coetáneos con fantasmagóricas letanías cruzando los campos y las aguas neblinosas camino de ritos justicieros o de expiación.

$\mathrm{Y}$ viéndolos desde mi balconada del puente me dio por mirarles los pies y me extrañó que en ninguno fuesen perceptibles. Y no porque los llevaran sumidos en el agua que en ese momento atravesaban, sino que carecían de ellos y sus figura se movían como a una cuarta de altura sobre el nivel del río. Hasta entonces no me había percatado de ese detalle que más tarde pude confirmar cuando llegaron a tierra. Aquellos espíritus -y quizá todos, pero mi experiencia era en esto bien menguada- no tenían, efectivamente, pies; cosa que de inmediato achaqué a que siendo meros espíritus, aunque de apariencia humana en todo lo demás que se alcanzaba a ver, no necesitaban de pies para moverse, y que esta parte del cuerpo en el hombre no tiene otra misión que sustentarlo vertical y 
darle apoyo en el caminar. Cualquier otra porción de la anatomía visible, brazos, manos, y no digamos la cara, cumple una función comunicadora con los demás y a su través se trasluce gran parte si no toda la personalidad del individuo, mientras que piernas y pies sólo son apoyatura física y medio de transporte.

Soria tiene por aquel lado de su caserío una subida escarpada a mitad de la cual están mortecinos y arrumbados los restos de un castillo. Imaginé que hasta allí iríamos a parar en la peregrinación aunque seguía sin hacerme idea de con qué fin mis cinco caballeros venían desde tan lejos para terminar entre sillares asolados de una fortaleza que, según mi memoria, no guardaba en su pasado ningún dato de interés y menos todavía nada con poder de convocatoria para cinco sujetos tan dispares como los ahora reunidos ante mi cada vez más intrigada curiosidad.

Pero nuevamente me equivoqué: no era el castillo su destino. Dejando el ruinoso solar a su derecha, enfilaron hacia un alto muro de mampostería, encalado a trozos, que se encuentra más al norte siguiendo el curso del río hacia su nacimiento. Por encima del muro y de su desconchado tejaroz, el viajero que se acerca puede ver la negrura enhiesta de unos cipreses: es el cementerio de El Espino, donde reposan desde hace más de un siglo los sorianos.

A pesar de mi ya declarada condición de gallego formado en un ambiente cultural donde la muerte y todo lo que la rodea es tratado confianzudamente, no pude reprimir el repeluzno que me sacudió el cuerpo de arriba abajo y estuve tentado de dejar allí mismo la insensata carrera que comencé, ya no sabía cuándo, en el claustro de san Juan. Lo que empezó como aventura de ensoñación literaria tomaba visos de convertirse en un episodio macabro en el que yo mismo, y eso me provocaba sudores helados, podía terminar por ser obligado protagonista.

Me paré en seco mientras ellos traspasaban la verja entreabierta del camposanto. Tenía que pensar mi próximo movimiento.

En el volumen Guía de España con detallada relación de sus tierras y mares para uso de espíritus y trasgos viajeros de fray Andrés de Écija O.S.H., publicado en Amberes en 1588, el año de la Invencible, que compré en una librería de lance a espaldas de la Catedral Primada de Toledo y que, según se conoce por su ex libris en una de las guardas, perteneció al canónigo magistral don Francisco Peñalva y Díaz, se mencionan como principales deudas que hacen regresar del más allá a los muertos las de honor, las de amor y las de juego, amén de la promesa no cumplida de peregrinar a algún santuario apostólico o de santo de los considerados mayores, es decir, de los de festividad y misa cantada o por lo menos doblada. 


\begin{abstract}
Ahora bien, ¿cuál de estos motivos o cuál otro tenía su lugar de asiento en El Espino soriano? Tenía razón aquel que dijo que una de las mayores fuerzas de la naturaleza es la curiosidad. En mí, desde luego, se sobrepuso a cualquier otra consideración incluido el miedo que no deja de ser otro gran condicionante de los actos humanos. Y avancé, avancé despacio, pasito a paso, que el valor no se improvisa ni aun con el acicate de esa curiosidad. Crucé la cancela con un cosquilleo en el cogote que no me dejaba desde que avisté la punta de los cipreses. Era además esa hora que dicen en mi tierra de entre lusco y fusco, cuando las sombras de los objetos y de las personas comienzan a perder sus contornos y a sumirse en la sombra general de la noche; aún no la hora de ánimas, pero sí su preludio.
\end{abstract}

Deambulé un rato por calles de gravilla, otras de césped y alguna de asfalto, todas de fúnebres arcenes, con esa tristeza que hizo exclamar al poeta. «Dios mío, qué solos se quedan los muertos!». Unos pocos vencejos agotaban su último vuelo del día allá en lo alto mientras más abajo tomaban el relevo del aire los murciélagos de la anochecida. Un espeso y agobiante silencio, sólo roto intermitentemente por el agudo chillido de los pájaros en retirada, lo enseñoreaba todo y hasta me parecía que me calaba la piel y la carne aposentándose en mis entrañas y en mis huesos; pensamiento funeral que he experimentado en otras ocasiones cuando he visitado cementerios rurales, de esos en los que no es nada difícil comprender las palabras del memento mori porque se integran sin solución de continuidad con la tierra, con el humus originario y terminal.

$\mathrm{Al}$ fin los volví a encontrar. Estaban alrededor de una tumba sobre cuya piedra habían depositado un ramillete de flores silvestres: malvas, retamas, jaramagos, amapolas, en un abigarrado conjunto de los colores de la primavera, esos mismos colores que vistos en los campos son como una exageración de Dios. La vieja lápida había adquirido con el tiempo una pátina grisácea aunque en sus junturas verdeaba una fina cenefa de musgo. Costaba esfuerzo leer las letras del epitafio, pero un nombre destelló ante mis ojos que miraban la escena desde una docena de pasos de distancia: Leonor.

"Vive, esperanza, iquién sabe

lo que se traga la tierra!»

Entonces, de pronto, me parecieron los cinco un grupo de viejos cansados, llegados al límite de una existencia que en su caso iba más allá de una vida larga y azacaneada de sinsabores y frustraciones. Y perdido ya el último atisbo de temor a la vez que embargado por un tremendo respeto hacia ellos, me acerqué hasta su misma intimidad, para ser el sex- 
to en aquel ritual que culminaba, según creí, el misterioso peregrinaje de esa tarde de fantasmagoría y ensueño.

Ninguno levantó la cabeza que todos tenían inclinada en ademán de profundo recogimiento. Me pareció, sí, que me miraban por el rabillo de sus ojos tristes y hasta quise adivinar que Antonio, quizá también José, esbozaban algo parecido a una sonrisa de agradecimiento por mi inesperada compañía. Es posible que en ese momento sintieran levemente atenuada su ultraterrenal soledad.

Como quiera que fuese, debieron sentir la necesidad de compartir conmigo lo que bullía en el hondón de sus conciencias y unas palabras, musitadas más que dichas en voz alta y que no sabría decir de cuál de los cinco partieron, me llegaron a los oídos sin que fuese capaz yo mismo de alzar la vista para identificar al autor o los autores de la confidencia. Las letras de Leonor me imantaban y hubiese pensado entonces que ni siquiera la sangre se movía por mis venas, cuanto menos un solo músculo. Todo mi ser, en una suerte especial de minimalización como la que dicen alcanzar los maestros del yoga, estaba localizado en los dos sentidos de la vista y el oído. Leonor y aquella voz.

«Este es un acto de desagravio, un reconocimiento de culpas y una petición de indulgencia. Leonor es la mujer, no una mujer singular. Es una deuda que arrastra nuestra generación: la de no haber sabido o querido poner a la mujer como eje de nuestra literatura; o al menos como uno de sus pilares esenciales. La literatura medieval brotó alrededor del amor cortés en Provenza o del amor más cercano en la poesía andalusí y castellana; el Renacimiento tiene en Beatriz y en Laura sus cimas de inspiración; después, la mujer está presente en todos los textos de los siglos de oro español, inglés o francés; el Romanticismo no se entendería sin la constante referencia a una mujer amada. Y nosotros la olvidamos.

》Cierto que en nuestras obras aparecen muchas mujeres; no podía ser de otro modo cuando hemos pretendido hacer un retablo del alma humana, hemos buceado y hasta escarbado de forma inmisericorde en todos los modos de vivir, de pensar, de amar y de soñar del hombre. Pero nos guiábamos con otras brújulas, cada cual la suya, y ninguna apuntaba al norte de la mujer como absoluto. Miguel la hace recia, con la maternidad como objetivo y como gloriosa misión en la vida, y cuando esa función se frustra, como en Tula, se desborda la fuerza maternal en otras pasiones. Pío lleva a sus páginas mujeres que comparten la acción varonil pero pasan a un segundo plano cuando aquélla se torna dramática o aventurera. Ramón imaginó a niña Chole como un vendaval en el que prender la pasión de los hombres, pero poco más. En José la mujer es un retrato está- 
tico que sabe dibujar con preciosas pinceladas, pero que nunca llena el conjunto y ni siquiera lo suele presidir.

»Ahora ya sabes por qué estamos aquí. Le debíamos a Leonor un instante al menos de entre toda la eternidad. Desde luego nuestra época, la que influyó en nuestros intereses a la hora de escribir, no era muy propicia, en esta España que a todos nos dolía como sólo alcanzó a decir Miguel, para embelesarse con seres ideales. Otros problemas acuciaban a la sociedad y nosotros nos propusimos, si no darles remedio, que eso escapaba de las posibilidades de quienes no tenían otra fuerza que su pluma, sí encontrarles la razón en los entresijos del alma española y sugerir acaso una luz de esperanza. También en esto cada uno fue por una senda distinta; quien intentó el camino derecho aun rompiendo montañas que al fin se demostrarían insalvables; quien prefirió los congostos o las trochas del monte. Y en ese caminar no supimos ver la Beatriz que guió al Dante. Sólo Antonio columbró con Leonor a quien ha sido en toda la historia de los hombres su principal y posiblemente su único conductor: la mujer.»

Me quedé solo. Quizá siempre estuve solo; no lo sé. Ya era de noche y busqué cobijo en la ciudad; a la mañana siguiente volví para mi tierra umbrosa y húmeda todavía en esa época del año. El regreso de un viaje es lo que da auténtico sentido a éste; si no se volviera al punto de partida, a rumiar lo visto y vivido, viajar sería nada más que moverse de sitio y no una actividad enriquecedora del espíritu. Mi paisano Licerio de Lemos, que era por mitades matemático y filósofo pero que ejercía de maestro de escuela, publicó de su bolsillo un libro titulado $E l$ mundo en mi chimenea en el que conjuga hábilmente los principios geométricos con el resto de los saberes humanos, y en sus páginas, que nos regaló a los amigos unas navidades, dice que viajar es moverse en una circunferencia o en muchas de distinto radio, pero que a todas quien al final las define es el centro, ese puntito que él situaba justamente entre los morillos de su chimenea. Yo estoy del todo de acuerdo con Licerio y también pienso que de las potencias del alma la principal es la memoria que por algo figura la primera. Mas llegado a este convencimiento y cuando he regresado del viaje imaginario o cierto que acabo de contar, tengo necesariamente que hacer mías aquellas palabras de mi reciente amigo a orillas del Duero:

«De toda la memoria, sólo vale

el don preclaro de evocar los sueños.»

\section{Al caer la tarde}

A cada paso de los porteadores un dolor. A cada traspié, un ramalazo casi insufrible que le recorría desde la pierna hasta las sienes y le hacía 
morderse los labios y crispar los puños. Los dos meses que había durado el viaje desde Laredo a Jarandilla no fueron tan penosos como esa corta jornada para llegar a Yuste. En aquellos dos meses se habían sucedido además las prolongadas estancias en uno $\mathrm{u}$ otro de los muchos palacios que los Grandes de España ponían a su disposición en cada etapa del camino. Los festejos eran casi continuos y la compañía nunca faltaba así como la buena mesa, surtida de comidas fuertes, salazones y carnes rojas sobre todo, y vino añejo como eran de su gusto y del disgusto de sus médicos. Luego, dos meses más en el magnífico palacio del conde de Oropesa en Jarandilla mientras terminaban de acondicionar las dependencias del monasterio jerónimo bajo la dirección de su fiel mayordomo Quijada. Era tiempo de invierno y se acercaba el día en que habría de cumplir cincuenta y siete años. ¡Santo Dios, qué viejo se sentía! Y, sin embargo ¡cuántas cosas quisiera hacer aún! Su vida entera había sido un constante ir y venir, una perpetua actividad que agotaba a cuantos le rodeaban y debían obedecer sus órdenes o sus caprichos. Mas ahora el cansado era él y de este viaje, por propia decisión, no habría regreso.

En la sierra de Gredos, cuyas cumbres parecía que se podían tocar con los dedos en las mañanas claras del invierno extremeño, la nieve desde las cimas se derramaba hasta los mismos bordes del río que se crecía con esa vecindad. No obstante, la blancura no era absoluta: aquí y allá sobresalían por las laderas manchones oscuros de robles, encinas y algún pinarejo que aguantaban la heladera con un estoicismo vegetal que seguramente estaba emparentado en los arcanos de la naturaleza con la reciedumbre de las gentes de esa misma tierra, capaces, bien lo sabía él, de los mayores sacrificios y austeridades; un entero mundo nuevo le habían entregado sufriendo lo indecible pero permaneciendo al final firmes como esos árboles.

Unos meses después, apenas se intuye la primavera en el aire que vuela sobre la serranía o se mete impetuoso por sus cortadas y por sus puertos, las orillas del río se van a cubrir de otro blanco, el de los cerezos en flor que lo jalonan; y cuando caigan los pétalos en una nevada fingida vendrá, sin solución de continuidad, la explosión del campo con colores incontables que sorprenden al hombre cada año desde los orígenes de la humanidad. Piornos y jaramagos amarillos, lentiscos con la flor morada enhiesta y casi desafiante, rosales silvestres y espinosos de flores pequeñas pero tupidas, tomillo oloroso, brezo que parece querer formar un tapiz entretejiendo su retorcido tronco y sus amarillas flores con el verdor del suelo; y las jaras; las jaras que aquí en Extremadura son omnipresentes y llenan el aire de su olor penetrante y un poco pegajoso como el haz de sus hojas. La primavera es una exageración de la naturaleza, 


\section{José Ignacio de Arana Amurrio}

una exageración de Dios que abruma el ánimo y lo sume en obligada meditación sobre Su obra. Así lo han entendido siempre los poetas y los místicos y muchos filósofos; y estas tres clases de hombres no faltaron nunca en la proximidad de Carlos aunque no fuesen, ni mucho menos, los peones que él había tenido que utilizar en la mayoría de sus partidas de ajedrez con el mundo por tablero.

Alguna vez, con el dolor se le escapaba un gemido que procuraba amortiguar, pero otras era un grito el que salía de su garganta. Y entonces Quijada se acercaba solícito al lado de la silla de manos, que alguien hubiera podido comparar con un instrumento de tortura si se pensaba que la habían construido para transportar por más de media España a un hombre aviejado y achacoso.

- ¿Qué os sucede, majestad?- preguntaba el mayordomo descorriendo un poco la tela que cubría la ventana.

- ¿Qué me ha de suceder, Quijada? Que estos porteadores parecen malas acémilas y se trastabillan a cada paso.

Las palabras no se dirigían directamente a los cuatro fornidos hombres que sujetaban los varales de la silla, pero ellos bajaron la cabeza como si esperasen que cayera sobre sus pescuezos recios de músculo y renegridos de soles un latigazo. La voz del rey, desde luego, restallaba como la cola de un látigo y además no la habían oído antes porque fueron elegidos para esta última etapa entre los criados del de Oropesa sustituyendo a los que anteriormente se turnaban en ese menester. Sin duda, algún palo se iban a llevar. Pero por el contrario fue la también enérgica pero mucho más calmada voz de don Luis de Quijada la que oyeron a continuación.

- ¡Ea, muchachos, mirad dónde ponéis los pies! Por peores trochas habréis andado y tampoco la carga es tan pesada aunque sea la persona del mayor Señor que ha conocido la historia. Esmeráos en la caminata y si el suelo es áspero hacéos cuenta de que sois cuatro nobles señores del Imperio que llevan a su emperador por los patios y las gradas de un palacio. Tiento, pues, y adelante.

Y Quijada, que se había apeado del caballo, acompasaba su caminar al de la silla dispuesto a distraer con su conversación los amargores de su rey. Siempre hubo entre los dos hombres, situados por la vida a tan gran distancia jerárquica, una especial comunicación y confianza. Para don Luis Méndez de Quijada, mayordomo del César Carlos desde hacía ya muchos años, éste era la figura más alta, después de Dios, a quien se podía servir; y en ese servicio había consumido gran parte de su existen- 
cia hasta el punto de seguirle por toda Europa y dejar mucho tiempo sola a su esposa Magdalena de Ulloa en sus tierras vallisoletanas de Villagarcía, y hasta de confiarle a ésta un encargo singularísimo del que hemos de volver a hablar.

Para Carlos, Señor natural de la mitad del orbe, Quijada había sido uno de los pocos amigos en quien descargar las ocultas cuitas que también se agazapan en el pecho de los más grandes hombres. El mayordomo, al contrario de tantos otros, jamás fue servil sino servicial, nunca calló un comentario sobre alguna cuestión que Carlos le propusiera y, menos aún, algo que el César hubiera detestado, almibaró jamás con palabras palaciegas y cobardes la dureza de una crítica si a su sentir debía mostrar su oposición al juicio del rey todopoderoso. Confidente, consejero, fidelísimo brazo ejecutor de muy delicadas gestiones que atañían a lo más íntimo de la vida del emperador, éste tenía a don Luis como el primero en la muy corta nómina de personas a las que abrir su corazón sin el menor recelo.

Quijada se fijó en unos pliegos que había en el estrecho asiento junto al rey y que no parecían en absoluto documentos oficiales de los que siempre iba Carlos ojeando y estudiando en todos sus desplazamientos. Éstos le parecieron papeles en que con letra grande estaban escritas algo así como cortas estrofas de algún poema; pero en su discreción apartó enseguida los ojos de aquel sitio aunque no con la suficiente rapidez para que Carlos no hubiese notado la dirección de la mirada y el gesto de sorpresa. Cogió los papeles y los asomó por la ventanilla hacia el mayordomo.

- Mira, Quijada, son versos. La otra mañana en Jarandilla, antes de la misa de alba, me quise confesar y allí sólo estaba el capellán del conde, un hombre con el que apenas había cruzado unas pocas palabras durante estos dos meses porque el pobre se debía de sentir acobardado ante los clérigos de mi séquito. El caso es que ese cura es un hombre singular y me parece que con muchos más conocimientos de lo humano y lo divino de los que suelen tener la mayoría de los que uno se encuentra por ahí. Unos te hablan en confesión con tal sarta de palabrería que de no ser por el respeto al sacramento les diese con gusto una patada en sus grandes traseros; otros se acoquinan porque es el rey el penitente y no parece sino que te elogiaran los pecados que has cometido; unos, necios; otros, rastracueros. Pero este don Manuel no es ni una cosa ni otra. El día que me confesé con él estaba yo más mustio de lo que últimamente acostumbro y debí contarle mis cuitas de espíritu de algún modo especial. Al finalizar no me soltó ningún sermón, ni siquiera me puso 
de penitencia una ristra de pater noster. No; se hurgó bajó el hábito y me entregó estos pliegos: "Leedlos, Señor, me dijo, y meditadlos. No los escribió un clérigo sino alguien que buscaba alivio a una pesadumbre parecida a la vuestra. Os darán qué pensar, pero también encontrareis en ellos más alivio que en lo que yo pudiera deciros ahora".

"Y aquí los tienes, Luis, no me he desprendido de ellos en tres días, los he leído de cabo a rabo unas cuantas veces y cada una me gustan más. He leído y me han hecho leer muchos libros en mi vida pero no conocía éste. Lo compuso un soldado que sirvió a mis abuelos y que murió luchando por el reino que yo habría de heredar; y yo sin enterarme. Se llama Jorge Manrique y habla de la muerte de su padre que fue Comendador de Santiago.

- Los conozco, Señor. En Castilla son muy populares y mucha gente se sabe de corrido sus estrofas.

- ¿Es cierto eso? Pues yo te digo que valen más que una biblioteca entera. He conocido y me he carteado con los filósofos más señeros de Europa. Sabes de mi devoción por Erasmo de Rotterdam al que invité a venir a España.

- Y sé que escribió a su amigo el gran Tomás Moro diciéndole non placet Hispania.

- Así es; debía pensar que esta tierra era de bárbaros e incultos, algo que, por cierto, opinan muchos en los Países Bajos y de lo que llegaron a convencerme a mí mismo durante años cuando heredé la corona de estos reinos. Desprecié a un hombre como Cisneros que me los había guardado y ni le quise recibir. El pobre murió dicen que de pena por mi desdén. Bien caro pagué mis errores.

- Tampoco los pagaron barato los españoles, si mi permitís decirlo, majestad.

- Cierto, cierto. Se me amotinaron en las Comunidades y tuve que hacer lo que entendí que era justicia.

- Y sin duda lo fue, aunque más de un justo pagó por pecadores, lo que, por otra parte, siempre suele suceder. Pero Vos aplicasteis la justicia; otros habían sido los que encizañaron el ambiente de los reinos.

- Hablas de Chievres y de los otros. ¡Menuda pandilla de imbéciles, de ladrones y de malas personas me rodeaba como consejeros! Yo era un jovenzuelo que nunca había pisado esta tierra de España y me hicieron creer que su corona era un regalo para gozar y repartir en lugar de una responsabilidad para con el solar de lo mejor de 
mi sangre. Pero, jea!, Quijada, dejemos ahora esos recuerdos amargos. Y lee, o mejor dicho, relee, pues dices que ya los conoces, estos versos:

"Ved de cuán poco valor / son las cosas tras que andamos / y corremos, / que en este mundo traidor / aun primero que miramos / las perdemos: / de ellas deshace la edad, / de ellas casos desastrados / que acaecen, I de ellas, por su calidad, I en los más altos estados / desfallecen.

"O estos otros:

"No se os haga tan amarga / la batalla temerosa / que esperáis, / pues otra vida más larga / de la fama gloriosa / acá dejáis. I (aunque esta vida de honor / no es eternal / ni verdadera); / mas, con todo, es mejor / que la otra temporal, / perecedera.

»Hermosas y sabias palabras, ¿no te parece, Luis?

- Sí que lo son. Y se pueden aplicar a cualquiera que tenga anhelo de perdurar en la memoria de los hombres; pero yo creo que a Vos se os ha de recordar por los siglos de los siglos con estas otras- y sin mirar los papeles, Quijada entonó, con la vista fija en algún lugar de la montaña, aquellos que dicen-:

"Amigo de sus amigos, / iqué señor para criados / y parientes! / ¡Qué enemigo de enemigos! / ¡Qué maestro de esforzados / y valientes! / ¡Qué seso para discretos! / ¡Qué gracia para donosos! / ¡Qué razón! / ¡Qué benigno a los sujetos! / ¡A los bravos y dañosos, I qué león!

- ¿Tú crees que será así?, ¿No me odiarán los hombres puesto que a tantos he hecho la guerra, a tantos he sometido y tantos se han tenido que plegar a mi voluntad de grado o por fuerza? Ése es uno de los grandes temores si no el mayor de los que me atenazan el alma y me hacen pasar muchas noches de claro en claro. Mira Luis que cuando se tiene el poder que yo he tenido, todo son zalemas y uno oye en su presencia crujir las espaldas más empingorotadas aunque adivine resquemores y hasta odios cervales en algunas miradas que se escabullen huidizas ante la mía. Mas luego es muy propio de los hombres menguados el querer granjearse honores alanceando moros muertos.

- Señor, no se os pase por la cabeza ese pensamiento. Vuestra labor durante más de cuarenta años de reinado ha sido, más que humana, sagrada. La Universitas Christiana que habéis propugnado y defendido con actitudes, con palabras, con leyes y también, cómo no, con las armas, es la mayor obra que jamás se ha hecho; ni siquiera el Sacro Imperio llegó a tanto porque vuestro esfuerzo ha 
cruzado los mares y dado la vuelta al mundo. ¿Recordáis cuando Vos mismo escribisteis, de vuestro puño y letra, el lema para el blasón del vasco Elcano? : Primum circundediste me. Y en las velas de aquellos navíos, y en las de la Victoria que arribó a Sanlúcar con unos pocos hombres consumidos de hambre y sed, no soplaba sólo el viento de los océanos sino el de una idea universal que se encarna en vuestra persona.

- No me halagues mucho, Quijada, que no es tu estilo.

Una crispación de dolor demudó el rostro de Carlos ante un nuevo traspié de los porteadores. Los papeles que aún sostenía en la mano izquierda casi acabaron en el camino, pero los dedos del mayordomo se apresuraron a cogerlos al vuelo y los depositaron otra vez en el asiento. Una vez que el dolor pareció atenuarse, el César siguió hablando.

- Este Manrique me ha traído al recuerdo a otro poeta también soldado, Garcilaso de la Vega. A ése sí que le conocí pues fue miembro de mi guardia personal, luchó bravamente en Europa y se destacó en Rodas. $\mathrm{Y}$ al igual que Manrique cayó durante un asedio, de un arcabuzazo que le dispararon los malsines desde el adarve de la muralla en Frejús; murió a los pocos días en mi campamento de Niza.

- Tuvo, sin embargo el consuelo de morir con un gran amigo suyo y también buen servidor vuestro a la cabecera: el marqués de Lombay.

- †Ah, Lombay! En pocos generales puse más confianza que en ese Francisco de Borja; hubiese llegado por su valor y el de su familia a lo más alto en la carrera de las armas o en la diplomacia, y lo dejó todo de la noche a la mañana. Cuando me contaron su transformación te juro que no supe si enojarme o emocionarme. El muy bribón debía de estar enamorado de mi Isabel, porque estoy seguro de que era amor lo que sentía por aquella santa mujer que Dios quiso llevarse de mi lado.

Quijada creyó entrever el brillo de unas lágrimas en los ojos de Carlos cuando decía esto. El César giró la cabeza hacia el otro lado como para esconder ese desliz de blandura. Luego de unos segundos de silencio que el mayordomo respetó con reverencia, siguió.

- Abandonó mi servicio por otro más alto y en eso sí tenía razón. Ahora anda guerreando en otro ejército, esa Compañía de Jesús que fundó Ignacio de Loyola, también capitán mío y también herido defendiendo mi señorío sobre Pamplona. A veces, Dios me perdone, he 
llegado a pensar que en el cielo envidian mi ejército y se me llevan a los mejores capitanes; unos con la muerte prematura, otros con la recluta para esos Tercios que no llevan espada ni arcabuz sino sólo palabras. Pero no puedo quejarme. Yo mismo he pretendido ser adalid de la Cristiandad y en Trento esos jesuitas se portaron con tales palabras como los más aguerridos de mis soldados de Mülhberg lo hicieron con sus armas. Es un raro pueblo este de España: brotan de cualquier rincón santos, soldados y poetas y en muchas ocasiones son las tres cosas la misma persona; una trinidad que no he visto en ninguna otra parte de Europa.

- Quizá, Señor, es que para esos frutos hace falta una tierra recia, que parece seca en la superficie pero oculta soterrada la mejor materia prima. El paisaje impresionante y a la vez austero inspira la poesía; la historia, el guerrear porque nunca se ha hecho otra cosa; y en cuanto a la santidad, eso ya es asunto que Dios sabrá por qué la ha sembrado aquí con prodigalidad.

- Tierra recia, dices bien. Tierra donde puede asentar sus pies con seguridad un Imperio; todas podrán tambalearse pero no ésta, y desde aquí siempre será posible empezar de nuevo aunque el mundo entero se venga abajo.

Una ráfaga de viento helado alcanzó a los hombres cuando la comitiva perdió por unos instantes, al cruzar una vaguadilla, el abrigo de la montaña. Carlos se estremeció y Quijada le ayudó a arrebujarse con las pieles de marta que cubrían su espalda y sus rodillas hasta la cintura; tenía los labios un poco morados, la nariz enrojecida y de ella empezaba a gotear una mucosidad transparente que el rey se apresuró a enjugar con el dorso de su guante. Don Luis, sin necesidad de que se lo dijeran, corrió las cortinillas: «Seguiremos charlando» le anunció, sólo con la mirada, el rey. Montó en el caballo que le había seguido dócilmente el largo trecho que caminó junto a la silla y se adelantó hasta la cabecera del cortejo no sin antes dirigirse a los cuatro porteadores.

- ¡Apresurad el paso, pero, por los clavos de Cristo, no sacudáis la silla!

En Yuste los días pasaban monótonos tras las primeras jornadas de ajetreo con la llegada del emperador y mientras éste se acomodaba en la escasa docena de habitaciones que componían el edificio adosado al monasterio y que iban a ser su morada durante lo que le quedase de vida. Los monjes jerónimos, que habían enjambrado hasta allí unos años antes desde el no muy lejano Guadalupe, se mostraban inquietos por tan singular presencia. Cuando tiempo atrás se les comunicó el deseo de 
Carlos de retirarse del mundo entre sus paredes hubo revuelo durante muchas sesiones capitulares. Algunos monjes hicieron protesta de que tal situación iría en detrimento de su soledad monástica porque inevitablemente al César le habría de acompañar un amplio cortejo; otros vieron en ello la ocasión de que el todavía pequeño cenobio prosperara. Pero fueron el prior y los más antiguos de los monjes los que hicieron valer la razón de que la Orden de San Jerónimo, que nunca desde su fundación, hacía más de doscientos años, había salido de las fronteras de Castilla primero y luego de España, fue siempre la preferida por los reyes para su reposo espiritual y ni uno solo, desde Alfonso XI, había dejado de recalar por más o menos tiempo en algunos de sus monasterios: el rey Enrique IV, medio hermano de la abuela del emperador, incluso yacía en la capilla mayor de Guadalupe después de un reinado colmado de tragedias, traiciones y desafectos de casi todos menos de sus monjes jerónimos.

Con todo, durante unas semanas la vida monástica se vio por completo alterada. Un ir y venir continuo de palaciegos y de servidores llenaba a todas horas las estancias monacales y no se respetaba ni la clausura ni el riguroso orden de las Horas que antes regía cada quehacer de la jornada. Pero pronto las cosas volvieron a su ser. En el pequeño palacio quedaron junto al emperador su mayordomo Quijada, el secretario de despacho, el vasco Martín de Gaztelu, los médicos flamencos Mathys y van Male y unos pocos criados de servicio inmediato. Otros sirvientes se acomodaron en un ala del monasterio que desocuparon los monjes; y el resto hubo de irse al vecino pueblo de Cuacos, distante apenas un tercio de legua de las tapias de Yuste. El prior estableció un turno rotatorio entre los monjes para que acompañaran de día y de noche al César y nombró a fray Juan de Regla, un monje que ceceaba ostensiblemente al hablar por su origen andaluz, como su confesor.

Las habitaciones del palacio no las hubiese querido ni para sus criados cualquier rey o noble de mediano pelaje de Europa, tal era su sobriedad rayana en la pobreza tanto en adornos como en comodidades. Pero Carlos se encontraba a gusto en ellas. Orientadas a mediodía, el sol calentaba incluso en invierno; y en los días estivales en que por aquellos pagos suele hacer un calor riguroso, los árboles que proliferaban junto a los muros daban sombra suficiente; sobre todo el nogal de grandioso ramaje que crece al comienzo de la rampa de acceso al porche del palacio. Aún ayudaba más a refrescar el ambiente el riachuelo que corría entre enredaderas y helechales y el amplio aljibe que se construyó justo a los pies del edificio y en donde Carlos se entretenía en pescar carpas y alguna tenca de brillante lomo que luego hacía entregar a los cocineros. En cuan- 


\section{La más alta ocasión}

to a placeres de estancia no echaba nada de menos quien habitó en los más grandes y lujosos palacios del mundo.

A otras cosas, en cambio, no estaba dispuesto a renunciar. Y la más importante de todas era la de estar enterado día a día de cómo sucedían las cosas en los que habían sido sus reinos. Hasta Yuste llegaban, pues, constantes embajadas y mensajeros con nuevas de cada acontecimiento en Castilla, en la frontera con los turcos junto a los Balcanes o en aquellas Indias que ya casi todo el mundo llamaba América. Y Carlos preguntaba hasta los más nimios detalles llegando a agotar a sus interlocutores que ya no sabían qué más contarle. Y sobre todo se interesaba por cómo hacía las cosas su hijo Felipe, todavía en Flandes arreglando los últimos flecos de la onerosa carga heredada; y su hija Juana, gobernadora de los reinos de España en ausencia de su hermano el rey; y de los avatares que corría su propio hermano Fernando al que legó el Imperio aunque todavía no hubiese sido aceptado por todos los Grandes Electores: «Es cuestión de dineros - decía-; en Europa mientras tintinea el oro en la bolsa todos escuchan y luego se deciden por quien más monedas saca y pone sobre la mesa o en la faltriquera de cada cual».

Mas no sólo escuchaba. Algo en su interior, invencible, le hacía querer también mandar, seguir mandando. Había abdicado solemnemente de todas sus prerrogativas, pero el afán, o la costumbre, de mandar se sobreponía a cualquier otra consideración. Gaztelu no daba abasto escribiendo esquelas, largas cartas y detallados memorandos que luego los correos habrían de hacer llegar a las manos de Felipe, de Juana o de Fernando. El caso que éstos hicieran de su contenido, de sus consejos, y más a menudo de sus órdenes, era ya otra cuestión. Por lo general los leían con sumo interés, los meditaban con moderada dedicación y los obedecían o desobedecían con sólo un lánguido recuerdo para el hombre que desde Yuste, perdido entre las fragosidades de una serranía extremeña, creía seguir dominando el mundo. Únicamente Felipe procuraba acomodar su conducta, la pública y aun la privada, a los deseos de su padre y muchas veces se apretaba el papel contra el pecho y hasta lo besaba aunque estuviese rodeado de cortesanos. Pero aun con eso el nuevo rey tomaba sus propias decisiones porque la condición de monarca no era compartible a su juicio y todo el amor y el respeto inmenso que profesaba a su padre habían de quedar en segundo lugar ante su obligación como Señor natural de tantos y tantos hombres a los que ni siquiera vería nunca la cara.

Una de estas decisiones de Felipe causó conmoción en Yuste y todavía años después de morir el emperador se contaban los detalles. A primeros de septiembre de 1557 llegó hasta Yuste, destrozando caballos, un men- 
sajero del rey. Traía la mayor y mejor noticia: las tropas de Felipe habían aplastado a las francesas de Enrique II en San Quintín, a las puertas de la capital, el día 10 de agosto; los franceses habían huido dejando sobre el campo nada menos que ochenta banderas de sus regimientos; el condestable Montmorency, herido, el conde de Montpensier, el mariscal de Saint André y el duque de Longueville, junto con dos mil hombres habían sido hechos prisioneros y más de seis mil soldados franceses quedaron muertos; los soldados españoles apenas habían perdido un centenar de hombres. Una victoria sin precedentes, absoluta; Felipe era dueño de Francia.

Carlos, sin hacer caso del dolor que aquella mañana le atormentaba los huesos y las coyunturas, se levantó como un resorte del sillón: «¿Ha entrado ya mi hijo en París?», preguntó con el rostro enrojecido, los ojos a punto de saltar de las órbitas y la prominente mandíbula de los Augsburgo más llamativa que nunca, como la roda de una galera lanzada al choque en ariete contra la amura de un navío enemigo. «Ha entrado ya mi hijo en París?» Era la culminación de muchos años de guerras que no acababan nunca. Francisco I, al que derrotó en Pavía y tuvo preso, aunque entre consideraciones regias, en Madrid, traicionó luego todas sus promesas por lo más sagrado aliándose hasta con los protestantes y los turcos contra él; el hijo, Enrique II, seguía los pasos del «rey galante»... el muy hideputa. Francia a sus pies y su capital en sus manos: «¿Ha entrado ya mi hijo en París?» El mensajero, que aún resollaba mitad por cansancio y mitad por la majestuosa presencia del gran Carlos a tan sólo unos centímetros de su cara, dudó antes de contestar a la ansiosa pregunta.

- No, majestad. El rey don Felipe se mantiene a las puertas de San Quintín y ha liberado a los prisioneros bajo condición de que no luchen contra él por un plazo de seis meses.

Carlos se dejó caer pesadamente y varios de sus acompañantes, entre ellos, cómo no, Quijada, se abalanzaron para sujetarle porque la impresión era la de que se iba a desplomar al suelo. El color rubicundo de su rostro se había tornado en un instante en cérea palidez; los ojos entrecerrados; el belfo desmayado sobre el pecho dejando abierta la desdentada boca; componiendo todo ello la figura desmadejada de un hombre al que hubieran propinado un descomunal mazazo en la cabeza.

- ¿Cómo es posible eso? ¡Te equivocas o mientes, mentecato!

La apariencia del mensajero no era mejor que la del César pero a él no se dirigía ninguna mirada de los circunstantes. En ese momento su 
mayor deseo era que se abriese la tierra bajo sus pies o cayeran sobre él el cielo o la montaña, pero quedar sepultado. Por unos segundos sólo se oyó en todo el recinto, o eso creía él, el entrechocar tembloroso de los quijotes de su liviana armadura de soldado.

Quijada vino en ayuda del joven y con un gesto le indicó que se retirara, cosa que hizo más corrido que un gozquecillo al que le acaban de dar un puntapié. Tardó en desaparecer de la estancia regia menos que el suspiro que brotó de su pecho al atravesar los cortinajes que hacían las veces de puerta con la antesala de la guardia.

Carlos permanecía en silencio; el único atisbo de vitalidad eran sus puños crispados en los brazales del sillón frailuno y el color amoratado que iban tomando sus nudillos por la presión sobre la madera. Pudieron pasar minutos u horas antes de que el ademán cambiase. Los que estaban allí no sabrían contar el tiempo a pesar de la docena de relojes que había sobre estantes y junto a la gran chimenea; no se atrevían a moverse, tragaban con dificultad la saliva porque todos tenían un nudo en la garganta y como un cuchillo clavado unos en la boca del estómago y otros en el pecho, y se miraban de reojo entre sí esperando que alguno rompiese la tensión con una palabra o con un gesto.

Al final el más decidido fue, como siempre, Quijada; la extrema confianza le favorecía.

- Señor, ¿queréis quedaros solo?, ¿queréis que vengan fray Luis o el médico?

- Solo, -musitó más que dijo Carlos.- Idos todos.

Salieron en taciturna procesión que cerraba el mayordomo quien aún se mantuvo un momento en la puerta mirando a su Señor y moviendo acompasadamente la cabeza de un lado a otro. Era el amigo que mira al amigo en un trance de dolor y se siente solidario hasta la médula de ese pesar. Pero él mejor que nadie sabía que cuando el César quería quedarse solo, y en los últimos meses era cada vez más a menudo, nada ni nadie podía entrar en esa intimidad. El dolor y hasta la rabia, compartidos, parece que son menos gravosos para el hombre; mas aquél no era un hombre cualquiera sino el ungido un día por el Papa el Bolonia para ser el guardián de la cristiandad y del mundo; y semejante privilegio lleva consigo, pensaba don Luis, la contrapartida de estar solo en los momentos más difíciles: nadie a su lado; nadie sobre él sino Dios que habla a los hombres a veces de forma demasiado enigmática para que se le comprenda cuando se necesita.

Aquella primavera de 1558 reventó en la Vera como si nunca fuera a haber otra; y ello era verdad para algunos, pero no lo sabían. Los mismos 
monjes se lo dijeron a Carlos: no recordaban otra igual. Al blanco de los cerezos se unía el azahar de los naranjos y limoneros de la huerta monacal que alcanzaba hasta los mismos umbrales del palacio llenando el ambiente de perfume elaborado por el mejor perfumero; las chiribitas cubrían el suelo hasta donde alcanzaba la vista y las primeras malvas parecían surgir por ensalmo, multiplicadas cada amanecer, de lo que hasta hacía unos días eran secas rastrojeras. El campo saludaba a la nueva estación exponiendo día a día, se diría que hora a hora, lo más bello que atesoraba. El sol, vivo otra vez, contribuía con su luz renacida a la hermosura de los días cada vez más largos, de atardeceres prolongados que se fundían lentamente con la noche y no se truncaban abruptamente en la oscuridad como en el invierno.

A pesar de todo, Carlos sentía frío en los huesos y se arropaba con mantas y con pieles junto a la chimenea que debía permanecer siempre encendida con grandes troncos de encina sobre los morillos que tardaban en consumirse chisporroteando de vez en cuando y soltando una constelación de brasas rojizas y de pavesas grisáceas. Él era consciente de que ese frío no le entraba desde fuera sino que procedía de su mismo interior: «Se me hiela la vida y aquí dentro no se pueden meter braseros ni chimeneas... o quizá sí». Conversaba a ratos, despachaba con Gaztelu cada vez menos, leía mucho, sobre todo libros de filosofía, de teología, incluso algunos para los que sólo él disponía de licencia papal para su lectura, sin olvidar otros de poesía y muy de vez en vez aquellos versos de Jorge Manrique: Despierte el alma dormida, avive el seso y contemple...;pero sobre todo pensaba arrebujado frente al fuego o en el porche de las columnas, dejando que la vista se perdiera a través de caminos imaginados que recorrían España, Italia, Flandes, Alemania, Austria, parando en esta o aquella ciudad, olfateando por encima del olor del azahar o de los rosales el de la pólvorá de las batallas o el de los pebeteros de los grandes salones palaciegos; viendo a mil soldados de rostro tiznado, a mil cortesanos de ricas vestiduras a la moda de cada reino, a mil mujeres hermosas que doblaban la rodilla a su paso dejando que sus escotes hablaran más que sus ojos o sus labios.

Don Luis Quijada acababa de regresar de Villagarcía donde había pasado unas cortas semanas con doña Magdalena y con el chiquillo. Aquel muchacho acababa de cumplir doce años el mismo día de febrero en que Carlos cumplía cincuenta y ocho. Su aún corta vida estaba rodeada de misterio hasta para él mismo. Sólo tres personas conocían la verdad de sus orígenes. Carlos, su hijo Felipe desde hacía poco, y don Luis Quijada. Éste lo había recogido nada más nacer en Ratisbona, fruto de una corta relación entre el ya viudo Carlos y la flamenca Bárbara Blomberg, y por 
encargo del emperador lo tomó desde ese día bajo su cuidado personal. Con el nombre de Jerónimo, Jeromín le llamaban todos sin sospechar su cuna, lo trajo a España a los cinco años y le dispuso alojamiento y custodia en Leganés, muy cerca de Madrid.

Pero como las enseñanzas que allí recibía del cura del pueblo y de la persona a quien don Luis había encomendado el cuidado del niño, el músico flamenco conocido como Francisquín casado con una castellana de Leganés, todos ellos bien ajenos de saber la auténtica personalidad del chaval, no le parecían adecuadas, Quijada decidió llevárselo a su castillo de Villagarcía de Campos. Allí se lo presentó a su esposa como hijo de un alto señor del reino diciéndole que deberían cuidarlo como hijo propio. La buena de doña Magdalena creyó que tal criatura era fruto de algún desliz de su marido, pero se cuidó mucho de manifestar ningún reproche y acogió a Jerónimo como una verdadera madre, algo que el muchacho no olvidaría jamás.

En este viaje don Luis esperaba convencer al César para que permitiera que doña Magdalena viniese hasta Cuacos con el niño y así poder acercar a éste a su padre natural que no lo había vuelto a ver desde que tenía apenas dos años. Creía el fiel Quijada que esa cercanía habría de alegrar la melancolía que cada vez más se apoderaba del ánimo del emperador. De lo que no estaba seguro era de que fuese fácil que Carlos aceptara la propuesta. Por eso se extrañó mucho cuando tras la primera conversación sobre el asunto el emperador le dijo:

- Tráelo este verano y que entre como paje a mi servicio. Así lo tendré más cerca todavía. ¿Cómo está Juan?

- Jerónimo, digo, perdón Señor, vuestro hijo don Juan está muy bien. Crecido, guapo, listo, juguetón como mandan sus años. Digno hijo de su padre.

- Pero no de su madre, a Dios gracias - dijo Carlos con un mohín de burla en el gesto-, que menudo pendón ha resultado la mujer aunque esté a buen recaudo, casada y bien pagada.

Luego Carlos quedó en silencio mirando el cuadro que colgaba en la pared de la estancia frente a él. Era el maravilloso retrato que de la emperatriz Isabel hizo Tiziano; Isabel había muerto cuando el pintor realizó su obra y como no la conoció en vida copió la imagen de otra, ésta sí del natural, que Carlos guardaba en un pequeño estuche que siempre colgaba de su cuello. Desde el lienzo los ojos de Isabel, serenos como toda su figura, parecían devolverle la mirada.

Carlos retiró la vista y la fijó ahora en la punta de sus botas que asomaban por debajo de la gruesa manta, pero siguió en silencio. Sin em- 
bargo, una sonrisa que don Luis conocía muy bien se comenzó a dibujar en su cara. Pasados unos momentos, Quijada se atrevió a preguntar:

- ¿En qué pensáis, majestad?

- En mujeres, Quijada, en mujeres- y al levantar la vista y tropezar con los ojos garzos del mayordomo, del amigo, prosiguió-. Y no me mires así, que pareces tonto y de eso no tienes un pelo. Aunque esta vez te equivocas en lo que estás imaginando o por lo menos en pensar sólo eso.

- Yo, Señor... - comenzó a excusarse el otro.

- Tú, Quijada, me conoces mejor que nadie y a ti no puedo, ni quiero, ocultarte nada. De modo que siéntate y escucha.

El mayordomo acercó una silla al escabel donde Carlos descansaba sus doloridos pies que se adivinaban hinchados aun a través del fino cuero de las botas. No se atrevió a apoyar la espalda y en esa postura incómoda pero a la vez anhelante se dispuso a oír lo que ya suponía que iba a ser una especie de confesión laica. Muchas veces había vivido escenas semejantes y de cada una de ellas habían salido reforzados su admiración y su cariño por el emperador.

- Escucha y calla. Pienso en mujeres, pero no en una determinada sino en muchas, en las que más han influido en mi vida. La mayoría, fíjate, para bien. En eso también he tenido suerte. Y ahora, después de meses recordando como un penitente mis malas acciones, me ha dado por traer a la memoria los buenos momentos y en muchos de ellos, desde luego en casi todos los mejores, siempre ha habido una mujer. Ya ves que, por ahora, te equivocas. Por otro lado, casi todo lo que te voy a contar lo conoces de sobra; pero aun así, calla.

»La primera mujer en la que pienso es mi madre, la desafortunada reina Juana a quien todos, plebeyos, señores y hasta papas llamaron loca y no voy a ser yo quien niegue que estaba trastornada de la sesera. Por desgracia tuvo poco trato conmigo pero en ese desquiciamiento que la asaltó desde su juventud siempre tuvo hacia mí una devoción especial y además, que nadie lo olvide, fue la auténtica reina de España hasta su muerte hace apenas tres años, de modo que yo, a quien todos habéis llamado vuestro rey desde hace cuarenta, no lo he sido en plenitud más que estos tres últimos; antes sólo he gobernado estos reinos y los del otro lado del océano con su nombre por delante del mío en cada orden y documento. Pobre madre, qué pocos días tuvo de felicidad en su existencia; los años en que permaneció soltera junto a mi abuela Isabel y los cortos meses que duró el enamoramiento de mi padre por ella. 
"Luego todo fueron sinsabores, desdenes del esposo que sólo se acercaba a ella para preñarla en el altar de la dinastía, y burlas y ninguneos por los cortesanos. ¿No había de volverse loca? Cuando yo nací mi padre ya cambiaba de lecho cada noche y no había mujer en Borgoña que no estuviese deseando ser la que se subiese a él en la madrugada, al acabar los festejos diarios. Por eso mi madre procuraba asistir a cada fiesta para celar al marido veleidoso. En una de éstas, en el palacio de un noble de Gante, llevándome en el vientre los nueve meses cumplidos que manda la naturaleza, se sintió indispuesta y creyendo que eran retortijones de tripa lo que era anuncio de otra cosa, me parió en las letrinas mientras le llegaban los sones de la música con la que mi padre danzaba con la linajuda zorrona de turno. Al cabo, tan buen sitio para nacer es ése como la mullida cama de una alcoba real. Se nace en un instante pero se vive todo lo demás y la cuna ha de valerle al hombre menos que sus hazañas. Así pienso yo.

»En Tordesillas, ¡durante cuarenta y seis años!, vivió encerrada y el marqués de Denia y sus descendientes que habrían de velar por su cuidado la maltrataron muchas veces hasta la tortura y sólo disimulaban su vesania cuando primero mi abuelo don Fernando y luego yo íbamos en persona a visitarla, lo que por desgracia pudo ser muy pocas veces. Pero aun en su locura, que no lo era sino a ratos aunque cada vez más prolongados, fue capaz de defender mis derechos frente a los comuneros que la importunaban día y noche para que firmase documentos a su favor. Al menos, los primeros diecisiete años de su encierro tuvo el consuelo de la compañía de mi hermana Catalina, la que nació después de muerto mi padre y que iba en su vientre mientras recorría enajenada los campos de Castilla tras su féretro. De esta hermanita mía, hoy reina de Portugal, te he de decir que anduvo enamoriscado aquel capitán guipuzcoano, Ignacio de Loyola, y que hasta la escribió cartas antes de cambiar la armadura por la sotana. Ya ves, Quijada, que a estos jesuitas les han gustado siempre las mujeres de mi casa, lo que no deja de ser curioso y hasta puede que quiera significar algo que no se me alcanza. Francisco de Borja asistió a mi madre en su muerte y me mandó decir que en sus últimos días parecía que había recuperado por completo el juicio perdido: si realidad o consuelo de cura, no lo sé.

El mayordomo que, en efecto, conocía todo aquello de cabo a rabo, sólo se sorprendió por lo de los amores del de Loyola hacia la infanta Catalina, uno de los pocos secretos de familia que el rey no le había contado antes. Durante el relato apenas se había movido; ahora descansó el cuerpo en el respaldo de la silla tras atizar un poco el fuego que seguía ardiendo en el hogar de la chimenea y se preparó para continuar de mudo testigo de aquel desahogo de su Señor. 
- Si mi padre picoteó en todos los nidos ajenos, aunque bien es cierto que éstos se le abrían de par en par incluso con el cornudo consentimiento de sus legítimos dueños, yo no he tenido muchas experiencias en esas batallas de amor. Y no es que lo sienta... hasta ahora, porque de las pocas, tres contadas, he sacado en cada una un placer muy diferente y que se acomodaba a la perfección con cada etapa de mi vida.

"Poco antes de cumplir los veintidós años, que es edad harto madura para iniciarse en estos menesteres, tuve, no siéndolo yo, un amor de juventud. Ella sí era casi una niña, Juana van der Gheyst, y nos amamos como sólo saben hacerlo los muchachos, a la carrera pero disfrutando cada segundo y aprendiendo cada uno de la ignorancia del otro; sin más pensamiento en todas las horas del día que el deseo de que llegara la noche y en ésta de que no se acabara nunca la acogedora oscuridad. A mí que me armó caballero un emperador y emperador un papa, me inició en esa otra orden de caballería una jovencita con la cara llena de pecas, una trenza que yo deshacía con manos torpes y ansiosas cada noche y unos pechos pequeños y redondos que me volvían loco en cada encuentro. Tuvimos una hija, Margarita de Parma, y hoy de aquellos escarceos de aprendiz conozco ya mi segunda generación. Mi nieto Alejandro Farnesio sé que es un mozalbete con visos de llegar a los más altos puestos de mis reinos; o por mejor decir, de los de mi hijo, que la memoria me suele hacer este servicio, no sé si bueno o malo, de olvidar que lo que fue mío es ya suyo. Felipe quiere mucho a su sobrino Alejandro, como llegará a querer a Juan, amigo Quijada, y lo tiene destinado a mandar algún día sus ejércitos así que las fuerzas, al crecer el cuerpo, acompañen a la voluntad que ya demuestra.

"Por cierto que, en hablando de mujeres, así como yo no tengo queja de las que han compartido conmigo su intimidad, no puede decirse lo mismo de mi hijo Felipe. Mi sobrina María Manuela de Portugal, la hija de la triste Catalina, apenas le vivió el tiempo justo de darle un hijo medio tarado; lo malo es que ese mi nieto Carlos estoy seguro de que va a proporcionar más disgustos que alegrías a Felipe y al reino. Y qué me dices, amigo Luis, de su actual esposa, María Tudor, mi prima la inglesa. La razón de Estado para esa boda fue cosa mía y aunque espero que beneficie al reino, debo confesar que en algún punto me arrepiento. La mujer es más fea que una docena de demonios, con menos gracia femenina que una berza de esa huerta de los monjes que ahora nos rodea a ti y a mí. Pero, ¡lo que son las cosas!, ella que es casi veinte años mayor que mi hijo se volvió loca de amor nada más verle desembarcar en Inglaterra y qui- 
so consumar el matrimonio allí mismo. ¡Vaya papelón para Felipe! Pero, en fin, cumplió y siguió cumpliendo con el débito hasta que María, de quien me dicen que anda en este tiempo muy mala de salud, creyó estar embarazada.

A Carlos se le escapó una carcajada que sobresaltó al mayordomo aunque bien sabía éste el motivo y la continuación de la historia. Él no se atrevió a reír abiertamente pero en su interior sintió el mismo regocijo.

- ¡Embarazada! Hasta se le hinchó la barriga y se le retiraron los meses como si aquello fuese de verdad. Pero todo terminó en viento. Allí dentro no había criatura ni para un aborto. Es tremendo y sobrecogedor lo que puede llegar a hacer la mente humana, Quijada. En fin, se frustró esa esperanza aunque lo hiciera de modo tan ridículo, y ahora anda mi hijo ocupándose de la política de nuestros reinos, ¿has visto?, ya digo nuestros reinos y no míos, en el continente y alguna vez que visita, como de cumplido, a su esposa creo que ésta quiere a toda costa llevárselo a la cama para probar otra vez aunque los médicos de allí le han dicho a las claras que no podrá tener hijos.

»Ojalá mi hijo hubiese encontrado a una mujer como su madre, mi bien amada Isabel! Isabel, Isabel, ella sola reina en mi corazón aun después de tantos años en que la muerte se la llevó de mi lado-los ojos del César se volvieron una vez más al retrato y se empañaron de lágrimas-. Sentí por ella el mayor amor que puede nacer de un hombre y recogí de su vida no otro tanto sino muchísimo más. Me amó con entrega total, con delicadeza, con paciencia por mis continuas ausencias, con respeto $\mathrm{y}$, cuando era el momento, con pasión. Me dio cinco hijos de los que dos murieron muy pronto y supo cuidarlos y educarlos a todos como madre y durante largas temporadas también como padre porque yo estaba muy lejos. Pero te juro, Quijada, que los momentos más gratos de toda mi vida, quizá con los únicos con los que me quedaría si el Creador me permitiese elegir el equipaje que me lleve al otro mundo, fueron los que paśé a su lado: Sevilla y sus Alcázares tras la boda; Granada en nuestra lủna de miel que intentamos apurar y alargar cuanto pudimos; el Alcázar de Toledo y la vega del Tajo donde solíamos reencontrarnos cuando yo volvía a España y desde donde ella supo gobernar mejor que ningún hombre mis estados; Valladolid cuando nació nuestro hijo Felipe y el mundo entero se abría ante nosotros.

El César cerró los ojos y apretó los párpados para contener el llanto que aun así se le desbordó por las arrugadas mejillas, como un arroyo de 
agua clara y fresca sobre la resecura de un erial. Quijada le contemplaba sin poder reprimir él mismo un sollozo. Conocía cada detalle porque los había oído muchas veces de labios del emperador y en alguna ocasión también adivinó algún retazo en las conversaciones, mucho menos confianzudas, desde luego, que había tenido en Toledo con la emperatriz, en esos atardeceres que sólo son dados contemplar en la ciudad del Tajo durante la otoñada. Luego siguió el monólogo.

- Hablando de Isabel se me turba el pensamiento. Su solo nombre debería impedirme continuar con esta charla; pero, en fin, te dije, Luis, que pensaba en mujeres y así lo voy a seguir haciendo en voz alta. Ella, una vez más, sabrá perdonarme que me aleje porque sabe desde el cielo que nunca se me pasó por las mientes el más mínimo deseo de engañarla. Y le fui fiel, sin esfuerzo además, todo el tiempo que duró nuestro matrimonio.

»Es lugar de que salga a la palestra de estas evocaciones la figura de Bárbara Blomberg. Había pasado un lustro de la muerte de Isabel y yo me sentía muy solo aunque nunca en soledad, siempre rodeado de gente desde el despertar hasta que el alabardero cerraba la puerta de mi cámara creyendo que yo dormiría, cuando en realidad me pasaba las más de las noches en vela, sin encontrar acomodo en ninguna postura en la cama, dando paseos por la habitación, descalzo para no sobresaltar a la guardia, o leyendo a la luz de un velón; luego me amodorraba cuando ya el amanecer se anunciaba por la ventana y por fin podía descansar unas pocas horas. Además de solo me sentía viejo a los cuarenta y cinco años, y esa mezcla de sentimientos es muy mala para un hombre, Quijada, amigo mío, que tú no la conoces. Y entonces apareció Bárbara. No era la púber Juana van der Gheyst; ni mucho menos la gran señora Isabel; era..., era... una hembra que destellaba tentaciones en la figura, en la mirada, en el moverse, en el olor de su piel blanca como la leche que procuraba acercar a mis narices a la menor ocasión.

"Nuestra relación tuvo poco o nada de amor; fue una pasión desenfrenada que duró muy corto tiempo. Pero en ese tiempo ella dio muestras sobradas de conocer todo lo que a un hombre en mi situación le hace sentirse, aunque efímeramente, cómo te diría yo...: hombre otra vez; sí, ésa es la expresión que más le cuadra. Me prodigó en el lecho placeres que yo no podía ni imaginar aunque los hubiese oído contar a algunos de mis capitanes ante el fuego de campamento la víspera de alguna batalla, cuando los hombres hablan de todo por si mañana han de morir; algo como lo que yo hago hoy aquí contigo, viejo camarada. 
»Ella lo hacía todo y yo me dejaba; cuando la fatiga de tanto jadeo me hacía desfallecer el ánimo o las armas de aquel combate, ella me daba a beber de una copa vino caliente con especias o lo derramaba desde su boca sobre mi cuerpo; luego se erguía un poco, hablaba de cualquier tema baladí, del ropaje de tal dama, de los ademanes de cual caballero en la fiesta vespertina, del calor o del frío, y poco a poco sus manos, que no descansaban nunca, lograban resucitar al guerrero languidecido y entonces vuelta a empezar. Su cuerpo, completamente desnudo, era como un mar que empieza a rizarse y acaba embravecido y yo me hundía en él como un náufrago, a la desesperada, agitando cada uno de mis miembros para salir a flote y boqueando para coger resuello. No era amor, Quijada, era furor, pero éste me cegaba y no podía ver más allá de aquellas caderas, aquellos muslos, aquellos pechos desorbitados, aquella boca entreabierta dispuesta al juego, cada vez uno nuevo y más excitante.

»Cuando al cabo de unos meses me vino otra vez la luz de la razón, quizá porque la animación del cuerpo, del mío, ya no daba más de sí, empecé a entrever que aquella mujer, si alguna vez me quiso, cosa que no creo, no era ya más que un zorrastrón. Como no hay secreto que guarden ni las sepulturas, me fueron llegando noticias cada vez menos veladas de los alardes que hacía de nuestra relación y hasta de que confiaba a sus amigas el sueño de ser emperatriz. A esto último quizá la llevó, junto con. su ambición y falta de escrúpulos, el saberse portadora en su seno de un hijo mío: ese Jerónimo tuyo y mi Juan. Nacida la criatura la aparté de mi lado, que mi cama hacía ya tiempo que no la frecuentaba, y dispuse lo mejor para ella y sobre todo para el niño. Pero de lo que pasó después sabes tú más que yo y con nada podré pagarte tu labor.

- Vuestra amistad y confianza superan cualquier pago que pudiera esperar hombre alguno, Señor. Y en cuanto a don Juan, muy pronto lo vais a tener aquí mismo. En ese sentido podéis estar tranquilo.

- Y lo estoy como siempre. Nadie mejor que tú y Magdalena para cuidar de mi hijo. Aunque cuando yo muera, que no ha de faltar mucho por los amagos que me da este cuerpo mío, habrá de cambiar su vida. Felipe ya sabe que en ese mismo momento Juan pasará a su lado y todo lo que debe hacerse con su persona y su futuro.

Esta vez fue a don Luis Quijada a quien se le nublaron los ojos.

- Yo sé muy bien cuánto lo habréis de sentir los tres; porque no sólo Magdalena y tú perderéis al que habéis tenido como hijo, sino que el mismo Jerónimo perderá a los que quiere como padres aun sabiendo que no lo son naturales, y su vida va a sufrir un cambio tan radical que espero lo sepa afrontar con bien y para bien. 
- Lo hará, Señor, lo hará. Tiene todas las cualidades para ello, doy fe- don Luis hizo ademán de incorporarse de su asiento; parecía claro que había terminado la larga remembranza del emperador sobre las mujeres que más significaron para él-. Con vuestro permiso me retiraré. Mañana mismo quiero empezar los preparativos en Cuacos para la llegada de don Juan.

Carlos alzó una mano y el mayordomo detuvo en seco su movimiento.

- Aún no es todo, quédate un poco que he de hacerte otro encargo.

Quijada obedeció, pero algo en los ojos del emperador le avisaba que lo que ahora venía no iba a ser plato de su gusto.

- Me queda poco, Luis. Los médicos y los monjes tratan de engañarme cada uno a su modo, pero yo soy más listo que ellos y además el que nota cómo día a día se me escapa la vida. Y si bien sé que me quedarían muchas cosas importantes por hacer y que no haré, hay una de menor cuantía de la que no quisiera privarme -vio el gesto de interrogación esbozado en la cara del mayordomo pero contestó sin esperar la pregunta-. Quiero que me consigas una mujer que me caliente el frío que noto en los huesos; una mujer sencilla, del pueblo, que venga por las noches a caldearme la cama y el cuerpo.

Esta vez Quijada no pudo reprimir el impulso de levantarse y miró con ojos de asombro al valetudinario rey que tenía frente a él.

- Pero, Señor, ¿una mujer aquí y ahora...?

- Considéralo una medicina, mejor, desde luego, que tanta pócima y ungüento como me recetan los médicos. Además, fuiste tú quien me enseñó ese refrán que dicen en Castilla: «El hombre pierde antes el diente que la simiente». Una mujer, sí. Sé que es difícil traerla a un palacio lleno de gente en medio de un monasterio lleno de monjes, pero arréglatelas como puedas. La disfrazas de arriero, de paje o, si hace falta, de fraile peregrino, pero me la traes. Te repito que no es necesario que te esmeres en la elección, entre otras cosas porque ya no hay mucho tiempo; pero por lo menos que no sea ni un cardo de carácter ni un sarmiento de cuerpo. Confío en ti; y ahora sí puedes retirarte.

El mayordomo siempre fiel salió de la habitación sintiendo como un vahído que le nublaba el pensamiento. No esperaba aquello, pero jamás discutió un mandato de su rey y no iba a empezar a hacerlo entonces. De modo que se encerró en su estrecha cámara y apenas se concedió unos 
minutos para poner en orden las ideas que como en un juego de pelota le rebotaban en las paredes de la sesera. Había que trazar un plan, una estrategia complejísima y, por supuesto, hallar a la mujer en cuestión, aunque ése era el punto que paradójicamente menos le preocupaba ahora.

Cuatro semanas tardó en urdir la trama y durante esos días en cada encuentro con el emperador éste no volvió a hablar del asunto pero siempre dejaba aflorar en su inquisitiva mirada un «¿Cuándo, Quijada, cuándo?» La mujer elegida fue una moza de nombre Miguela, sobrina de un colono de las tierras del conde de Oropesa; no muy alta, con el rostro marcado con unas pocas cacarañas de unas viruelas pasadas en la niñez, pero de cuerpo con redondeces suficientes para satisfacer a cualquier hombre sólo de vista, cuanto más de tacto. Al tío de la moza lo convenció Quijada con facilidad para que ésta pasase a servir en la casa que se aparejaba en Cuacos para la próxima llegada de su esposa doña Magdalena. A la chica, de carácter dulce como era el encargo, pero de menguadas luces por no tener más que las de su tío ni más mundo que las lindes de un huerto, la hizo ver que un alto señor del palacio era quien de verdad la necesitaba y que si cumplía con aquello que se le mandase, sin más detalles, obtendría muy buenos dineros y un puesto en la servidumbre palaciega. El modo de entrarla hasta el emperador sería con ropaje de mozo de cuadra que acompañase al mayordomo en sus casi diarios trayectos desde Cuacos a Yuste y viceversa.

Cuando Quijada transmitió sus planes a Carlos éste no pareció inmutarse. Llevaba unos días con fortísimos dolores, tenía el rostro macilento y apenas abría los ojos ni para hablar con los que le rodeaban.

- Déjalo estar; espera unos días a que mejore--, le dijo por fin en un aparte.

Los días de que hablaba el emperador se fueron alargando y los calores de aquel verano quizá contribuyeron a encubrir otros ardores. En ese tiempo había llegado ya don Juan a Yuste y al César sólo parecía despertarle interés el tener cerca suyo al chiquillo que hacía las veces de paje ignorante de todo. Como ignorante estaba doña Magdalena de las funciones que podía desempeñar en su casa de Cuacos aquella moza de la que su marido sólo le dijo que estaba allí para algo importante. Otro secreto más de Luis al que también accedió la esposa como doce años antes.

La noche del penúltimo día de agosto, el emperador le dijo a su mayordomo.

- Estoy mejor, Quijada; mañana trae lo que me guardas. 
A la mañana siguiente, mientras leía en el porche del palacio, al socaire del viento que ya empezaba a soplar por entre los encinares y al amor del resol que se filtraba por las ramas del gran nogal de la entrada, Carlos se sintió desfallecer, soltó el libro y se rehundió en el sillón. Lo llevaron aprisa a la cama y ya no se levantó. Murió el día 21 de septiembre apretando entre sus manos el mismo crucifijo con el que expiró Isabel, la que en realidad fue la única mujer de su vida. Dio el alma a quien se la dio / (el cual la ponga en el cielo / en su gloria), / que aunque la vida perdió, / dejónos harto consuelo / su memoria.

\section{El hombre que no quería abrir los ojos}

En medio de la rutina y la general mediocridad por las que discurrían las sesiones del congreso médico, aquella comunicación estuvo a punto de pasar desapercibida pero acabó por convertirse en la estrella del programa. Su ponente recibió numerosas preguntas en el coloquio abierto tras la exposición y muchas solicitudes para que acudiese a otros simposia de la especialidad con nuevos datos sobre aquel caso singularísimo. Muy pronto las revistas médicas se hicieron eco del mismo y en pocas semanas toda la profesión lo comentaba con uno u otro talante. Algunos galenos jóvenes se rieron, otros, más viejos, con más años y muchos enfermos vistos, lo tomaron más en serio y no faltó quien creyese recordar que en su experiencia profesional había tenido un caso algo similar si no idéntico.

Celestino Barrios García era, en efecto, un enfermo digno de figurar en los anales, tan repletos, de la medicina. Su enfermedad, que muchos no se atrevían a llamar así, era en extremo peculiar y concitó desde su publicación las más diversas teorías patogénicas e infinidad de intentos de explicación al margen de los mecanismos clásicos, canónicos, de la ciencia diagnóstica. Hasta ahora nadie ha dado en el clavo sino que cada vez se enzarzan más los partidarios de una explicación con los de otra distinta u opuesta. Mientras tanto, Celestino sigue como estaba cuando sus familiares llamaron por primera vez al doctor Suárez. Por si alguien pudiese aportar algo de luz sobre el caso, lo describo a continuación resumiendo lo que han publicado los medios científicos y lo que el mismo doctor Suárez me contó en una entrevista que pude hacerle en medio de su ajetreo y del cerco periodístico al que está sometido desde su participación en el citado congreso.

Una mañana de un día cualquiera, en apariencia igual que el anterior, Beatriz, la mujer de Celestino, se sobresaltó al comprobar que su marido, que debía haberse levantado de la cama para ir al trabajo hacía 
más de una hora, seguía allí a su lado. En otras ocasiones ya se había quedado dormido tras apagar el despertador a las siete y media y luego se despertaba de muy mal humor, corriendo y tropezando con todos los objetos del dormitorio mientras se vestía apresuradamente. Beatriz le sacudió en el hombro.

- ¡Despierta, Celestino, despierta, que son las ocho y media pasadas!

Pero su marido se zafó del meneo y con voz no de recién salido del sueño sino totalmente lúcida replicó:

- ¡Déjame, mujer! Estoy despierto hace rato.

- Pues levanta, hombre. ¿O es que hoy no vas a la oficina?

- Ni hoy ni nunca más. No pienso abrir los ojos.

Beatriz se incorporó y encendió la lámpara de la mesilla. No era muy aficionada a las bromas, pero además aquello más que chanza le parecía despropósito. Celestino reposaba la cabeza sobre los brazos cruzados y en sus labios aparecía una sonrisa que a su mujer le sonó a burlona; mantenía los párpados cerrados como si dormitara aunque bajo ellos los ojos se movieron hacia Beatriz cuando ésta siguió hablando.

- Pero bueno, ¿a qué viene esta bobada?, ¿te has vuelto tonto o qué?

- No. Es que no me da la gana abrir los ojos; estoy muy a gusto así. Ahora me levantaré si quieres, pero los ojos no los abro. No los pienso abrir de ahora en adelante, ipara lo que hay que ver!

Continuó la rara escena familiar y fue subiendo el tono de las palabras y reproches de Beatriz sin que su creciente excitación pareciese hacer mella en el semblante ni en la actitud de su marido.

Aquí es necesario intercalar un comentario para deshacer la primera impresión que lo dicho hasta ahora pudiera suscitar en el lector. Celestino había sido hasta ese mismo momento un hombre laborioso al que jamás se oyó renegar de su trabajo más de lo que pueda ser habitual en cualquier sujeto tenido socialmente por ejemplar. Desde muy joven tuvo que trabajar para sostener a su familia paterna y luego a la formada con su matrimonio. Siempre hizo las cosas bien, sin la menor queja de sus superiores sino con numerosas muestras de consideración por parte de éstos. Quiere decirse que Celestino en modo alguno era un vago que aprovechase la menor ocasión para rehuir el trabajo, incluso inventándose las ocasiones cuando no aparecieran de natural. Si aquel día había decidido no ir a la oficina el motivo tendría que ser otro que el gusto o el deseo de permanecer en casa.

Esa tarde Celestino había hecho muchas cosas: se había levantado; se arregló, incluso afeitándose sin que la cuchilla le hiciera el más pequeño rasguño, desayunó sin derramar una gota del café o una miga del bizco- 
cho; oyó la radio y a mediodía las noticias de la televisión; ayudó a Beatriz a fregar los platos después de comer; bajó al portal las bolsas de basura; y hasta, con algo de dificultad al principio, anduvo un rato manipulando en su mayor tesoro, una colección de monedas que empezó en la niñez y ahora empezaba a ser importante.

A todo esto Beatriz pasó de la primera sorpresa al enfado y luego a la burla, y más tarde al enfado otra vez y a la incredulidad y por fin al desasosiego. Cuando al acabar el día Celestino se sentó en su butaca de siempre, frente al televisor, sin haber abierto los ojos ni por un instante desde la mañana, Beatriz explotó:

- ¡Estás loco, Celestino, loco rematado! ¿Qué piensas hacer?, ¿qué piensas que hagamos?

- Mira, mujer, te confieso que hoy ha sido de prueba. Ni yo mismo creí que lo conseguiría. Pero ya está hecho. Desde hoy nos haremos cuenta de que soy ciego; como si hubiera tenido un accidente o una enfermedad de la vista.

- Ya; así, de repente-Beatriz estaba de pie frente a su marido con la tentación a punto de brotar de sacudirle un testarazo o un par de bofetadas-. Ciego de repente, pero, eso sí, ciego porque al señor le da la gana. No estás loco, jeres idiota!

- Lo que tú digas, cariño. Mañana llamas a primera hora al médico o vamos los dos a la consulta y le decimos que me he quedado ciego. A ver qué se hace en estos casos; yo no lo sé.

- Pues, seguramente, encerrarte en un manicomio o darte de palos o echarse a reír; yo tampoco lo sé.

El doctor Suárez llegó a la mañana siguiente sin que le hubiesen advertido de lo que se iba a encontrar en lo que debía de ser una visita más de un día como otro. Procurando que la sorpresa no le desencajara la serenidad debida a su oficio, escuchaba los argumentos del paciente.

- Poco a poco me he ido hartando del mundo que me rodea, y como casi todo él entra por la vista, pues he decidido cerrarle el paso. Si no abro los ojos y no veo las cosas el mundo cambia absolutamente. O sea, que me niego a ver, ¿eso es malo?

- Es raro; eso no me lo negará usted. No lo de hartarse del mundo, que eso nos ha pasado a todos, sino lo de creer que cerrando los ojos el mundo desaparece. Es algo, permítame decírselo, propio de niños, una chiquillada. La táctica del avestruz no le da resultado ni al avestruz ni al niño, ni mucho menos a una persona adulta como usted. El mundo sigue aquí aunque no queramos verlo. 
- Seguirá, sí; bueno, ya sé que sigue, pero la cosa cambia mucho cuando no se mira.

- Y ¿en qué cambia? -el médico empezaba a sentir en su interior una indefinible inquietud, quizá la de no saber muy bien qué pintaba realmente allí, porque aquél era un problema, en todo caso, de psiquiatra y no de médico de cabecera.

- Para empezar en que ya no nos pueden alterar tantas imágenes dañinas como continuamente nos asaltan desde cualquier sitio al que miremos. ¿Le parece poco? Al tener los ojos cerrados puede uno imaginarse la realidad a su gusto, estar continuamente en un mundo como de sueño; ese mundo que se nos representa cada noche cuando los cerramos en la cama y antes de que el verdadero sueño se apodere de nosotros; o como el que disfrutamos en esos momentos, tan cortos pero tan apasionantes a veces, del duermevela. Como además no soy ciego de nacimiento, tengo en la memoria todas las imágenes que existen para elegir.

- Pero es muy distinto estar dormido o a punto de dormirse o despertarse que esto que hace usted. Porque, a pesar de todo, tendrá que continuar viviendo y ese mundo que existe aunque no quiera verlo le va a exigir un comportamiento no de soñador sino real, como el de los demás.

- En todo caso, doctor, como el de los demás ciegos, lo que ya es una ventaja. Tendrán que adaptar una parte de sus actos a mi condición de invidente; y a cambio yo no lamentaré el no poder hacer muchas de las cosas que hagan los que ven porque lo mío no es una desgracia o una pérdida sino una situación voluntaria.

- Y, además, fácilmente reversible, claro. Ciego mientras le interese, y cuando deje de obtener beneficio o diversión, con abrir de nuevo los ojos asunto concluido.

- ¡Ah, no, eso no! -Celestino pareció enojarse y se puso en pie con brusquedad-. Si he decidido ser ciego he de ser, y lo seré, consecuente con mi determinación. Ciego para siempre. Así que, doctor, usted nos dirá qué se hace en un caso de ceguera; necesitaré lo papeles de incapacidad laboral, algún certificado para ingresar en la ONCE, porque yo quiero seguir trabajando pero, claro, en algo adaptado a mi ceguera. Sé que los invidentes realizan muchísimos trabajos con tan buen rendimiento o mejor que las personas normales. Nunca he sido un parásito ni pienso serlo a partir de ahora.

El doctor Suárez se levantó y se dirigió a Beatriz que había asistido al diálogo anterior con expresión de creciente angustia junto con un sen- 
timiento cada vez mayor de vergüenza, restregándose las manos sudorosas una contra otra.

- Señora: yo no puedo hacer nada más que extenderle un volante para el especialista en psiquiatría. Que él decida. Aquí tiene. Lo que sí le ruego es que me tenga al corriente. Adiós.

El psiquiatra sólo fue la primera estación de un viacrucis que empezaba para Beatriz y Celestino, aunque éste parecía no darse cuenta del sufrimiento de su esposa, y en cuanto a él mismo, se mostraba cada día más feliz y adaptado con su ceguera. Hubieron de pasar por tribunales médicos, especialistas del hospital, someterse a innumerables pruebas clínicas y psicológicas, y hasta a la inquisición de un inspector de la empresa donde trabajaba Celestino y otro de la Seguridad Social, ambos convencidos de que en aquel asunto se estaba produciendo un intento de fraude aunque no hubiese precedentes en el método.

A los tres meses Beatriz seguía penando y casi ni se atrevía a salir de casa por no cruzarse con las miradas entre burlonas y censorias de los vecinos o de cualquier conocido. El grupo de amigos prácticamente había desaparecido; en la mayoría de los casos por decisión de éstos y en otros por la de Beatriz, incapaz de mantener una conversación con nadie sin que le aflorasen las lágrimas angustiadas que había de reprimir en la convivencia con Celestino una vez que se le agotaron los lamentos, los reproches y las súplicas.

También la crisis económica comenzó a hacer presa en el matrimonio. La empresa no admitía la ceguera voluntaria de su empleado como causa de baja laboral y le abrió un expediente de despido. La ONCE tampoco contemplaba en su estructura el ingreso de un ciego voluntario y se esfumaba el deseo de Celestino de encontrar un trabajo a través suyo. Los médicos no se decidían a dar un diagnóstico y trataban el caso como un hallazgo experimental, como un conejillo de Indias en el que intentar todas las ocurrencias diagnósticas y terapéuticas que se iban sucediendo en cada consulta o sesión clínica.

Hoy las cosas han mejorado algo. Por supuesto que Celestino sigue sin querer abrir los ojos y, lo que sorprende enormemente a todos los médicos, no lo ha hecho una sola vez ni por equivocación ni siquiera por instinto. Se le ha dado un certificado de padecer una neurosis que ha sido aceptado aun a regañadientes por la Seguridad Social y cobra un dinero de incapacidad transitoria en tanto se decide su pase a la invalidez total como enfermo mental grave. Pero eso de que Celestino sea realmente un enfermo mental no lo aceptan muchos de los que le conocen y le han tratado en estos meses. Su capacidad intelectual es absolutamente normal; 
su comportamiento en nada ha variado con respecto al mantenido hasta aquella dichosa mañana salvo, claro es, en lo tocante a su empecinamiento en no abrir los ojos. Desde luego todo esto entra en el cajón de sastre que los médicos etiquetan de neurosis, pero como en tantas de éstas es muy difícil poner la raya que limite la enfermedad de la simple rareza o del comportamiento insólito.

Este es, muy resumido, el caso de Celestino Barrios García, ciego por voluntad; un hombre distinto a los demás por el que no es lícito sentir compasión, ni tampoco juzgarle con un rigor para el que carecemos de autoridad. No faltará hasta quien sienta una cierta envidia, sobre todo entre la legión de hombres y mujeres que tienen como mayor y a veces único deleite en su triste, rutinaria existencia, esos momentos en que a la noche o al amanecer permanecen con los ojos cerrados y su imaginación vuela voluntaria o inconscientemente por un mundo irreal pero más luminoso que el que alumbra el sol de cada día.

\section{Un encargo de Violante}

Te escribo, $N$., y de seguro que te extraña esta misiva si es que llega, como espero, a tus manos y no se queda atrapada en alguno de los muchos filtros que interpones entre tu persona y el resto del mundo. Te escribo, decía, porque quizá no me atreviese a decirte estas cosas cara a cara y ni siquiera por teléfono si lograra hablar contigo y no con una secretaria o cualquier quídam que te rodea y protege aun sin tú mandarlo de propósito.

Quiero hablarte de tu último encargo. Si recuerdas, me llamaste hace unos días, a una hora intempestiva, como sueles hacer, sin pedir siquiera las disculpas que al principio solicitabas aduciendo tus muchos quehaceres. Me soltaste el encargo de sopetón:

- Necesito un cuento para antes de quince días. Entre tres y seis folios. Escribe lo que quieras, pero con algún asunto emotivo. Es para el suplemento dominical del periódico $\mathbf{X}$, así que ya sabes, carga las tintas en lo social, pon alguna que otra palabrota y dos o tres términos latinoamericanos. En fin, ya sabes lo que te digo. Oye, sin falta antes de quince días. Adiós, macho, a ver cuando tengo un rato y charlamos tranquilamente.

Te confieso que tardé unos minutos en hacerme a la idea de lo que me habías pedido. ¡Un cuento! Pensé que desbarrabas, que, por la hora de tu llamada, quizá estuvieras un poco bebido y rodeado de amigos que reirían tu broma. Pero no. No podía ser así. Tus amigos, hasta los que se creen más 
íntimos, seguramente intuyen la verdad pero no se atreven a decirla y tú no vas a sincerarte con ellos ni aun con varias copas de más en tu cuerpo; siempre supiste aguantar el alcohol mejor que nadie del grupo.

Ahora que menciono a la pandilla, perdóname, me vienen a la memoria muchos recuerdos. En realidad tampoco hace tantos años como para que se olviden o para que la bruma del tiempo difumine las cosas y nos haga perder los contornos entre lo que fue y lo que nos imaginamos. Lo pasábamos bien; a ratos muy bien y otros sólo medianejo, pero según esas estadísticas que tanto manejáis los de tu oficio, el resultado es, como decís vosotros, "positivo». Me ayuda a recordar la orla de la Facultad en la que estamos todos en el último curso, hasta Pepe Ortigosa que todavía arrastraba dos parciales de tercero pero que no quiso faltar en la foto de «su curso». De la fila de cátedros sólo quedan tres en activo, los otros se han ido muriendo casi todos o están ya jubilados. ¿Será que somos viejos? No, seguramente los viejos eran ellos cuando les tocó darnos clase. Pero me estoy desviando, así que vuelvo a nuestro asunto.

Hasta ahora me habías pedido un montón de artículos de todas clases y media docena de prólogos para libros que ni habías leído ni tenías intención de hacerlo, pero cuyos autores -salvo uno, ivaya rollos, amigo mío!- estarían encantados de contar con unas letras tuyas al inicio de sus obras y en la sobrecubierta del volumen. Me acuerdo de cuando me pediste un libro sobre literatura social en el Siglo de Oro. Esto de lo «social» siempre te ha tirado mucho, sobre todo que se note y se mencione como tal, como si todo lo que se hace y se dice no fuera, sin tener que pregonarlo, tan social como lo otro. En aquella ocasión me llamaste hasta tres veces para meterme prisa.

- Oye, que me urge. Le he prometido el original al editor con tiempo para que salga a la Feria del Libro, así que no me fastidies. Con lo que a ti te gusta el tema no puede ser tan difícil. Aunque sea mándame mañana lo que tengas para ir tirando y date prisa con el resto.

Siempre con prisas. Como firmar te cuesta poco, te crees que lo que va encima de tu nombre y apellidos se hace como los churros. Pero el libro salió. Siempre ha salido todo; no creo que en ese sentido puedas quejarte de mí. Algunos artículos los hiciste -te los hice- en una noche y la verdad es que así quedaron. Una o dos veces, reconcomido de rabia, estuve tentado de hacerte esa faena que a todo «negro» se le ha pasado por la cabeza y que alguno ha hecho pasar a las antologías: mandarte un artículo copiado a la letra de algún autor célebre, con lo que se descubriría el pastel. Pero no me atreví. Pensaba que eso, al fin y al cabo a mí no me 
daría renombre y sí disgustos y tú, después del sofocón, que ése sí que no te lo quitaba nadie, seguirías tan campante y ya buscarías otro camino para realzar tu prestigio de oropel.

En la Facultad -otra vez los recuerdos- ya te alzabas sobre los méritos de los demás. Tus chistes eran de Pepe, el de la foto, el gran repetidor; tus trabajos de clase, o inspirados cuando más, o copiados de los otros o, como el de fin de carrera, pagado a tocateja al buenazo de Carlos, siempre a dos velas el hombre y pidiendo préstamos aquí y allá para ir tirando. Hasta las chicas te las habíamos «madurado» para cuando tú llegabas. Pero, a cada cual lo suyo, tenías la simpatía por arrobas, arrastrabas tras de ti a todo el curso como delegado y sabías llevarte de calle a los profesores para acomodar exámenes o prácticas o jornadas de huelga o lo que fuese menester. Luego te aprendías -porque cuando te daba la gana eras capaz de aprenderte cualquier cosa- los cuatro o cinco temas que sabíamos que le gustaban a cada cátedro y a ir tirando. Y fuera de clase, no digamos. Conocías gente de toda la Universidad y de todo Madrid; eras capaz de meterte, y de meternos si íbamos contigo, en casi cualquier sitio echándole a la cosa conocimientos o cara dura y a veces las dos cosas juntas. A ver luego quién te negaba algo cuando lo pedías echando el brazo por encima de los hombros del pardillo de turno.

Entonces no se te veía muy clara ninguna vocación, ningún proyecto profesional para después de licenciarnos. O, por lo menos, eso nos parecía, porque cuando luego te he visto encumbrado en la sociedad y en la política, he llegado a la conclusión de que ése era tu proyecto: subir; subir a donde sea si está en alto y ser perejil de cien salsas. Yo no era para ti en esa época nada especial; uno más de la pandilla; si acaso, más «empollón» que algunos pero, desde luego, menos brillante que la mayoría. No sé por qué te fijaste en mí más tarde, cuando ya cada uno andaba buscándose la vida por caminos tan dispares. Ya sé, ya sé que no soy único en tu fichero. He leído algunas cosas que has firmado y es obligado pensar que tras ellas se esconde otro "negro" o varios, que quien hace un cesto, hace ciento. Se ve a las claras que son estilos diferentes, pero quizá sea yo solo quien lo ve transparente porque estoy en el secreto, porque «soy el secreto».

Ahora me encargas un cuento. Chico, los que te rodean deben de estar verdaderamente admirados de lo variado que es tu numen literario. A lo mejor es cierto lo que un día me dijiste en una de tus llamadas y yo tomé a broma.

- Cualquier día me nombran Académico o me dan un premio gordo. Ya puedes liarte a escribir un buen Discurso de Ingreso. 
Y soltaste una risotada y yo también me reí a pesar de revolvérseme las tripas. Cuando se lo comenté a mi mujer no saliste muy bien parado. Pero eso no es novedad. No la conoces y eso te salva, porque las barbaridades que dice de ti - y ya puedes imaginarte que de mí- te las iba a soltar una detrás de otra y no son para oídas por más que yo las tenga que aguantar un día sí y el otro también.

Me pides un cuento y me pones en un serio aprieto. Yo no he escrito nunca ninguno. Me he ido a los libros y a los diccionarios a ver qué cosa sea. Las opiniones, ya sabes -bueno, no lo sabrás, claro, pero te lo digo yo-, son muchas y no aclaran nada. Porque, además, cuentos escribía Cervantes y el Canciller de Ayala, y cuentos han escritos todos los autores españoles y extranjeros del prolífico siglo XIX y cada uno lo hace de una forma diferente. Para lo que tú quieres quizá se ajusten más los cuentistas hispanoamericanos -perdón, latinoamericanos- de estos últimos años, pero aun éstos no se ponen de acuerdo.

Dicen que un cuento es un relato corto en el que debe haber, sin embargo, un asunto tratado por completo, esto es, una miniatura. $\mathrm{O}$ dicen que ha de ser una pincelada que apunte apenas un retazo de una vida o de una situación que queda difuminada, sobreentendida, a las márgenes de lo narrado. En cualquier caso, es un auténtico género literario que no se puede, que no se debe improvisar. Ya me daría yo por satisfecho con tener idea clara de un tema que tratar, de alguna vivencia que poder trasladar al papel. Pero llevo estos días estrujándome la mollera y no se me ocurre nada válido. Otra cosa es un artículo o hasta un libro que tienen su "pie forzado» y a él te agarras para tejer un entramado de frases, de períodos y hasta, de vez en cuando y sin exagerar, alguna idea original. Pero un cuento, y además con prisas, se sale de mis posibilidades. Los asuntos que se me ocurren son tan trillados que no merecen la pena ni de ponerse sobre ellos. Esto quizá a ti te trajera sin cuidado; seguramente no van a juzgar tu originalidad sino el mérito de dar a la luz una obra literaria de forma tan distinta a lo que les tienes acostumbrados. Mas a mí -respétame al menos este resto de dignidad que no saldrá nunca de mi coleto- me parecería rebajarme; -rebajarme, fijate qué cosas digo a estas alturas- el hacer un recuelo de asuntos manidos, de lugares comunes, aunque lo salpimentara, como me pides, con alguna palabrota, algún americanismo y, eso sí, mucha carga social.

Ahora me doy cuenta de que llevo escritos muchos párrafos y aún no te he dicho cuál es el motivo de esta carta. Sin duda, si has llegado hasta aquí, tú que no lees más que lo imprescindible para mantenerte a flote, tienes méritos sobrados para saber a qué viene este ya largo escrito 
de tu «ayudante» como me llamaste en una ocasión, no sé sin con sinceridad que se te escapó o con retranca. Pues bien, esto quiere ser una petición de cese en esa ayudantía. Sí, no cuentes más conmigo para mantener esa tramoya que sostiene tu prestigio. Se acabó el ser tu «negro», se acabó.

Podrías preguntarme que por qué ahora, por qué he esperado tanto para tomar esta decisión. Y no sé si te sabré contestar acertadamente. Verás, $N$.; las razones son las mismas que me hubieran debido mover a mandarte a paseo la primera vez que me buscaste. Mi situación no ha cambiado desde aquel día. Sigo, tú lo sabes, con mi trabajo de profesor en la Facultad, enseñando a otros para que a su vez enseñen... etc.; es un poco como aquella caja de galletas en cuyo paquete estaba dibujada una niña con un paquete en la mano en el que estaba una niña con un paquete en el que estaba... y así infinito. Apenas sí rompemos ocasionalmente ese círculo vicioso que puede llegar a ser agobiante, y a este dar vueltas y vueltas no sois ajenos vosotros los políticos, que os habéis olvidado de la Universidad quizá porque pasasteis por ella como sobre ascuas y sin que os "prendiera» lo que allí se pretende inocular. Pero otra vez me desvío del tema; debe de ser el subconsciente que me hace derivar para no tener que plantarme ante la realidad. Vuelvo a ella.

Aquella primera vez me tentó la oferta económica y el pensar que sería la única.

- Te necesito, chico. Me han pedido de una revista del Ministerio un artículo sobre ese tema y ya sabes que esa asignatura la aprobé por los pelos y por la cara. Hazme el favor, hombre. Total no se va a enterar nadie; con cuatro bobadas salimos del apuro, yo con una buena nota ante mis jefes y tú con unos duros en el bolsillo que nunca vienen mal.

Y tragué; tragué quina, pero lo hice. Tuviste el artículo y yo nunca lo vi porque no tenía acceso a la revista y tú tampoco me la enviaste. Fue una suerte, sobre todo para ti. Si lo hubiera visto quizá mi conciencia hubiera podido con mi interés. Lo mismo pasó, supongo, con los dos o tres siguientes artículos. Luego ya estaba metido en el tinglado y seguí tragando. La primera vez que leí uno de «tus» artículos en el periódico, a los cuatro vientos, sentí más que asco una extraña sensación de abatimiento, de rendición casi sin condiciones; hasta llegué a releerlo con cierta fruición o a lo menos con un cierto regusto de paternidad silenciosa y sacrificada. Después, ya ni eso. Eras una fuente de ingresos más, de buenas pesetas porque nunca has sido tacaño para pagarte los caprichos. 
Te mencioné antes a mi mujer y sus reproches; mis hijos aún no tienen edad suficiente para darse cuenta de las cosas, pero si continúan así también lo llegarán a hacer. Ella ha influido, no lo voy a negar, en mi decisión de hoy. Pero quiero creer, necesito creer que ha salido de mí mismo, de un rescoldo de dignidad que no hayan podido apagar tu dinero y mi dejadez. El que escribe se siente, ya te lo he dicho antes, como un padre de su obra y es muy doloroso entregar a los hijos en adopción; alguna vez la sangre ha de poder más que los otros humores de los clásicos y subirse a la cabeza y nublar razones e intereses. Encontrarás otros que hagan mi trabajo; siempre los hay y la gente como tú sabe encontrarnos porque estáis alzados no sobre vuestros méritos sino sobre las miserias humanas de los demás y si éstas desaparecieran desaparecerían también los de tu calaña. Pero no caerá esa breva.

Al cabo, nada te debo. Como dijo Machado, «debéisme cuanto he escrito". A lo mejor, a partir de ahora me dedico a escribir para mí mismo y hasta consigo verlo publicado. Será difícil que se me ocurran cosas sin ser de encargo, pero, al fin, oficio no ha de faltarme; casi puẹdo escribir de cualquier cosa y en cualquier formato.

Lo que no veo factible es escribir un cuento. Ese ha podido ser el detonante de toda esta historia. Me mandas hacer un cuento y estoy, después de mucho rasguear con la pluma, terminando de escribirte una carta cuanto amarga liberadora. Yo no sé escribir palabrotas, no me salen; yo no sé escribir americanismos a pesar de haberlos leído en Borges y en Cortázar y en García Márquez y en tantos otros y de haberlos repasado en las últimas jornadas por tu interés en ellos. Pero acabo de releer lo que llevo escrito, con una fugaz tentación de romperlo, y me doy cuenta de que si no hay palabras malsonantes o exóticas, no cabe duda de que sí hay suficiente de esa «carga social» que tanto te interesaba. Así pues, me despido de ti usando otra vez palabras prestadas de un poeta que quizá se viera en alguna situación semejante a la mía de hoy:

"Contad si son catorce, y está hecho».

\section{El día de Gracia}

En el cielo -esto lo sabe muy poca gente- existe una tertulia literaria que se reúne todas las tardes si es que tiene tardes la eternidad. La preside Homero, elegido sin discusión primero entre los iguales por haber sido ya divino mientras vivió. Asisten a ella, según les dé: César, lacónico y un poco impertinente; el Arcipreste Juan Ruiz, jocoso; Cervantes, ta- 
citurno por lo general; Shakespeare, siempre polemista y agrio; Molière, burlón y malintencionado; Balzac, charlatán incansable; Tagore y Kipling, espiritados y haciendo corrillo aparte para hablar de las cosas de su India; Juan Ramón, hipocondríaco y huidizo; Juan de la Cruz, siempre absorto; y otros muchos escritores de todos los tiempos aunque con claro predominio de los que fueron en vida españoles, quizá porque aquí la tertulia ha tenido mayor raigambre y eso se traslada también a la otra orilla.

En esta asamblea se habla -está de más decirlo- de todo lo divino y lo humano. Los asuntos brotan de continuo y espontáneos y cada cual aporta su versión y su criterio sin que por lo común se pongan de acuerdo los tertulianos; pesa mucho la gloria de la inmortalidad a la hora de aceptar la razón ajena o de ceder un punto siquiera en el mantenimiento de la propia. Pero si en este encastillarse cada cual en sus razones reside buena parte de la gracia de las tertulias humanas, no puede esperarse que la cosa sea distinta allá arriba. Las tertulias no se han hecho para que sus miembros de diario se convenzan mutuamente sino para dar acompañamiento a los monólogos sucesivos o simultáneos y para que aprendan los mirones lo que es sabiduría y gracia y agudeza de ingenio.

José Zorrilla es cofrade tenido por fijo aunque menudean sus ausencias cuando se va de charla con hidalgos castellanos o a recitarle endecasílabos a alguna princesa morisca que vea pasar como alma en pena temblorosa de amores desgraciados. A Zorrilla los otros de la reunión no suelen tomarle muy en serio y hacen frecuentes chanzas de sus arrebatos románticos. Si acaso, Cervantes le mira con ojos de comprensión y hace gestos de compartir muchos de aquellos ensueños, pero Don Miguel habla poco y Zorrilla se queda solo añorando lances caballerescos de final siempre dramático.

Seguramente fue el coñón de Juan Ruiz o, quizá, Mariano José de Larra que respira siempre por la herida, quien sacó aquella tarde el asunto a colación. Por unos instantes todos callaron para oír sus argumentos que exponía sin quitar la vista del poeta del Tenorio.

- Ahí abajo ya no queda ninguna Doña Inés, virgen y pura, capaz de sufrir un embeleso por cuatro palabras bien dichas y dispuesta a ofrecer su alma por la salvación del sinvergüenza que se las dijo. Yo afirmo que no la hubo nunca; que las mujeres han sido antes como ahora unos seres movidos por el interés: de poseer riquezas, de ser admiradas y servidas por los hombres y por las otras mujeres o, sencillamente, de dominar a quienes tienen más cerca, que suelen ser los novios primero y los maridos o los amantes después. Aque- 
lla novicia que se inventó nuestro amigo Zorrilla no es más que eso, un puro invento que careció siempre de la más mínima realidad. Y desafío a quien me lleve la contraria para que señale un solo caso, en este mismo instante, de una jovencita que atesore esa pureza que imaginó el ingenuo José.

- Yo mismo lo haré -saltó Zorrilla, blanco ahora de las miradas de todos los asistentes-; voy a pedir al Señor el Día de Gracia y os indicaré no una sino hasta una docena en cuanto baje.

- Con una basta- dijo el otro.

El Día de Gracia es un efímero retorno del más allá que la Misericordia Divina concede una sola vez en la eternidad a quienes dejaron alguna cuenta pendiente. A estos Días corresponden muchos hechos extraordinarios que los mortales no sabemos explicar pero en los que tenemos la intuición de que algo o alguien ha venido para torcer con un soplo la llama de nuestra existencia; unas veces a nuestro gusto, otras, de acuerdo a una escondida voluntad cuyo origen se nos escapa.

La juventud se rige por horarios particulares que poco o nada tienen que ver con los del resto de la sociedad de la que forman parte biológica. Cuando la mayoría de los humanos se recoge en sus hogares después de una jornada laboral o de ocio es el momento elegido por los jóvenes para salir de esos mismos hogares camino de sus centros de reunión. Incluso el atardecer o la anochecida son pronto para ellos; buscan para sus actividades la noche cerrada; pero no porque gusten de la oscuridad celestinesca, ya que sus lugares de diversión disponen de abundante iluminación artificial. Son como las polillas y mariposas nocturnas, que rehuyen al sol, brillante y vivificador, y revolotean alrededor de una farola o del pábilo oscilante de una vela, remedos artificiales de la luz del día a la que jamás conseguirán aproximarse. '

Era una tarde primaveral de Madrid, de esa primavera madrileña algo tardía que empieza a caldear los cuerpos después de muchos meses de estar ateridos, y, sobre todo, despierta los espíritus con un suave cosquilleo a través de los sentidos: el aroma de las primeras flores en parterres y jardineras; los colores de un cielo increíblemente transparente y de las arboledas que renacen del invierno; el piar incansable a todas horas de los pájaros que se buscan en las enramadas; el contacto sobre la piel de un aire tenuemente caldeado, como una caricia.

Zorrilla callejeaba sin que las muchas novedades ciudadanas le sorprendieran demasiado a pesar de la colosal diferencia entre esta ciudad y la que él paseó durante sus años de vida. Quienes vuelven en su Día de Gracia apenas tienen sensibilidad para los objetos inanimados; su misión 
se dirige hacia los hombres y es a éstos a los que prestan atención, a sus conductas y a sus íntimos pensamientos que para ellos son tan visibles como para nosotros los gestos de la cara.

En esas horas vespertinas muy pocos jóvenes andaban por las calles. Abundaban, por contra, las personas ajetreadas en vehículos y a pie, yendo en mil direcciones, sin mirarse unos a otros si no era porque tropezasen o se interrumpieran el paso entre sí. Y aun entonces sólo se dirigían un vistazo malhumorado con un gesto de desdén hacia el prójimo que parecía existir nada más que para estorbarle a uno. En esto sí notaba un cambio sustancial con su tiempo, cuando todos se conocían o hacían por conocerse; cuando el saludo y la cortesía eran todo un rito aprendido en la niñez y fomentado en la edad adulta aunque no pocas veces se tiñera de hipocresía o de amaneramiento.

Al cerrarse la noche miró Zorrilla hacia lo alto buscando entre las estrellas el lugar desde donde sus contertulios estarían observándole. Pero no vio ninguna estrella. El cielo de la ciudad tenía un color lechoso o como de panza de burro allí donde unas horas antes se extendía el azul cambiante del último resol. ¡Qué cosa más rara!, se dijo el poeta, ¿no tendrá nunca esta gente la necesidad o el gusto de mirar el cielo estrellado? Desde el otro lado sí se ven los luceros y se pasea entre ellos y sirven de punto de cita para los que ya han cruzado la frontera.

Poco a poco se vio rodeado por la juventud que buscaba. Al traspasar un rectángulo de luz irisada que se filtraba por los cristales de un local, del que también salía una música de ritmo machacón, casi se dio de bruces con una pareja que, apoyada en un automóvil se abrazaba y besaba con un ardor que sería de esperar en la penumbra de una alcoba mejor que al aire libre y frente a cualquier espectador. No; aquélla no podía ser una Doña Inés que contiene su impulso amoroso en la escena del sofá.

Pocos metros más allá se detuvo a contemplar otro espectáculo. Esta vez era un grupo de chicos y chicas, apenas en los límites de la adolescencia, quienes ocupaban su tiempo en jugueteos amorosos durante los que no se recataban de entregar su intimidad al manoseo del vecino que, a cambio, ofrecía la suya con la misma ligereza. Unos vasos, presumiblemente de alguna bebida alcohólica, pasaban de mano en mano y de boca en boca, lo mismo que unos cigarros malolientes que apuraban hasta quemarse los labios. El lenguaje que utilizaban para comunicarse no solamente no era el de las endechas y madrigales sino que estaba limitado a muy pocos vocablos que además parecían necesitar la ayuda continua de muletillas para salir de las gargantas.

La siguiente pareja, que caminaba unos pasos adelante, parecía más normal; él y ella, cogidos de la mano, con las cabezas muy juntas, man- 
tenían una actitud de enamorados que se arrullan. Zorrilla apresuró el paso para verlos de frente, seguro de que en la cara de aquella muchacha iba a encontrar los rasgos de primor que imaginara para su Doña Inés. $\mathrm{Ni}$ siquiera lo imperturbable de su condición de espíritu fue suficiente para evitarle la sacudida. Aquella pareja lo era sólo por ser dos, como los animales de una yunta; la previsible muchachita era un tipo rubiasco, con una buena mano de maquillaje por la cara que no bastaba a cubrir sus rasgos de hombre; el otro mantenía algo más la imagen varonil a cuenta de un bigote tupido y la aparente ausencia de afeites en el rostro. La sola idea de los arrullos amorosos que un momento antes estimuló al poeta se le convirtió de pronto en un pensamiento repugnante.

Bien sabía él que más de uno de sus contertulios cojeaba del mismo pie que aquellos dos sujetos y que en el gremio de los poetas y literatos hay quien además de en la mano lleva la pluma como adorno de solapa. Pero guardaron las formas y el que no lo supo hacer recibió el rechazo de sus coetáneos y la sorna de sus lectores. En cambio, esa pareja de ninfo y cacorro no parecían llamar la atención de nadie sino la de él que venía de otro mundo. Zorrilla había llegado a estar casi de acuerdo con uno de sus frecuentes compañeros de charla, Gregorio Marañón, sobre la inmadura virilidad de su Don Juan; pero ni el sabio médico ni nadie en sus cabales hubiese imaginado al burlador sevillano en el lugar de uno de aquellos muñecos.

Avanzaba la noche y con ella su Día de Gracia sin que viera culminada la misión que le había hecho solicitar, y agotar, aquel privilegio. Ya no miraba al cielo, borrado por las luces de los hombres, pero adivinaba sobre sí los ojillos burlones del Arcipreste y creía escuchar sus infantiles palmoteos de alegría al sentirse vencedor en el envite que se jugaba entre ambos. El límite sería la primera claridad que, como en el Ramadán, permitiese distinguir un hilo blanco de otro negro. Curioso límite, se dijo, cuando aquí se niegan las tinieblas con un millón de lámparas que parecen esperar desafiantes la amanecida. Sin embargo, allá arriba esos detalles se cuidan mucho y quizá le sorprendiese el primer rayo de sol sin darse cuenta. Era necesario apresurarse.

La ciudad, tan grande, tan exagerada, se va deshilachando por los arrabales y se acaba perdiendo en el campo con salpicaduras aquí y allá de casuchas que esperan verse algún día engullidas por otro ensanche. Estas tierras de nadie son, como lo fue siempre el alfoz de cada ciudad, el escenario de una vida marginal que ignora las leyes y a la que éstas parecen también dejar de lado. En uno de esos lugares, mitad por mitad sembradío y escombrera, dos figuras llamaron la atención de nuestro espíritu itinerante. Una era un cuerpo tendido sobre unos terrones hú- 
medos aún de las últimas lluvias; un jovencillo de edad no muy diferente a los que poco antes viera bebiendo y manoseándose; parecía yerto o quizá ya sin vida; su brazo izquierdo, arremangado, mostraba un riachuelo de sangre que había brotado del punto en el que todavía estaba clavada la aguja de una jeringuilla. La otra figura se arrodillaba junto a la primera y sollozaba sin aspavientos; era una muchachita morena, desgreñada, con el rostro sucio surcado por dos regueros de lágrimas que emborronaban más aún aquella cara que seguramente era bonita y suave. La chiquilla sujetaba entre las suyas una mano de su compañero y se la acercaba al pecho y a los labios.

- ¡No me dejes! ¡Yo te quiero, llévame contigo! ¡Todo te lo perdono, pero llévame contigo!

Alzó la mujer los ojos al cielo en actitud suplicante. Y Zorrilla siguió aquella mirada. Entonces se dio cuenta de que allí si había estrellas, todas las estrellas asistiendo como mudos testigos al drama humano. Y de que por la raya del horizonte una línea de plata anunciaba el final de la noche y de su tiempo.

- ¡Arcipreste -gritó a lo alto-, ésta es Inés; te he vencido!

\section{Marcelino el halcón}

A Marcelino Suárez Figueredo le llaman en la aldea el halcón. Si alguien preguntase, que no lo hará, el porqué de este mal nombre, le dirían que por tener la cara de ese pájaro, los ojos muy abiertos y bullidores $\mathrm{y}$, sobre todo, por tenerlos siempre mirando lejos, como viendo algo que los demás no alcanzan. Marcelino el halcón tiene ya más de sesenta años cumplidos que se le marcan en las facciones porque han sido años de trabajo recio en el terruño, para arrancarle poco más que la subsistencia cotidiana y algo que bajar al mercado los primeros y terceros jueves de cada mes. A decir verdad, lo único que conserva fresco Marcelino es el brillo de esa mirada que le valió el apodo.

¿Qué mira Marcelino el halcón? ¿A dónde va su mirada? Nadie podría decirlo sin temor a errar; sólo él nos lo diría si quisiera. Y ¿dónde le encontraremos para preguntárselo? Marcelino el halcón pasa el día entre el sembrado y las rúas de la aldea; alguna tarde se le ve por la taberna de la plaza, haciendo de cuarto en una partida de brisca o de chamelo, con un cigarrillo en los labios y una copa de aguardiente a la vera, o sentado junto a la mesa en que otros juegan y hablan. Pero el lugar preferido de Marcelino el halcón, en el que pasa sus mejores ratos y donde siempre se 
le encuentra desde media tarde hasta la caída del sol, es el banco de piedra carcomida y musgosa del viejo apeadero del ferrocarril. Allí Marcelino es más halcón que en ningún otro sitio. Allí sus ojos otean el punto en que los raíles se pierden tras el recoveco de un cerrillo y así permanece, sin casi pestañear, las horas que dure la luz del día. Cuando al crepúsculo ya no se distinguen las vías del campo que las bordea, Marcelino el halcón aún echa otro pitillo sin apartar la vista del ya invisible sendero de hierro; luego se levanta y a paso lento, ¿qué prisa tiene?, se va hacia el caserío, saluda a unos y a otros, capacea con alguno que ahora sale de la taberna y se entra en su casa donde su hermana Rosa tendrá ya puesta la mesa y el condumio con que acabar la jornada.

Sólo una vez en su vida, cuando entró en quintas, salió Marcelino de la aldea. Él y otros dos mozos subieron en el apeadero al tren que paraba un instante en su camino del pueblo minero, más arriba del suyo, a la ciudad industrial del valle. A los dos días estaba, él solo, de vuelta. El tribunal médico le había dado por inútil para el Servicio por estrecho de caja. En total viajó en aquel tren apenas seis horas entre la ida y el regreso. Un vagón mixto de carbonera, almacén de herramientas y unos bancos corridos de tablas para una docena de pasajeros fue toda la comodidad que pudo tener. Pero aquel viaje marcó indeleblemente su vida para en adelante. En las tres horas de recorrido, asomado a la ventana y medio cegado por la carbonilla, contempló un mundo del que nadie le hablara nunca. La ciudad, pequeña ciudad de antañona catedral, seis palacios blasonados, unos centenares de tiendas y otros cientos de bares, fue para Marcelino un descubrimiento no menor que lo sería Méjico para Cortés y sus soldados. Aquellas escasas cuarenta y ocho horas, descontado el tiempo de fonda y cuartel, las disfrutó hasta exprimir cada minuto como el borracho pueda hacerlo con la indeformable botella que contiene su néctar de vida.

$\mathrm{Al}$ volver a la aldea y reintegrarse a las labores que siempre hizo y siempre haría, comenzaron por las tardes sus paseos hasta el apeadero. Sentado en el banco, ajeno al por otro lado escaso ajetreo del lugar, pasaba las horas fijo en el perderse de las vías. El guardagujas intentó al principio entablar alguna charla con el visitante, pero éste parecía no escucharle por lo que pronto desistió y se limitaba a mirarle al llegar y al marcharse. ¿Qué hace Marcelino en esa actitud? Sueña. Marcelino imagina y sueña viajes y para enderezar sus pensamientos toma como ringleros los raíles del tren. Cada persona usa una referencia para dar vuelo a su imaginación si es que la deja marchar. Marcelino usa la vía del ferrocarril y sobre sus bruñidas rayas desliza su mundo interno hasta los confines del otro mundo, el exterior. 
Mas la fertilidad de una imaginación, como la de la tierra, sólo se manifiesta si sobre ella cae una semilla y llueve y luce el sol. La semilla, el agua y el sol eran para Marcelino el halcón los relatos que escuchaba de quienes, habiendo salido de la aldea, volvían y se explayaban en conversaciones sobre lo visto y vivido.

Primero fueron sus compañeros de quinta; por ellos conoció Marcelino la existencia de lugares más lejanos aún que la ciudad que él correteó de pasada en su frustrada incorporación al Servicio. Supo de otras plazas, otras calles y otras gentes. Y lo que les oía contar alrededor de la mesa tabernaria o al solecillo caliente de la salida de misa, sentados junto a la olma, él lo guardaba para sí y después, cuando el día se acaba, se iba a rumiarlo en su banco del apeadero y adornaba de su propia cosecha lo relatado por los mozos y se veía a sí mismo en los pasos que ellos dieron.

Más tarde fueron unos vecinos que habían llegado hasta la capital de la provincia. La imaginación calenturienta de Marcelino el halcón le presentaba ante los ojos, allá donde los raíles se juntan, inmensas luminarias, coches, tranvías, tiendas, edificios colosales, hermosas mujeres, hombres trajeados y encorbatados. Esta ciudad le dio de sí para muchos meses, cada día con variantes en uno u otro detalle que él pensaba haber oído pero que quizá fuesen inventados por su desbocado cerebro.

Cuando Jesús, el alcalde, volvió de Madrid tras una imperiosa gestión en el Ministerio de no sé qué, Marcelino no faltaba ninguna tarde a la taberna donde Jesús jugaba su partida para extasiarse con sus palabras que atesoraba en la memoria para hacer su «viaje» vespertino. Otros del pueblo envidiaban al alcalde por haber hecho esa escapada. Marcelino el halcón no. El sabía que cuanto aquél contase lo podía revivir en sí mismo y aun acrecentarlo con sólo mirar su querida vía del tren.

Un día vino a la aldea un nuevo cura a sustituir a Don Fermín que había muerto entre olores de santidad y miseria. El recién llegado era joven, aproximadamente de la misma edad que Marcelino por entonces. Se llamaba Don Crescencio y no hacía mucho que había cantado su primera misa. Pronto se integró en la vida sin excesivos recodos buenos o malos del pueblo. Si acaso, ruaba menos que sus predecesores y gustaba más de pasar las tardes en la rectoral dedicado a su afición favorita que no le parecía muy digna de divulgarse entre los parroquianos: era infatigable lector de libros de aventuras y en especial de las obras de Julio Verne. Trajo consigo una buena provisión de volúmenes de cubiertas y bordes sobados por el frecuente uso; a más de éstos, estaba suscrito a una editorial que le remitía periódicamente, envueltas en un discreto papel marrón, las últimas publicaciones del tema. 
El caso es que Marcelino, que no era demasiado curioso, hubo de ir cierto día a la casa rectoral y sorprendió a Don Crescencio en abstraída lectura, y al dejar éste sobre la mesa, un poco azorado por la visita, el libro con que se ocupaba, los ojos vivaces del halcón cayeron sobre la cubierta en que destacaba en colorines un ferrocarril atravesando una llanura. No pasó desapercibida para el sacerdote la brusca fijación de la mirada e interrogó a Marcelino sobre ese interés.

A partir de ese día se entabló entre ambos hombres una amistad fortalecida por un tácito acuerdo de secreto sobre sus comunes aficiones. El cura comenzó a prestar algunos libros a Marcelino que los leía en su cuartucho con harto esfuerzo pues nunca tuvo más letras que las imprescindibles para no ser incluido en el censo anual de analfabetismo que redactaba el secretario del ayuntamiento para enviarlo al Gobierno Civil. Con esto se le iban las noches en vela, cerrada la puerta del dormitorio para que Rosa no se enterase de lo que hacía. Y las tardes en el apeadero se convirtieron en una inacabable serie de viajes no ya a la capital o a Madrid, sino al mundo entero, con el recuerdo de lo leído y siempre con el único apoyo material de los raíles por los que habría de iniciarse cualquier salida.

Recorría ensimismado el Africa y América, Asia y toda Europa aunque nunca hubiese visto en un mapa el escenario de sus sueños. ¡Qué más da! Si se mezclan en un trayecto indios y negros y caballeros británicos y cosacos rubios, no importa, porque nadie pone fronteras geográficas o raciales en un viaje que se hace dentro del propio alma. Cuando Jesús, el alcalde, traía al recuerdo de la tertulia algún episodio de su estancia madrileña, Marcelino el halcón se sonreía y, aunque callaba, adquiría un cierto aire de superioridad mientras pensaba para su coleto: «sí, sí, mucho Madrid, pero no se puede comparar con Londres y París, y no digamos con Bombay sin ir más lejos».

Las posibles variantes eran, claro está, prácticamente infinitas, que nunca se agotaba el reservorio de Don Crescencio. Julio Verne, Salgari, Mark Twain y tantos aseguraban a Marcelino el halcón un repertorio inacabable de viajes, placenteros unos, transidos de aventuras otros; éstos de corto recorrido, aquéllos transoceánicos; todos, al cabo, apasionantes y deleitosos. Empezaban en el andén del apeadero y finalizaban cuando el sueño podía más que el ardor de la imaginación y cerraba los sentidos al halcón para recomenzarse al día siguiente.

Ahora, en algún lugar de la Administración donde seguramente saben más de esto, han decidido que el tendido ferroviario que une la ciudad industrial del valle con el pueblo minero de la montaña ya no es necesario o no es rentable o lo que sea, y van a suprimirlo. Pero no 
conformes con dejar en el olvido este viejo ramal y que las hierbas y las aguas lo desmoronen y lo entierren, han tomado la determinación de desmantelarlo por completo y ya han comenzado a arrancar los raíles y a hacer hogueras con las traviesas que los sustentaban. Al apeadero de la aldea le ha tocado también el turno en el desguace. Grandes camiones y otras máquinas han venido estos días para hacer el trabajo que no durará más allá de dos o tres jornadas.

Desde que el rumor empezó a correr por el pueblo, Marcelino el halcón estaba extraño aunque nadie le llegó a preguntar la causa. No se le veía más que muy esporádicamente por la taberna, parecía huidizo con los que se cruzaban con él en el camino de la huerta y a las veces ni respondía al saludo que se le dirigía. Semejaba haber envejecido y hasta aquellos ojos brillantes tan característicos parecerían a quien se fijase en ellos más apagados. A los pocos días incluso dejó de ir por la casa cural para su casi clandestino préstamo de libros. En la soledad de su cuarto no leía sino que se limitaba a mirar los libros y a acariciar sus lomos y el corte de las hojas en movimiento repetitivo y diríase que alelado. Lo que no dejó de hacer fue subir al apeadero cada tarde y allí siempre seguir mirando el mismo punto; en esos ratos volvía a sus ojos el brillo de antes y casi nadie podría decir que algo estaba pasando en la intimidad de el halcón. Alguien, quizá, sí pudiese.

Don Crescencio echó en falta a su asiduo visitante y un poco confidente y, al cabo de los días, decidió resolver su extrañeza. Se dirigió un atardecer al sitio donde estaba seguro de encontrarle. Allí estaba, sentado en su eterna postura, dando maquinales chupadas al pitillo. No vio al cura hasta que éste le tocó el hombro sobresaltándole. El viejo y destartalado apeadero estaba ahora solitario; hasta un rato antes habían estado los obreros desmontando las vías y cargándolas en un camión.

El cura, conocedor por oficio de lo que los semblantes humanos significan, percibió enseguida que eran tristeza y amargura las que atenazaban a su feligrés y amigo; pero no se le alcanzaba el por qué pudiera hallarse bajo esa pesadumbre.

- ¿Qué te pasa Marcelino? ¿Qué tienes, hijo, que así te preocupa?

La respuesta de el halcón sorprendió al sacerdote, a pesar de que en toda la aldea, en todo el mundo, sólo él podría comprenderla.

- ¡Ay, señor cura! -dijo, a la vez que desviaba los ojos una vez más hacia las vías ya casi desaparecidas- ¿Y a dónde voy a viajar yo ahora? 


\section{El pescador y la princesa}

Celestino Bazán es pescador de bajura, ni siquiera patrón del barco en que faena, y apenas tiene cuatro cuartos. Pero Celestino Bazán es un hombre afortunado porque anda en amores con la princesa de un castillo de arena. Su amor es limpio y puro y ya va para tres años que se iniciaron las relaciones. A Celestino Bazán no lo creyó nadie cuando contó sus primeros encuentros, sus iniciales requiebros correspondidos y los comienzos de su romance. Hoy ya no habla de ello con los otros hombres; sólo se sincera con la espuma de las olas y con los peces que brillan con la luz de la luna entre las redes del aparejo.

A Celestino, hombre de la mar, no le gusta perderla de vista. Por eso solía pasear por la playa que se extiende desde donde se apoya el largo brazo del malecón hasta el infinito. El rumor del oleaje acompasaba su andar y de trecho en trecho se detenía a mirar al horizonte o pasaba un rato garabateando con una concha monigotes en la orilla húmeda de la bajamar y apostando consigo mismo a si alguna ola más tendida que las otras alcanzaría a borrar el dibujo.

Una tarde, cuando el sol cae del otro lado de la montaña y el mar toma un color de acero, como si el piélago quisiera cubrirse de una armadura para no sé qué combates nocturnos con algún gigante de los sueños, Celestino tropezó con un castillo de arena y del traspié cayó de bruces. Soltó entre dientes un juramento y escupió un salivazo embarrado. Luego oyó muy cerca de él lo que le parecía una risa de mujer. Sin levantarse, se volvió hacia el montón de arena que le había zancadilleado.

Era un castillo de los que hacen los niños durante sus juegos en la playa. Con su foso, su puente, sus torres y sus almenas y hásta con un gallardete de plástico anaranjado sujeto por una pajuela en lo más alto de una de las torres. La imaginación del niño había labrado con las uñas unas ventanas en uno de los lienzos de la muralla. En uno de tales huecos, nada más que esbozado en la pared arenosa, vio la figura completa de una mujer vestida con unos ropajes como jamás hubiese contemplado. Un manto de raso verde, una capa de seda roja, unos chapines de ante y un tocado alto y de punta con un velo de blanca gasa que la brisa flameaba. $\mathrm{Y}$ en medio de aquellas telas un rostro como de ángel, sonrosado y perfecto, alegrado por una risa que aún lo embellecía más.

- ¡Qué gracioso, qué gracioso! ¡Ja, ja!

Celestino sacudió la cabeza varias veces, pestañeó otras tantas y hasta se pellizcó en la cara por ver si estaba consciente o el golpe le había atolondrado. Al fin, se atrevió a preguntar. 
- ¿Quién demonios eres tú?

- Ningún demonio -respondió ella con una voz algo metálica, como de caja de música-. Soy la princesa Marlinda, hija del rey Océano. Vivo aquí mientras mi padre rige el curso de los mares. Si quieres, puedes pasar. Mi dueña duerme hace rato y se me pasan las horas aburridas: no sé bordar aunque me enseñaron de niña, leo poco y sueño mucho. Un rato de conversación quizá me alivie del tedio de tantas jornadas mirando cómo sube y cómo baja ese mar y de dirigir mis monólogos a los peces y a las conchas que no me entienden o parecen no hacerme caso.

Entró Celestino cruzando el puente y enseguida llegó a un salón de estilo gótico, con alto techo de fina crucería y grandes ventanales ojivados por los que penetraba el sol poniente rompiéndose en los mil colores de las vidrieras. En uno de los extremos, sentada sobre el poyo de piedra de una ventana salediza, estaba la princesa; lo vio entrar e hizo un gesto de sorpresa que era más de coquetería; lo llamó a su lado.

Iniciaron una charla como se hace siempre, hablando del tiempo, pero muy pronto se hallaron hablando de sí mismos. Por cortesía, fue Celestino el primero en contar su vida, que tampoco llenaba una crónica. A los rasgos vulgares, lineales, que iba trazando el pescador, asistía la princesa con muestras de alborozo, como si lo que oyera fuese la mismísima historia de Lanzarote del Lago o los triunfos de Carlomagno y sus doce Pares. Los mínimos detalles de una jornada de pesca, con su mar rizada y mareadora, las redes llenas de peces y el trabajo de subirlos a bordo; las chanzas entre marineros, el mal genio del patrón, el cansancio de la madrugada; todo, todo le parecía fascinante y suspiraba con cada uno o dejaba escapar un pequeño gemido de tensión. Y este recibimiento que la princesa hacía de sus pobres cosas sirvió para que Celestino mismo se las creyera importantes, y así que iba hablando encampanaba la voz y manoteaba en el aire para dar mayor realce a cada punto del relato.

Marlinda le contó, seguido, que aquella morada era sólo provisional porque cada noche la pleamar arrasaba su castillo y tenía que mudarse a otro cualquiera que encontrase por la orilla, recién construido y a veces hasta sin terminar porque la constancia no es virtud que posean los niños. Pero siempre encontraba alguno y nunca le faltó un techo que la cobijara de los rayos del sol. También le dijo que su estancia en las playas era por temporadas, durante las estaciones de calor, cuando los hombres y, sobre todo, los niños bajan hasta allí y rescatan su vocación constructora, esa vocación que yace en el fondo de los hombres desde la más remota antigüedad y que los tiempos han disimulado. Durante el invier- 
no Marlinda vivía con su padre porque éste, viejo ya, soportaba mal la soledad en los meses fríos y la mandaba llamar por medio de un hipocampo muy brioso de sus cuadras submarinas. Allá en el palacio abisal Marlinda cocinaba para el rey y para los íntimos de la corte, siendo muy celebrados sus potajes, tan reconfortantes en el mal tiempo y, sobre todo, sus postres de sartén, en especial las torrijas y la leche frita.

Celestino quiso saber, ya entrados en confianza, si la princesa no tenía novio o, al menos, pretendientes de su clase.

Dijo ella que no, que alguno hubo que se acercó a esa condición: el hijo de un duque que gobernaba en nombre de Océano los lejanos mares de China. Pero que a ella no le gustaba ni poco ni mucho.

- Tiene los ojos chiquitos y rasgados, es amarillento de piel y le huele el aliento a bacalao porque en su ducado es costumbre masticar sus raspas como si fuese tabaco de hebra, pues dicen que ayuda a conservar la dentadura blanca y lustrosa.

- ¿El bacalao? -preguntó interesado el pescador.

- Sí. Han probado con dorada y con lubina, que dan mejor aliento, pero el bacalao se ha mostrado mucho más eficaz.

- ¡Caray!

A partir de aquel día se sucedieron las visitas de Celestino a la princesa. Algunas veces la tenía que buscar en los distintos castillos que aún se mantenían enhiestos, pero otras era ella quien le silbaba desde alguna almena o sentada en el puente con los pies chapoteando en el agua del foso. De la amistad del primer encuentro pasaron en pocas fechas al amor mutuamente correspondido. No fue necesaria una declaración formal; los dos supieron lo que sentían y se cogieron de la mano mientras hablaban de cualquier cosa que a ambos les divertía.

Una sola duda cruzó por la mente de Celestino y se apresuró a plantearla.

- ¿Qué dirá tu padre de los nuestro?

- No dirá nada -contestó la princesa-. Seguramente no le hará mucha gracia porque es muy suyo y tiene para mí el proyecto de que me case con un príncipe, quizá el hijo del rey de los vientos que es muy amigo suyo, o un sobrino del rey de las tormentas, aunque éste le gusta menos porque dice que habla muy alto y que arrastra los pies, dos detalles que, según mi padre, desdicen del señorío de los príncipes. Habrá que darle tiempo; al final aceptará lo que yo le diga y terminaréis por haceros buenos amigos.

Pasaban las jornadas como un suspiro. Una tarde en que la marea alta había sido muy temprana no quedaron castillos en la orilla. Tuvie- 
ron que verse en una humilde atalaya hecha con un simple cubo vaciado al desgaire. Pero para compensar, ese mismo día encontraron sobre la arena la figura de un delfín que algún veraneante con alma de artista había modelado, y sobre su lomo surcaron durante horas el mar, con gran regocijo por lo insólito del paseo y porque, a causa de los movimientos del animal, tuvieron que agarrarse mucho el uno contra el otro. Otros días volaban montados en dos gaviotas y se saludaban y se lanzaban besos al cruzarse las aves en el aire.

Al declinar el verano llegó el momento de la despedida. A Celestino se le hizo un nudo en la garganta, pero Marlinda supo consolarlo diciéndole que, aunque no la viese, ella estaría pensando en él en su palacio y que antes de darse cuenta ya habría de nuevo niños en la arena levantando castillos y ella volvería al primero que se construyera y allí le estaría aguardando.

En una noche de otoño, un pescador al que invité a una jarra de cerveza en una taberna junto a la lonja, me habló de la sinrazón de Celestino. Y mi natural, proclive a ensoñaciones y cuentos absurdos, me obligó a buscarle. Lo hallé a punto de embarcarse para la traína nocturna y le retuve, contra su deseo al principio, durante el tiempo que tardó en aparejarse el bou. Mentí para atraerme su voluntad y que me abriera su corazón.

- La otra tarde -le dije- una princesa me habló de usted y de si le conocía. Fue en la playa de Levante y casi a la anochecida.

Luego le pregunté si eran ciertos sus amores con aquella dama que yo decía haber visto.

- Tan ciertos como esta mar y este cielo -me dijo con vehemencia-; aunque quizá usted se burle como los otros.

Le aseguré que no, que le tomaba en serio, y le pedí más detalles de aquella relación. Me contó lo que tengo escrito y luego, con un punto de emoción en sus ojos, añadió:

- Pero no lo cuente por ahí; no le creerían.

$\mathrm{Y}$ si lo cuento es porque a veces estoy seguro de que es verdad; o porque me gustaría que lo fuese.

\section{Diálogos en el parque}

El día anterior había sido muy caluroso y las primeras horas de la noche continuaron manteniendo la temperatura. Ahora, próximo ya el 
amanecer, empezaba a correr un poco de aire por entre las frondas del Retiro madrileño. Al otro lado de las rejas y tapias del parque la ciudad estaba sumida en el sueño y, siendo domingo y veraniego el día que se avecinaba, ni tan siquiera circulaban vehículos de trabajadores tempraneros. Miles de pájaros despertaban en setos y enramadas iniciando una algarabía que pronto llenó toda la extensión de los jardines. La brisa agitaba las hojas de los árboles y su rumor, con el piar y los trinos de las aves, parecía formar un misterioso coloquio.

En ese momento el roble de áspero y recio tronco llevaba la voz cantante. Castaños, plátanos de Indias y acacias atendían al viejo compañero atenuando el parloteo de sus follajes.

- Estoy decidido; me marcho. Ya sé que hemos hablado muchas veces de lo mismo y que siempre os habéis burlado de mí. Pero ha llegado el momento. ¿Quién vendrá conmigo?

Fue la acacia la primera en responder.

- ¡Pobre necio! ¿Cómo quieres escapar a tu naturaleza? Somos árboles y nuestro ser nos ata a un pedazo de tierra desde que brota nuestra semilla o prende el esqueje hasta que, antes o después, se nos secan las entrañas. Así fue siempre; así será eternamente. ¿Y tú vas a cambiarlo?

- Es cierto que siempre ha sido así, pero lo que ha de ser en adelante lo podemos decidir nosotros. Nunca ningún árbol intentó moverse, pero si uno lo hiciera, si yo lo lograse, ¿no sería mentira todo lo que hemos creído hasta ahora?

Terció un magnolio en cuyas gruesas ramas una docena de pardillos, algunos, los machos, de rojiza pechera, se revolvían en busca de mosquitos y bullidoras polillas.

- Yo te comprendo, amigo roble y en muchas ocasiones he sentido el mismo ansia de descuajarme. El mundo es grande, enorme, y el nuestro se reduce a lo que cubre nuestra sombra. Sin embargo, eso no es del todo cierto. Tú y yo estamos aquí arraigados, pero no debe cegarnos la egolatría. Cada uno no es sino una parte casi insignificante de nuestra especie. Ese mundo que anhelamos está en realidad recorrido por robles y por magnolios, como lo está por hermanos de todos y cada uno de los ejemplares que pasamos nuestra vida en este parque. Nuestros hermanos llenan la tierra; y nuestros hijos también, porque mis semillas y las tuyas y las de ellos han traspasado estos límites y quizá retoñen al otro lado del mundo.

El roble, en una racha más fuerte de viento, pareció gritar. 
- ¡Mi vida es mía! ¡Allá se vaya la especie y mis padres y mis hijos!, ¡mía, mía y de nadie más! Yo seré lo que yo haga y me llevaré mis solos recuerdos cuando algún día arda en una hoguera o mis restos adornen cualquier obra de los hombres. De nada me vale saber que otros están donde yo quisiera. Incluso me incita más el pensarlo. En noches como ésta he tenido largas conversaciones, a través del viento y de los amistosos y parlanchines mirlos, con algunos árboles del Jardín Botánico, nuestros vecinos. Ellos no nacieron aquí como nosotros; muchos han surgido a la vida en lugares muy lejanos y viajaron hasta nuestra vecindad. La ceiba y el tulipero y la palmera de Japón y tantos otros me han hablado de sus tierras de origen, de las que unos salieron levantando una cuarta del suelo y otros ya en sazón de sus frutos. Ese mundo con el que yo sueño no es invención mía aunque quizá lo adorne mi ilusión; pero existe, jclaro que existe!; ellos lo han conocido y yo quiero conocerlo también.

- ¡Vana ilusión! -volvió a intervenir la acacia-. Te hablan de algo que perdieron para siempre; su vida es la nuestra, fijos aquí, con un exotismo que los hace, quizá, más apreciados, pero inmóviles como tú o como yo.

Un álamo que esperaba la luz del sol para hacer brillar la plata de sus hojas, tomó la palabra.

- Yo también he hablado con las plantas del Jardín, pero mi charla ha sido sobre todo con las vides de las pérgolas, no con los solemnes e imponentes árboles; las cepas, casi ignoradas, están deseosas por ello de hablar. Una noche otoñal, cuando mis hojas amarilleaban y 'se me iban con cada soplo de brisa y las suyas apenas podían cubrir los racimos preñados de zumo, hablamos de ti y de tus sueños que todos conocemos. Yo te defendí y hasta hice ver que compartía tu deseo de marcha. Las cepas hablaban cansinamente, como agobiadas por el peso de sus frutos. Ellas me dijeron que estabas en un error; salía por su voz la luz de la experiencia y era unánime la opinión de sus sarmientos. «Nosotras, decían, valemos precisamente por estar donde estamos; cada una da su fruto y es lo que es por la tierra en que se enraíza. Aragón, Rioja, Andalucía, Castilla... somos la misma planta, pero por el suelo que nos nutre nadie nos confundirá. Si cambiáramos de lugar dejaríamos de ser nosotras mismas y entonces de qué nos serviría el viaje. Nadie es sino en su tierra con la que forma unidad indisoluble. Cuando todo cambia, nada es seguro ni firme, es cuando adquiere mayor importancia la fijeza de 
nuestras especies; las plantas somos el símbolo de lo perenne, de lo inmutable aunque cambie nuestro aspecto exterior; siempre estaremos en nuestro sitio, para quien quiera buscarnos y hallar a nuestro lado el reposo a tanta mudanza.

Con el alba, el murmullo que llenaba el espacio del Retiro se intensificó y el lenguaje de trinos, gorjeos, piares y entrechocar de hojas se extendió fuera de sus tapias. Ahora participaban del coloquio, nacido a orillas del lago de los cisnes, todas las plantas del gran parque y también los árboles de bulevares, glorietas y jardincillos. La discusión se animaba con el aviso del sol. Castaños, tilos, chopos callejeros se unían al diálogo; surgían por doquier partidarios de una u otra postura. Entre hermanos de la misma especie había enfrentamientos. Algunos árboles constreñidos por su alcorque porfiaban casi con violencia a favor de la huida; otros, a cuya sombra se acogerían dentro de unas horas hombres cansados, mujeres afanosas y niños juguetones, renunciaban a un sueño imposible por la callada compañía a aquellos seres que, sin reconocerlo, les necesitaban.

En la orilla del estanque una secular higuera que apoyaba su ya casi estéril estructura en un montón de rocalla alzó su voz trémula.

- ¡Vete, vete! No te dejes convencer por los que no tienen tu ánimo. ¡Ay, si yo hubiese cedido a ese impulso cuando tenía fuerzas! Pero ahora ya ves: sólo corren por mi interior unas tenues gotas de vida y apenas sirvo de sostén a esta yedra que tiñe de verde ajeno mi viejo y seco tronco. Vete de una vez, rompe con todo, recorre el mundo y cuando vuelvas, feliz o amargado, si aún me encuentras, cuéntame cómo es y quizá algo reviva en lo más profundo de mis raíces.

Amanece en el Retiro... El madrugador visitante cree oír palabras sueltas entre el frondoso techo vegetal que tiene sobre su cabeza. Un petirrojo salta en corto vuelo de un árbol a otro; un mirlo, indiferente al hombre, sigue terne su canto agudo; los primeros rayos de sol cruzan las enramadas y dibujan en el suelo, a los pies del paseante, extraños y cambiantes signos. Amanece en el Retiro.

\section{La extraña Cofradía}

(Primer Premio XIII Concurso TRIBUNA MÉDICA de Cuentos)

Don Salvador Manjón y Bosch, cincuenta y tres años de edad, magistrado juez de la Audiencia Provincial, es miembro de la Cofradía de la Buena Muerte desde hace seis años y en las últimas elecciones ha sido 
nombrado Hermano Mayor por una inmensa diferencia de votos, incluido el suyo propio, sobre el otro candidato. Don Salvador mira con impaciencia el gran reloj de péndulo que hay frente a él en su despacho. Tempus fugit, proclama en su esfera con letra gótica. Mientras el secretario va leyendo parsimoniosamente los expedientes y otros documentos que Su Señoría ha de firmar inexcusablemente esta tarde, Don Salvador tamborilea con los dedos sobre el brazo de su butaca.

- Hala, Mariano, abrevie; sáltese usted los prolegómenos y léame sólo el meollo que esta tarde tengo un poco de prisa.

Al terminar, Don Salvador sale del edificio de la Audiencia como una exhalación, sin contestar a los saludos de los ujieres y de los dos o tres abogados que se cruzan con él por los anchos pasillos. Coge su coche del aparcamiento reservado y se dirige hacia una de las calles en que termina el casco viejo de la ciudad y empieza el ensanche. Estaciona el vehículo y permanece en su interior hasta que ve aproximarse un taxi por el extremo de la calle; sólo entonces se apea, se sube las solapas del abrigo y hace un gesto para detenerlo mientras echa la llave a su coche. Da al conductor una dirección y se arrebuja en el asiento sin aceptar los varios intentos del taxista por entablar palique. Llegado al fin de la carrera deja que el taxi desaparezca de su vista para iniciar a pie el último tramo de su recorrido hasta un callejón donde hay varias puertas todas iguales; llama a la tercera en la que se abre un ventanuco por el que asoma los ojos y la nariz un individuo medio bizco que, una vez comprobada la identidad del recién llegado, le franquea la entrada.

Don Ángel de la Gándara Pérez, sesenta años recién estrenados, médico de la plaza desde que sustituyó a su padre, es uno de los fundadores de la Cofradía de la Buena Muerte y ha sido su Hermano Mayor durante los tres períodos que permiten los estatutos; ahora ha pasado a ser vocal de honor en la junta directiva. A la hora en que debía marcharse aún le quedan en la sala de espera dos pacientes; uno de ellos, además, es Leocadio, un hipocondríaco que vendrá a contarle los últimos síntomas que se ha notado desde la anterior visita hace cuatro días y que, de seguro, coincidirán con los que padece algún personaje popular que los haya narrado con pelos y señales en las revistas del corazón. Menos de veinte minutos no le va a costar echar de allí a Leocadio con dos píldoras y unas tisanas tras convencerle a medias de que lo suyo no es de operar. Esta tarde Don Ángel llegará con retraso a la reunión y habrá perdido casi media hora de disfrute.

Don Ramón Sanchís Ortega, cincuenta y nueve años bastante mal llevados, esa es la verdad, dueño de La llave de oro, ferretería, material 
de bricolaje y jardin, sueña desde hace quince años en que ingresó en la Cofradía de la Buena Muerte con llegar a ser Hermano Mayor y en las elecciones pasadas pensó que podía conseguirlo, pero vio con dolor cómo era elegido Don Salvador Manjón y Bosch, el magistrado. Don Ramón Sanchís no es hombre rencoroso pero sí perseverante y está dispuesto dentro de cuatro años a realizar una campaña con todos los medios y a vencer en las urnas a Don Salvador o a quien se presente. Hoy le ha dicho a Bartolo, el dependiente, que tiene que irse antes del cierre para arreglar unas cosillas con el concesionario de las segadoras y que se ocupe él, Bartolo, de cerrar el establecimiento y dejar el arqueo para mañana. Bartolo dice que bueno, que lo hará como los otros días en que el jefe sale de estampida sobre la misma hora.

- Oye, ¿a ti te importa que yo me vaya, o qué?

- No, señor, a mí qué me va a importar.

Don Primitivo Artiñano Artiñano, a dos meses de cumplir los setenta años, canónigo penitencial de la Santa Iglesia Catedral, es, con Don Ángel, de los fundadores de la Cofradía de la Buena Muerte. Aunque la Cofradía se define como apolítica y aconfesional, a Don Primitivo se le nombró capellán honorífico sin demasiadas reticencias entre los cofrades. Don Primitivo, como Don Ángel, tiene sus clientes especialmente insoportables, y en su caso es Doña Angelina, la esposa de Don Ramón, el de La llave de oro. La hipocondría espiritual no es menos fatigosa que la física y se la suele llamar escrúpulos de conciencia. Cuando hoy Don Primitivo ha visto desde su confesonario acercarse por la nave de la Catedral a Doña Angelina, le han entrado deseos de desaparecer y casi ha renegado de sus obligaciones sacerdotales. Al final ha podido liberarse de ella en poco más de un cuarto de hora por el expeditivo sistema de indicarle, ante la primera duda de la penitente, que creía que no había hecho bien el examen de conciencia y que sería mejor dejar la confesión para el día siguiente, no sin asegurarle que, en su caso y hasta ese momento, era suficiente el propósito de enmienda para estar en gracia.

Don Roque Zúñiga Santiago, cincuenta años, jefe del negociado de epizootias en la delegación provincial del Ministerio de Agricultura, Pesca y Alimentación, entró en la Cofradía de la Buena Muerte hace sólo dos años, casi nada más llegar destinado desde otra provincia de menor categoría. Cuando Don Roque llegó aquí traía instrucciones de un amigo del Ministerio, miembro de la Cofradía del Buen Aire en su ciudad de origen, para ponerse en contacto con los de la Buena Muerte. Así, una mañana se dirigió a la Audiencia, preguntó por el Señor Magistrado Don Salvador Manjón y cuando estuvo frente a él, aunque rodeado de otras 
seis o siete personas cuya filiación desconocía, se llevó a los labios los dedos índice y corazón de la mano izquierda ligeramente abiertos y vio enseguida cómo Don Salvador le devolvía el mismo gesto; luego hablaron breves momentos de algún tema banal y recibió una esquela con una dirección. La misma a la que ahora iba por calles secundarias, echando de vez en vez la vista atrás y deteniéndose ante cualquier escaparate si notaba que alguien iba en pos suyo durante más de dos manzanas.

Don Indalecio Martín Agreda, cuarenta años, catedrático de literatura, Área de Lenguaje, en el Instituto Sancho el Fuerte, es miembro de la Cofradía de la Buena Muerte desde hace cinco años y actualmente tesorero de la institución. Don Indalecio, durante las reuniones, suele tirarle puyas a Don Primitivo, el capellán honorario, dándoselas de agnóstico y alardeando de que su padre lo educó en los principios de la Institución Libre de Enseñanza. Alguna vez Don Primitivo entra al trapo, y hasta sospecha que Don Indalecio tiene dejes o algo más de masón, pero nunca ha llegado la sangre al río y siempre está al quite algún que otro cofrade que cambia la conversación hacia temas menos conflictivos: la subida del catastro, la reciente faena de un Curro ante un Albaserrada, el programa de festejos para San Atilano o incluso, aunque Don Primitivo tuerza el gesto, las piernas y el antifonario de una presentadora de televisión.

Esta tarde, como cada lunes, miércoles o viernes, hay reunión en la Cofradía de la Buena Muerte. Preside Don Salvador y están presentes todos sus miembros, treinta y dos, excepto Don Ángel de la Gándara que llega al rato de iniciarse y con un humor de perros, mascullando no sé qué del número de imbéciles que hay en el mundo.

La Cofradía de la Buena Muerte tiene su sede en un amplio salón abovedado en el que se distribuyen butacas de muy distinta condición y procedencia; algunas desvencijadas y enseñando sus tripas de alambre y estopa o goma espuma; otras de plástico imitando piel, cuarteadas y semidescoloridas; unas pocas de piel auténtica y hasta alguna con orejas y acompañada de un escabel a juego. Cada asiento tiene su dueño al iniciarse la sesión, aunque en su transcurso los asistentes cambian de lugar sin protocolo según se van estableciendo los corrillos de tertulia.

El Hermano Mayor da la orden de que se cierren las puertas, comprueba, como es su obligación, que todos los presentes tienen derecho a estar allí por ser miembros de la Cofradía y que no se ha introducido ningún extraño a menos que haya sido presentado por un miembro y aceptado por unanimidad. Una vez cumplidos estos trámites, no sólo rituales sino necesarios para la supervivencia de la Cofradía, el Hermano Mayor saca de su bolsillo un llavín camuflado entre otros diez de distintos usos y con él abre el candado de un viejo arcón de roble con herrajes 
que se encuentra en un rincón de la sala. Los cofrades se agitan nerviosos en sus butacas y estiran el cuello queriendo entrar con los ojos en el gran baúl. Al momento, el Hermano Mayor, hoy Don Salvador Manjón y Bosch, extrae varias cajetillas de tabaco negro y rubio emboquillado, unos puros de diferente vitola, una caja metálica redonda de aromático tabaco de hebra a la que va sujeta con un bramante una pipa de brezo, y una caja de cerillas grande, de esas que se usan en las cocinas. Cada cofrade recibe su ración según sus gustos particulares, la enciende y durante unos minutos no se oye en aquel sitio más que un tenue crepitar de hojas de tabaco ardiendo, mientras el aire se llena de un espeso, azulado, delicioso y embriagador humo. La Cofradía de la Buena Muerte, sociedad secreta de fumadores, está en sesión plenaria. 